\title{
POLLEN MORPHOLOGY OF THE DICHAPETALACEAE WITH SPECIAL REFERENCE TO EVOLUTIONARY TRENDS AND MUTUAL RELATIONSHIPS OF POLLEN TYPES
}

\author{
W. PUNT
}

Laboratory of Palaeobotany and Palynology, State University, Utrecht (The Netherlands) (Accepted for publication June 6, 1974)

\begin{abstract}
Punt, W., 1975. Pollen morphology of the Dichapetalaceae with special reference to evolutionary trends and mutual relationships of pollen types. Rev. Palaeobot. Palynol., 19: 1-97.

Pollen grains of all three genera of Dichapetalaceae (Dichapetalum, Stephanopodium and Tapura) comprising about 150 species have been studied. Twenty-nine pollen types were recognized and the family has to be considered eurypalynous. A key to the pollen types is added. Based on evolutionary trends it was possible to give a scheme to the mutual relationships of the pollen types. It is concluded that the centre of origin of the family may be Africa. It was not possible to point to distinct relationships with other families on pollenmorphological data alone.
\end{abstract}

\section{INTRODUCTION}

The family Dichapetalaceae has recently been revised by three different taxonomists. The African species, which are the majority, were monographically studied by Dr. F. J. Breteler (Wageningen). Dr. P. Leenhouts (Leiden) studied the Asian representatives for the Flora Malesiana and the American taxa were treated by Dr. G. T. Prance (New York). Because of these recent monographs the author was able to study correctly identified material and to discuss taxonomic problems.

The investigation was undertaken not only to elucidate the taxonomy of the Dichapetalaceae, but also to give general information on variation and possible evolution of pollen grains in the family.

At the start of the present study little was known about the pollen grains of the Dichapetalaceae. Erdtman (1952, p.145) describes several species, but the descriptions were too short and the drawings too small to give a good idea of the variability of features within the family. Subsequently, papers have dealt only incidentally with pollen morphology in the Dichapetalaceae (Hallé and Heine, 1967; Lobreau, 1969; Archangelsky, 1971). Among these publications the paper by Lobreau is of some interest. She gives two examples from the Dichapetalaceae (Dichapetalum nigrescens and Tapura 
neglecta) and a short discussion of the place of the family in the Angiospermae. She suggests a weak resemblance to some members of the Icacinaceae and a relation to certain Euphorbiaceae (for comment see p. 59).

\section{MATERIALS AND METHODS}

\section{Materials}

Most of the material was supplied by Dr. F. J. Breteler and a smaller part was obtained from Dr. P. Leenhouts and Dr. G. T. Prance. The material was identified by these three taxonomists. All slides have been prepared from herbarium sheets which were obtained from the following herbaria: B, BM, BREM, C, COI, E, EA, FAI, GOET, HBG, IRSC, K, L, LISC, LISU, M, NY, P, RE, U, UPS, W, WAG, WU, Z. The abbreviations follow those published in the Index Herbariorum, part I (ed. Lanjouw and Stafleu, 1964).

An attempt has been made to examine pollen grains of all accepted taxa in the family, but this has only partly been successful because of the lack of good flowering material and the rarity of the species.

In America the species of Stephanopodium seem to be very sparsely represented in the vegetation. Several species have been described by different authors, but the material of only two species out of nine, could be examined. Also, the species of Dichapetalum and Tapura are not abundant in the American flora, nevertheless sufficient material of most taxa was available.

The Asian taxa gave less difficulties and the majority of the species has been studied. Out of sixteen species, material of the following four was not available for examination: $D$. sordidum (J. D. Hooker) Leenhouts, $D$. platyphyllum Merrill, $D$. tenerum Leenhouts and D. tenuifolium (King) Engler.

The African taxa were best represented and it was possible to examine pollen grains of all species of Dichapetalum and Tapura from this continent.

\section{Methods}

The pollen grains were prepared using the acetolysis method as described by Reitsma (1969). The pollen grains were mounted in glycerine-jelly and afterwards covered with a cover slip supported by two granules of modelling clay and sealed with parafin wax (Reitsma, 1969).

Descriptions were made with a Leitz light microscope equipped with a Plan Apochromatic objective $\times 100 / 1.32$ and Periplan $\times 10$ eye-pieces. Five measurements of pollen size ( $\mathrm{P}$ and $\mathrm{E}$ ) were generally made from each specimen. As the size of a pollen grain is highly dependent on the preparation method followed (Reitsma, 1969), measurements have not been emphasized and their value should only be considered as relative.

The photomicrographs were taken with the use of a Plan Apochromatic 
objective $\times 90 / 1.40$ with a Leitz Orthomat camera and an interference green filter.

For Scanning Electron Microscopy (SEM) acetolysed pollen grains were coated with carbon and gold.

Some pollen grains have been sectioned, according to the method as described by Leins (1968), with the aid of a Leitz microtome which enables the cutting of section up to $1 \mu$ thin.

\section{Terminology}

Terminology used in this paper is based mainly on the system proposed by Reitsma (1970a). In addition to these frequently used terms some special features occurring in the Dichapetalaceae need further explanation.

Cluster: Like most authors, the present author has chosen the pollen type as the base of his classification of pollen grains. A definition of this unit has been given in a previous paper (Punt, 1971). In the same publication a definition of the term pollen group has been proposed. Sometimes it is convenient to express resemblances between pollen types by a term. Thus several pollen types together having one or more characters in common can be assembled in clusters. A more precise definition of this unit is as follows: A cluster comprises two or more pollen types which have one or more characters in common and which are pollenmorphologically related.

Inaperturate: According to the definitions given by Reitsma (1969), inaperturate pollen grains lack ectoapertures. However, endoapertures may be present, and consequently, if the endoapertures are zonately arranged, polarity can be established.

Interrupted muri: In many reticulate pollen grains the apocolpia show irregularities in the reticulum where the normal network of muri breaks down to a certain degree, such interruptions appearing not to form any recognizable pattern. The extent of this feature is variable; in some cases an area may be left bare of muri, whereas in others scattered, unconnected lengths of muri may occur in a random arrangement. All these variations are described by the term interrupted muri (Plate XX, 2, 3,6)*.

Subacute: In many Dichapetalaceae types the outline in polar view is triangular. Some of them show sides which seem to form a sharp angle. At the very ends, however, the angle is slightly rounded, thus making an obtuse point (Plate XX, 3). For this latter feature the term subacute has been used.

Sunken poles: Several types show in the outline of the equatorial view a distinctly concave long side, which is situated at the polar side. This concavity is due to the sunken position of the apocolpium. As this remarkable feature is most distinctly visible in the outline of the equatorial view, this latter characteristic is mentioned under the section Outlines.

*For Plates see pp. 67-95. 
SPECIMENS INVESTIGATED (Figures in square brackets refer to the pollen types)

Dichapetalum Thouars

D. acuminatum De Wildeman - Gabon: Hallé 3963 (WAG); Zaire: Laurent 1500 (BR), Louis 6339 (BR), Louis 10.558 (PRE) [9].

D. affine (Planchon ex Bentham) Breteler - Cameroun: Leeuwenberg 5631 (WAG), De Wilde 2748 (WAG) [16].

D. albidum (Chevalier ex Pellegrin) - Ivory Coast: Oldeman 18 (WAG) [1].

D. altescandens Engler - Gabon: Hallé 1959 (WAG), Le Testu 7183 (WAG) [9].

D. angolense Chodat - Angola: Gossweiler 7677 (COI); Cameroun: Zenker 3265 (PRE), Zenker und Staudt 46 (Z); Liberia: Dinklage 1970 (B); Zaire: Louis 255 (BR), Reygaert 1045 (BR) [1].

D. arachnoideum Breteler - Gabon: Pobéquin $91(\mathrm{P})[2]$.

D. arenarium Breteler - Tanzania: Hansen 486 (WAG), Schlieben 2651 (B) [3].

D. axillore Woodson - Costa Rica: A. Smith 971 (NY) [12].

D. bangii (F. Didrichs) Engler - Cameroun: Zenker 1384 (GOET); Rhodesia: Fries 727 (UPS); Spanish Guinea: Tessman 161 (K); Zaire: Bequaert 6514 (BR), Gorbatoff 253 (BR), C. Smith s.n. (C), Thonner 148 (BR) [2].

D. barbatum Breteler - Cameroun: Bos 4318 (WAG) [1].

D. barbosae Torre - Moçambique: Barbosa 2085 (LISC, TYPE) [3].

D. barteri Engler - Nigeria: Barter 1781 (P, ISOTYPUS) [4].

D. aff. barteri - Zaire: Kuasa 20 (WAG) [4].

D. beilschmidioides Breteler - Cameroun: Bos 4318 (WAG) [9].

D. bocageanum Henriques - Principe Is.: Mann s.n.: Anno $1861(\mathrm{~K})$; Sao Tomé: Quintas 1077 (COI) [1].

D. bodyi De Wildeman - Zaire: Lebrun 6637 (BR) [11].

D. bojeri (Tulasne) Engler - Madagascar: Cons. Rés. Nat. Madagascar 3006 (P), Humbert et Perrier 2358 (B) [13].

D. braunii Engler - Tanzania: Warnecke in Herb. Amani 606 (PRE), Schlieben 5196 (Z) [4]

D. brazzae Pellegrin - Cameroun: Bates 1194 (BM); Congo (Brazzaville): Koechlin 6029 (IRSC), Trochain 11385 (P); Zaire: Achten 119b (BR), Bequaert 6849 (BR) [1].

$D$. cazengoense Exell - Angola: Gossweiler 1641 (COI) [4].

D. chalotii Pellegrin - Congo (Brazzaville): Koechlin 411 (P), Thollon 553 (P, TYPE); Gabon: Breteler 7000 (WAG); Zaire: Madoux 93 (PRE) [21].

D. chlorinum (Tulasne) Engler - Madagascar: Perrier de la Bâthie 14956 (P) [5].

$D$. choristilum Engler - Cameroun: Leeuwenberg 5631 (WAG), Leeuwenberg 5595 (WAG) [6].

D. cinereo-viride Engler - Cameroun: Zenker 2900 (W, ISOTYPE) [11].

D. cinereum Engler - Cameroun: Zenker 745 (BREM); Gabon: Le Testu 7656 (WAG), Le Testu 8239 (WAG), Le Testu 8338 (WAG) [1].

D. congoense Engler et Ruhland - Gabon: Breteler 6747 (WAG); Zaire: Louis 6372 (COI) [11].

D. contractum Engler - Angola: Gossweiler 13578 (B); Cameroun: J. Felix 3202 (P); Zaire: Bequaert 3093 (BR) [11].

D. corrugatum Exell - Congo (Brazzaville): Bouquet 507 (P) [11].

D. costatum Breteler - Cameroun: Binuyo and Daramola, F. H. I. 35574 (WAG); Gabon: Klaine 3300 (P); Ivory Coast: Leeuwenberg 3739 (WAG) [1].

D. crassifolium Chodat - Gabon: Klaine 1911 (WAG), Le Testu 2096 (WAG); Le Testu 6479 (P); Liberia: Jansen 890 (WAG); Nigeria: Adesbuyi, F. H. I. 43582 (K); Zaire: Mildbread 2203 (BM) [7].

D. cuneifolium Engler - Angola: Marques 212 (LISU) [11].

D. cymosum (Hooker) Engler - Moçambique: De Carvalho s.n. (COI) [4] .

D. cymulosum (Olivier) Engler - Cameroun: Bos and Breteler 3066 (WAG); Gabon: Le Testu 2081 (WAG) [11]. 
D. deflexum (Klotzsch) Engler - Moçambique: De Carvalho s.n. (COI) [1] .

D. deweurei De Wildeman et Durand - Angola: Dacremont 213 (COI); Cameroun: Zenker 1978 (WU); Congo (Brazzaville): Farron 4804 (P); Gabon: Breteler 6602 (WAG), Klaine 210 (WAG), Klaine 3353 (WAG); Zaire: Carrington 87 (WAG) [1].

D. dictyospermum Breteler - Ivory Coast: Oldeman 962 (WAG) [11].

D. echinulatum Exell - Cameroun: Mildbread 7816 (K); Gabon: Breteler 6694 (WAG), Le Testu 5910 (P) [7].

D. edule Engler - Tanzania: Eggeling 6749 (EA), Gillman 1126 (EA), Gillman 1367 (EA), Schlieben 5195 (Z) [6].

D. eickii Ruhland - Tanzania: Drummond and Hemsley 2591 (B) [11].

D. filicaule Breteler - Ivory Coast: Geerling and Bokdam 830 (WAG) [11].

D. froesii Prance - Brasil: Froes 22325 (U); Colombia: Cuatrecasas 8975 (NY) [12].

D. fructuosum Hiern - Gabon: Le Testu 9526 (WAG); Nigeria: Chizea, FHI 24486 (FHI); Zaire: Bequaert 2166 (WAG, ISOTYPE), Jans 286 (BR), Troupin 4046 (WAG) [2].

D. gabonense Engler - Cameroun: Bos en Breteler 3100 (WAG), Letouzey 9828 (WAG); Gabon: Soyaux 391 (Z), Le Testu 7169 (WAG) [21].

D. gelonioides (Roxburgh) Engler ssp. andamanicum (King) Leenhouts - Andamans: King's Collector 316 (L, SYNTYPE) [8].

D. gelonioides (Roxburgh) Engler ssp. gelonioides - Indonesia (Sumatra): Lörzing 16502 (L); Thailand: Kerr 21346 (L), Kerr 16902 (L), Put 3732 (L), Put 3746 (L), Thaworn 47 (L) [8]

D. gelonioides (Roxburgh) Engler ssp. pilosum Leenhouts - Indonesia (Borneo): Endert 2784 (L); Malaya: Whitmore 0101 (L); Philippines: Frake 593 (L); Sandakan: SAN 37555 (L), SAN 50532 (L), SAN 64730 (L) [8].

D. gelonioides (Roxburgh) Engler ssp. sumatranum (Miquel) Leenhouts - Indonesia (Sumatra): Rahmat si Toroes 807 (L), Forbes 3149 (L); Malaya: Purseglove P. 5526 (L); Sandakan: J. et M.S. Clemens 26862 (L) [8].

D. gelonioides (Roxburgh) Engler ssp. tuberculatum Leenhouts - Philippines: Elmer 12121, Elmer 12211 (L), Elmer 12284 (L) [8].

D. germainii Hauman - Zaire: Lebrun 5919 (BR), Louis 3175 (BR) [11].

D. gillardinii Hauman - Zaire: Gillardin 232 (BR, TYPE) [2].

D. gillettii De Wildeman - Zaire: Bequaert 844 (BR) [9].

D. glomeratum Engler - Cameroun: Bos 6527 (WAG); Gabon: Klaine 1238 (P); Spanish Guinea: Tessman 1008 (K); Zaire: Germain 8585 (LISC); Louis 9533 (Z) [11].

D. grandiflorum Ridley - Sandakan: SAN 30688 (L) [10].

D. griffithii (Hooker) Engler - Malaya: K.L. 1804 (L) [14].

D. helferianum (Kurz) Pierre - Thailand: Kerr 16635 (L), Put 832 (L) [8].

D. heudelotii (Planchon ex Olivier) Baillon-Cameroun: Bos 4809 (WAG), Conrau 106 (BM), Ledermann 1092 (BM), Preuss 1275 (M), Zenker 3874 (Z); Gabon: Klaine 1473 (WAG); Ghana: Vigne 1635 (K); Sierra Leone: Mann 800 (P, SYNTYPE), Scott-Elliot 5526 (BM); Zaire: Schweinfurth $3152(\mathrm{P})$, Dewèvre $777(\mathrm{BR})$ [11]

D. hispidum (Olivier) Baillon - Gabon: Breteler 6526 (WAG), Mann 1821 (K) [11].

D. humbertii Descoings - Madagascar: Capuron 8507 (P), Decary 5538 (WAG) [21].

D. insigne Engler - Gabon: Hallé 3756 (P) [11]

D. integripetalum Engler - Cameroun: Zenker 3707 (Z) [4].

D. latifolium Baillon - Bolivia: Buchtien 1718 (NY); Peru: Klug 496 (NY) [12].

D. laurocerasus (Planchon) Engler - Malaya: Maingay 2279 (L, LECTOTYPE) [14 ].

D. leucosia (Sprengal) Engler - Madagascar: Decary 4167 (PRE) [13].

D. liberiae Engler et Dinklage - Ivory Coast: Breteler 5327 (WAG); Liberia: Dinklage 2722 (B), Jansen 1204 (WAG) [1].

D. librevillense Pellegrin - Gabon: Breteler 6840 (WAG), Klaine 2377 (WAG) [1].

D. lofaense Breteler - Liberia: Van Meer 27 (WAG) [1].

D. longipetalum (Turczaninov) Engler - Hainan: Lei C.I. 100 (L); Malaya: Salleh S.F.N. 31979 (L); Vietnam: Poilane 10133 (L), Poilane 10136, Balansa 3328 (L) [14]. 
D. longitubulosum Engler - Cameroun: Dinklage 796 (HBG) [11].

D. lujaei De Wildeman et Durand - Angola: Gossweiler 6073 (LISU); Gabon: Le Testu 2004 (P); Zaire: Bequaert 609 (BR), Dewèvre 10048 (BR), Schlechter 12582 (Z) [2] .

D. macrocarpum Engler - Tanzania: Schlieben 5356 (M), Schlieben 5832 (HBG) [15].

D. madagascariense Poiret - Angola: Gossweiler 585 (BM), Gossweiler 6279 (COI), Goss weiler 6907 (LISU); Cameroun: Dinklage 1094 (HBG), Zenker 3890 (Z); Congo (Brazzaville): Trochain 8508 (IRSC); Fernando Po: Mann 16 (W); Gabon: Breteler 5788 (WAG), Breteler 6998 (WAG), Le Testu 8470 (P), Le Testu 9229 (WAG); Guinea: Adam 4027 (WAG); Ivory Coast: Leeuwenberg 2768 (L), Den Outer en Versteegh 383 (WAG); Kenya: Verdcourt 1899 (EA); Liberia: Bos 2219 (WAG); Madagascar: Cons. Rés. Nat. Madagascar 7366 (P), Perrier de la Bâthie 408 (P); Nigeria: Van Eynatten 1247 (WAG), Jones and Onochie 17347 (B); Thoms on 79 (E); Rép. Centre-Afrique: Le Testu s.n. (WAG); Corbisier-Baland 1296 (BR); Uganda: Bagshawe 595 (BM); Zaire: Bequaert 2174 (BR), Donis 1966 (WAG), Dubois 1021 (BR), Gilbert 2170 (LISC), Louis 1014 (BR), Louis 9339 (BR), Malchair 238 (BR), Mildbread 3301 (B), Mildbread 3690 (HBG), Mortehan 55 (BR), Pierlot 3153 (WAG), Pynaert 1750 (BR), Reygaert 820 (BR), Sapin s.n. (BR), Vaughan 1444 (EA) [21].

D. madagascariense Poiret var. beniense (Engler) Breteler - Zaire: Gutzweiler 2195 (WAG), Mildbread 2200 (BM, TYPE) [21].

D. minutiflorum Engler - Cameroun: Bos 4514 (WAG) [11].

D. mombuttense Engler - Congo (Brazzaville): Sitha $736(\mathrm{P})[16]$.

D. montanum Breteler - Cameroun: W. de Wilde 1375 (WAG) [11].

D. mossambicense (Klotzsch) Engler - Kenya: Drummond and Hemsley 3828 (B); Moçambique: Barbosa 2264 (LISC) [1].

D. multiflorum (Tulasne) Descoings - Madagascar: Cons. Rés. Nat. Madagascar 3245 (P), Perrier de la Bâthie 6214 (P), Rakotozapy 282 (P) [21].

D. mundense Engler - Cameroun: Breteler 2054 (WAG), Breteler 2745 (W AG); Zaire: Louis 1408 (BR) [17].

D. ndongense Engler - Angola: Gossweiler 6256 (LISU), Congo (Brazzaville): Sitha 1891 (WAG); Ivory Coast: Breteler 5829 (WAG), Breteler 5841 (WAG); Zaire: Pynaert 171 (WAG) [11].

D. nigrescens (Tulasne) Baillon - Madagascar: Hildebrandt 3284 (W) [13].

D. nyangense Pellegrin - Gabon: Le Testu 2121 (WAG) [2].

D. obanense E.G. Baker - Nigeria: Talbot 1627 (Z) [21].

D. oblongum (J. D. Hooker ex Bentham) Engler - Cameroun: Zenker 4069 (M) [11].

D. odoratum Baillon - Brasil: Krukoff 8077 (NY) [12].

D. oleifolium (Baker) Descoings - Madagascar: Perrier de la Bâthie 13212 (P) [13].

D. oliganthum Breteler - Cameroun: Bos 4103 (WAG) [11].

D. pachypus (Tulasne) Engler - Madagascar: Humbert 3600 (B) [13].

D. pallidinervum De Wildeman - Zaire: Vanderijst 10899 (BR) [11].

D. pallidum (Olivier) Engler - Cameroun: Zenker 2451 (COI); Ivory Coast: Leeuwenberg 3771 (WAG), Leeuwenberg 4549 (WAG); Liberia: De Wilde en Voorhoeve 3801 (WAG); Nigeria: Barter 3299 (K) [11].

D. papuanum (Beccari) Boerlage - Indonesia (Amboina): Merrill PI. Rumph. Amboinense 602 (L); New Guinea: Carr 12785 (L), Docters van Leeuwen 10606 (L); Solomon Is.: B.S.I.P. 11802 (L) [18].

D. parvifolium Engler - Cameroun: Leeuwenberg 6240(WAG); Spanish Guinea: Tessman $1007(\mathrm{~K})[19]$.

D. aff. parvifolium Engler - Angola: Gossweiler 8986 (K) [19].

D. pauper Rizzini - Brasil: Froes 22493 (U) [12].

D. pedicellatum Krause - Zaire: Gillet 2269 (BR) [9].

D. pedunculatum (Decandolle) Baillon - British Guyana: De la Cruz 1596 (NY); Suriname: Lindeman 4652 (U) [12].

D. perrieri Descoings - Madagascar: Perrier de la Bâthie 6344 (P) [13].

D. pierrei Pellegrin - Gabon: Le Testu 7248 (WAG) [16]. 
D. pulchrum Breteler - Cameroun: Zenker s.n. (P) [11].

D. reticulatum Engler - Cameroun: Zenker 752 (WU) [9].

D. rhodesicum Sprague et Hutchinson - Rhodesia: Allen 234 (K) [2].

D. rudatisii Engler - Cameroun: Bos 3255 (WAG), Leeuwenberg 5230 (WAG) [16].

D. rugosum (Vahl) Prance - Brasil: Froes 30175 (U), N. T. Silva 59726 (U) [12].

D. ruhlandii Engler - Zanzibar: Sacleux 1875 (P) [2].

D. sankuruense De Wildeman - Zaire: Sapin s.n. (BR, TYPE) [23].

D. sessiliflorum Leenhouts - New Guinea: Frodin N. G. F. 26320 (L); Solomon Is.: B.S.I.P. 17224 (L) [18].

D. setosum Leenhouts - Serawak: Benangak Bubeng S. 26106 (L), Haron S. 21385 (L) [10].

D. spruceanum Baillon - Peru: Klug 4306 (U) [12].

D. staudtii Engler - Cameroun: Bates 1761 (WAG); Gabon: Le Testu 8397 (WAG) [11].

D. steenisii Leenhouts - Indonesia (Borneo): Kostermans 21575 (L); (Natuna Is.): Van Steenis $1184(\mathrm{~L})[10]$.

D. stuhlmannii Engler - Tanzania: Schlieben 5344 (B), Stuhlmann 7145 (K, TYPE); Zaire: Lebrun 5562 (BR), Michelson 961 [2].

D. subauriculatum (Olivier) Engler - Nigeria: Onochie FHI 36307 (K), Okafor FHI $36270(\mathrm{~K})[11]$.

D. thollonii Pellegrin - Congo (Brazzaville): Thollon 512 bis (P, TYPE); Gabon: Breteler 6998 (WAG) [20].

D. timoriense (Decandolle) Boerlage - Indonesia (Borneo): Teysmann 21365 (L), Van Niel 4387 (L); (Celebes): Elbert 3291 (L); (Java): Backer 17949 (L), Van Hasselt s.n. (L), s.c., s.n., herb. no. 899.255-46 (L); (Sumbawa): Sujarto 51 (L); Malaya:

Griffith 2170 (L), Maingay 1125 (L), Sinclair 9881 (L); New Guinea: Hartley T. G. H. 10888 (L), Millar N. G. F. 40572 (L); Vandenberg and Katik N. G. F. 42350 (L); Philippines: Celestina and Ramos 23080 (L), Ahern's coll. 3157 (L) [22].

D. tomentosum Engler - Cameroun, Bos 3269 (WAG), Preuss 1103 (P) [11].

D. toxicarium (G. Don) Baillon - Ivory Coast: Breteler 6062 (WAG), Leeuwenberg 3811 (WAG) [16].

D. tricapsulare (Blanco) Merrill - Philippines: Wenzel 1282 (L) [18].

D. ugandense Moss - Uganda: Dümmer 2445 [1].

D. umbellatum Chodat - Gabon: Le Testu 7714 (WAG) [9].

D. unguiculatum Engler - Zaire: Mildbread 3246 (BM), Pynaert 1418 (BR) [1].

D. virchowii (O. Hof fmann et Hildebrandt) Engler - Madagascar: Hildebrandt 3193 (GOET, TYPE) [13].

D. vitiense (Seemann) Engler - Fiji Is.: Smith 6504 (L) [18].

D. vondrozanum Descoings - Madagascar: Decary 5430 (P) [13].

D. whitei Torre - Zambia: White 3364 (PRE) [11].

D. zenkeri Engler - Cameroun: Binuyo and Daramola FHI 35557 (WAG), Bos 6240 (WAG), Mildbread 3913 (HBG), Zenker 659 (COI), Zenker 4344 (E), Zenker und Staudt 243 (GOET); Congo (Brazzaville): Sitha 2004 (WAG); Gabon: Le Testu 7228 (WAG), Le Testu 7615 (WAG), Le Testu 8526 (WAG), Le Testu 8712 (WAG); Kenya: Dale 3862 (B), Graham 1740 (EA), Graham 2132 (PRE); Nigeria: Talbot 1631 (Z); Zaire: Gutzweiler 2460 (P), Lebrun 5773 (LISC), Louis 11510 (EA) [23].

Stephanopodium Poeppig et Endlichter

S. blanchetianum Baillon - Brasil: Bondar 2459 (NY) [29].

S. cngleri Baillon - Brasil: Schwacke 13386 (P) [29].

\section{Tapura Aublet}

T. acreana (Ule) Rizzini - Brasil: Ule 9524 (L, TYPE); Peru: Schunke 142 (NY) [24].

T. africana Olivier - Gabon: Le Testu 7821 (P) [24]. 
T. amazonica Poeppig et Endlicher - Brasil: Black 55-18129 (U), Ducke 20617 (NY), Ducke 23654 (U), Irwin, Souza and Reis dos Santos 9612 (WAG) [ 24 ].

T. bouquetiana Hallé et Heine - Gabon: Breteler 5740 (WAG) [25].

T. capitulifera Baillon - Suriname: B.W. 4525 (U) [24].

T. coriacea Macbride - Peru: Klug 586 (NY) [26].

T. cubensis (Poeppig et Endlicher) Grisebach - Cuba: Britton and Wilson 15607 (NY), Léon and Seifriz $18226(\mathrm{GH})$ [24].

T. fischeri Engler - Ivory Coast: Geerling en Bokdam 2538 (WAG); Tanzania: Volkens 2170 (E) [24].

T. guianensis Aublet - Brasil: Irwin, Pires and Westra 47934 (U), Prance, Pena, Ramos and Monteiro 2197 (WAG); Suriname: Lindeman 4801 (U) [24].

T. ivorensis Breteler - Ivory Coast: Breteler 5955 (WAG, TYPE), Breteler 5964 (WAG) [27].

T. juliani Macbride - Peru: Klug 2010 (NY, TYPE) [28].

T. juruana (Ule) Rizzini - Brasil: Ducke 35409 (U), Krukoff 6160 (NY), Ule 5172 (L, TYPE) [24].

T. lanceolata (Ducke) Rizzini - Brasil: Ducke 325 (NY) [24].

T. latifolia Bentham - Guadeloupe: Duss 3462 (NY); Martinique: Stehlé 5362 (U) [24].

T. le-testui Pellegrin - Gabon: Le Testu 1742 (WAG, ISOTYPE) [24].

T. lujaei De Wildeman et Th. Durand - Zaire: Donis 1543 (PRE) [24].

T. neglecta Hallé et Heine - Gabon: Le Testu 6090 (WAG, ISOTYPE) [24].

T. peruviana Krause - Peru: Y, Mexia 6188 (U) [24].

\section{GENERAL DESCRIPTION}

\section{Pollen class}

The pollen grains in the Dichapetalaceae are usually 3-colporate or inaperturate (without ectoapertures). Inaperturate pollen grains are less common than colporate ones. In a few species the specimens have a small proportion of 4-colporate grains. The occurrence of such "aberrant" pollen grains follows no special pattern and has not been considered of particular significance.

\section{$P / E$ ratio}

The $\mathrm{P} / \mathrm{E}$ ratio is of great importance in the differentiation of pollen types. The pollen grains are either more or less spheroidal or they are suboblate to oblate. To the former group of pollen types belong all Tapura types, one Dichapetalum type (Dichapetalum bangii type) and the Stephanopodium engleri type. All other Dichapetalum types are suboblate to oblate.

\section{Apertures}

Ectoaperture: The ectoaperture shows a large number of variations. It is always a colpus which can be long (in all nearly spheroidal pollen types) or short to very short in most of the suboblate to oblate pollen types. None of the pollen types shows an ectoporus, but in a few types the ectoaperture is absent. The colpi are usually narrow, often very narrow (slit-like) and they are typically not sunken although slightly sunken in the Dichapetalum gelonioides type. The colpus margins are distinct in most of the types, but 
in a few (Dichapetalum angolense type) they are irregular and indistinct. The colpus ends are nearly always acute, with the exception of the Dichapetalum gelonioides type and $D$. grandifolium type. Costae colpi are present in a few types (Dichapetalum barbosae type), but this feature is of minor importance in the Dichapetalaceae. A margo is present only in one group of the Dichapetalum gilletii type. Far more important is the presence of a fastigium in the group of spheroidal pollen types (Dichapetalum bangii type, Tapura amazonica type). In most types the fastigia are small, but distinct.

Endoaperture: These vary from lalongate colpi to circular or rectangular pori; in the Dichapetalum barbosae type the endoporus is slightly lolongate. The size varies from small to large. The variation of the endoaperture seems less important in oblate pollen types than in more or less spheroidal pollen types. Indeed, the differentiation of the latter is mainly based on the size and outline of the endoaperture. The margins of the endoaperture are usually indistinct, but sometimes distinct. A few pollen types show grains with costae along the endoapertures (Tapura bouqetiana type, Dichapetalum gelonioides type), but this feature occurs only sporadically and is of minor importance.

Two types, the $D$. gelonioides type and the $D$. pedunculatum type, show pollen grains with slightly protruding apertures.

\section{Exine}

The exine is usually thin and does not show much variation in thickness, but two types, the Dichapetalum macrocarpum type and Tapura bouquetiana type, have an exine markedly thicker than in any other. In most pollen types the sexine is about as thick as the nexine, but in the two types with a rather thick exine the sexine is distinctly thicker than the nexine. In some other Dichapetalum types the sexine can be distinctly thinner than the nexine ( $D$. barteri type).

The sexine consists of two layers: sexine 1 and sexine 2 . In most pollen types the sexine 1 is about as thick as the sexine 2 . The sexine 1 is a layer of short, thin columellae, often indistinct. The sexine 2 is a semi-tectate layer or, less often, a pertectate layer, both without supratectal processes. In optical section the sexine 2 often shows small, nearly circular capita. In a few types the capita are elongated sidewards (Dichapetalum chlorinum type) and in some other types where the sexine is reduced the capita are indistinct (Dichapetalum madagascariense type).

\section{Ornamentation}

The ornamentation of the pollen grains is very variable. Most pollen types are reticulate or microreticulate, but a few are pertectate. If, however, the pollen grains are tectate, the tectum is extensively perforate.

The muri in the reticulate and microreticulate pollen grains are thin, they 
often lack a distinct differentiation into a columellate part and a tectal part. In some types (Dichapetalum thollonii type) the muri are thin at the top and broader towards the base while other types have muri which are distinctly interrupted at the apocolpium (Dichapetalum heudelotii type).

The lumina of the reticulum are irregular in shape. They often decrease in size towards the ectoapertures and sometimes also towards the mesocolpia in the equatorial plane. A couple of pollen types show an ornamentation of elongated sexine elements, here called pila, arranged irregularly all over the grains (Dichapetalum gilletii type). One other type (Dichapetalum barbosae type) has a pilate ornamentation in the mesocolpium only.

In some pollen types the sexine is so reduced that the ornamentation is faint or indistinct (Dichapetalum barteri type).

In the Dichapetalum gelonioides type one group (Sumatranum group) shows irregular, narrow grooves in the sexine 2, which grooves usually form a coarse reticulum with large pieces of tectum of irregular shape and size in between (Plate VI, 6, 7).

\section{Outlines}

Polar view: In most pollen types the outline is triangular in polar view; rarely the outline is circular (Tapura coriacea type), the sides vary from distinctly convex (Dichapetalum bangii type) to concave (Dichapetalum barbosae type); the angles vary from distinctly obtuse to nearly acute (subacute). The apertures are always situated at the angles.

Equatorial view: The outline in equatorial view is usually elliptic, rarely circular or rectangular (Tapura bouqetiana type). In some oblate pollen grains the long sides are concave. This latter feature is caused by the sunken position of the apocolpium (sunken poles). If, in suboblate or oblate pollen grains, two mesocolpia are seen in optical section, then the short sides are obtuse and the outline is elliptic. However, if one colpus is seen in optical section and the mesocolpium is at the other side, the outline is pear-shaped and the colpus part is more or less acute.

\section{Measurements}

The overall size of the pollen grains is usually small; the largest type (Dichapetalum macrocarpum type) having a longest axis of up to $35 \mu$. In most pollen types, however, the largest ax is does not exceed $20 \mu$.

The lumina of the reticula are usually ca. $1 \mu$ wide or only slightly more. The width is never more than $2 \mu$.

The exine is usually ca. $1 \mu$ thick, sometimes slightly thicker; rarely up to $2 \mu$ thick. 
KEY TO THE DICHAPETALACEAE POLLEN TYPES $(D .=$ Dichapetalum; $S .=$ Stephanopodium; $T .=$ Tapura)

1.a. Grains oblate, suboblate to distinctly oblate-spheroidal or grains inaperturate; i.e. one axis distinctly longer . . . . . . . . . . . 2

b. Grains \pm spheroidal (slightly prolate-spheroidal to slightly oblatespheroidal) or prolate-spheroidal; fastigiate. . . . . . . . . . 43

2.a. Grains covered with pila or verrucate; nowhere reticulate; sexine

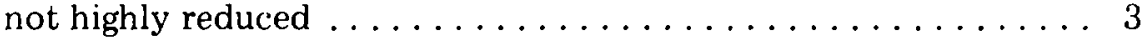

b. Pollen grains tectate, at least partially reticulate or sexine highly reduced ........................ 4

3.a. Pila indistinct, small, crowded, mainly visible as LO pattern; circular in optical section; sexine thinner than nexine $\ldots \ldots D$. mundense type

b. Pila distinct, irregularly arranged; usually irregular shaped in optical section; sexine \pm as thick as nexine; pollen grains sometimes verrucate $\ldots \ldots \ldots \ldots \ldots$. gilletii type

4.a. Sexine highly reduced, very faintly visible and sometimes completely lacking, al ways distinctly thinner than nexine ...... D. barteri type

b. Sexine may be reduced at apocolpium, but always present in

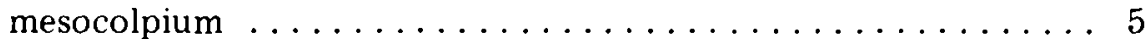

5.a. Grains with interrupted muri either at apocolpium or in mesocolpium; this may be only slightly present ............66

b. Grains without interrupted muri in any part or pollen grains tectate. . . . . . . . . . . . . . . . . . . . . . 19

6.a. Sides of grain distinctly concave in polar view; finely pilate in the mesocolpia (interrupted muri)........... D. barbosae type

b. Sides of grain straight or convex in polar view. . . . . . . . . 7

7.a. Lumina of reticulum not or only slightly decreasing towards the apertures; ectoapertures short, indistinct or absent ......... 8

b. Lumina of the reticulum distinctly decreasing towards the

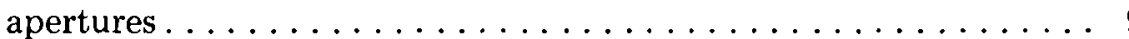

8.a. Reticulum fine; in equatorial view long sides slightly concave; i.e. with sunken poles; in polar view, sides straight or slightly convex. .................... angolense type

b. Reticulum coarse; in equatorial view long sides distinctly convex; in polar view sides slightly to distinctly convex. . . D. zenkeri type

9.a. Pollen grains inaperturate . . . . . . . . . . . . . 10

b. Pollen grains colporate; colpi may be very short or indistinct . . . . 12

10.a. Sexine usually distinctly, sometimes only slightly thinner than nexine; muri often thin above, thicker below. .D. madagascarense type

b. Sexine about as thick or thicker than nexine, rarely slightly thinner than nexine; muri usually as thick above as below. . . . . . . . . 11

11.a. Sides of grain slightly to distinct convex in polar view; angles distinctly obtuse .................. leucosia type

b. Sides of grain slightly to distinct convex in polar view; angles usually subacute, sometimes obtuse (inaperturate forms of

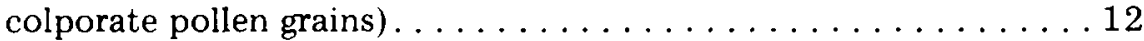


12.a. In polar view angles distinctly obtuse; sides straight to slightly concave; poles not sunken; muri slightly thicker below .....D. choristilum type

b. In polar view angles subacute, or if obtuse angles then sides slightly convex...................... 13

13.a. Sexine distinctly thinner than nexine, sometimes only slightly thinner; muri usually thin above and thicker below; capita never spherical in optical section; colpi often slightly broader in the equatorial plane. . . . . . . . . . . . D. madagascariense type

b. Sexine about as thick as nexine, sometimes slightly thinner, but then muri not distinctly thicker below, or if slightly thicker then sexine certainly not thinner than nexine . . . . . . . . . . 14

14.a. Reticulum at apocolpium distinctly with interruptions; in this area the ornamentation is pilate; in equatorial view the long sides distinctly concave (sunken poles); in the mesocolpia the meshes of the reticulum are very small and sometimes the sexine 2 is a complete tectum ................. D. mombuttense type

b. Reticulum at apocolpium slightly or distinctly interrupted, but without pilate ornamentation and mesocolpia never tectate . . . 15

15.a. In polar view angles obtuse and sides slightly convex; muri distinctly thicker below; colpi slightly broadened in the equatorial plane; endoapertures rather large. . . . . . . . . D. thollonii type

b. In polar view angles subacute and sides slightly to distinctly convex; muri thin from top to base or only slightly thicker

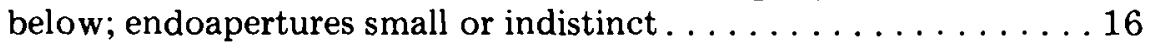

16.a. Reticulum very coarse; muri slightly thicker below ................... longipetalum type

b. Reticulum fine or coarse; muri thin from top to base . . . . . . 17

17.a. Colpi long or rather long; very narrow; reticulum coarse at the poles and often the muri are not distinctly interrupted .................. D. crassifolium type

b. Colpi short and only rarely rather long; if rather long then muri distinctly interrupted or reticulum not coarse at poles . . . . 18

18.a. Poles not sunken; sides usually distinctly convex . . . D. zenkeri type

b. Poles sunken; sides usually straight or only slightly convex...................... heudelotii type

19.a. Sides of grains concave in polar view (at least one side concave), not including the protruding angles; angles obtuse $\ldots \ldots \ldots \ldots 20$

b. Sides of grains straight or convex in polar view . . . . . . . . 21

20.a. Reticulum coarse or rather coarse at apocolpium and slightly decreasing towards colpi; colpi with distinct margins . . . . . . . . . . . . . . D. choristilum type

b. Reticulum fine all over grain; colpi indistinct ... D. angolense ty pe

21.a. Pollen grains tectate ..................... 22

b. Pollen grains distinctly reticulate, i.e. lumina as wide as muri or

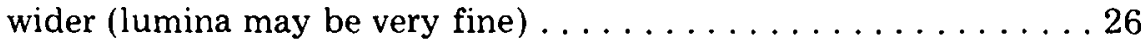

22.a. Pollen grains pertectate; sexine 2 without perforations or with a 
few indistinct perforations; grains relatively

large. . . . . . . . . . . . . . . D . grandifolium type

b. Tectum with numerous perforations; grains small or large. . . . . 23

23.a. Grains inaperturate; angles distinctly obtuse.... D. timoriense type

b. Grains distinctly colporate; angles obtuse or subacute. . . . . . 24

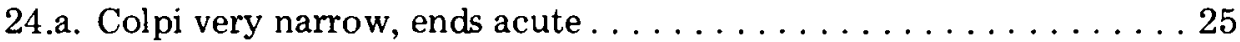

b. Colpi not very narrow, ends rounded. ..... D. gelonioides type p.p.

25.a. Apertures distinctly protruding in equatorial plane; in equatorial view poles usually sunken; endoaperture circular to only slightly lalongate . . . . . . . . . . . . . . . Dedunculatum type

b. Apertures not or indistinctly protruding; in equatorial view poles not sunken; endoaperture distinctly

lalongate . . . . . . . . . . . . . .

26.a. Grains inaperturate . ..................... 27

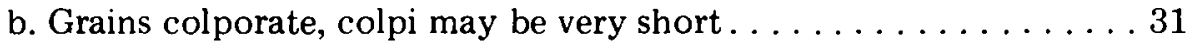

27.a. Reticulum usually coarse, rarely rather coarse; in equatorial view poles not sunken . . . . . . . . . . . . . . D. zenkeri type

b. Reticulum fine, if reticulum rather coarse at apocolpium, then poles sunken in equatorial view. . . . . . . . . . . . 28

28.a. Grains with subacute angles in polar view ....... D. heudelotii type

b. Grains with distinctly obtuse angles. . . . . . . . . . . . 29

29.a. Reticulum decreasing towards angles; poles not sunken....................... D. leucosia type

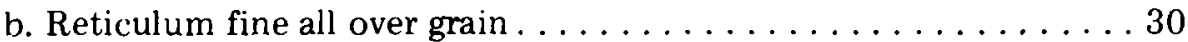

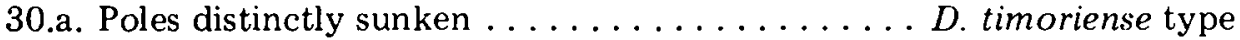

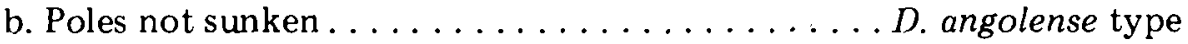

31.a. Reticulum coarse to rather coarse $\ldots \ldots \ldots \ldots \ldots \ldots \ldots \ldots 2$

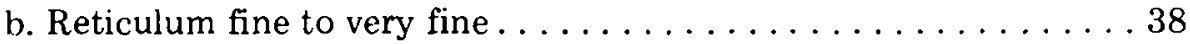

32.a. Grains large ( $\mathrm{E}$ larger than $25 \mu$ ); sexine distinctly thicker than nexine; in polar view sides straight to slightly convex and angles distinctly obtuse; in equatorial view long sides convex. ................... D. macrocarpum type

b. Grains smaller (E less than $25 \mu$ ); sexine usually not thicker than nexine ................................. 33

33.a. Grains with long, almost syncolpate colpi, narrow, with distinct margins; lumina distinctly decreasing towards the colpi; since colpi are long, lumina at apocolpium smaller than in equatorial plane ...................... chlorinum type

b. Pollen grains with shorter colpi; lumina not smaller at apocolpium than in mesocolpium....................... 34

34.a. Muri thin above and distinctly thicker below; in polar view sides slightly convex .................. thollonii type

b. Muri thin above and below, or if base slightly thicker, then with

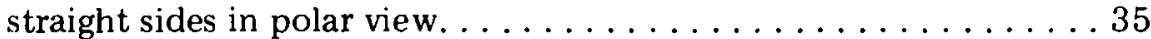

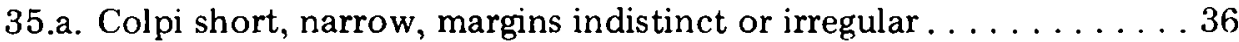

b. Colpi usually long or rather long, sometimes short, but al ways 
with margins distinct, straight . . . . . . . . . . . . 37

36.a. Exine relatively thick; sexine slightly thicker than nexine; colpi with rather diffuse, irregular margins......... D. papuanum type

b. Exine relatively thin; sexine slightly thinner than nexine; colpi indistinct....................... D. zenkeri type

37.a. In polar view pollen grains subacute with nearly straight to slightly convex sides; lumina of the reticulum distinctly decreasing towards the colpi; muri not thicker towards the base; endoapertures small and indistinct ........ D. crassifolium type

b. In polar view pollen grains distinctly obtuse with straight to slightly concave sides; lumina of the reticulum not or only slightly decreasing towards the colpi; muri slightly thicker below; endoapertures large ............. D. choristilum type

38.a. Exine relatively thick; columellae short, but distinct; in polar view sides distinctly convex; colpi with rather diffuse, irregular margins .................... D. papuanum type

b. Exine thin; columellae usually indistinct; colpi distinct or indistinct, but usually with regular margins .

39.a. Apertures protruding in the equatorial plane; colpi very narrow; in equatorial view grains usually with sunken poles

D. pedunculatum type

b. Apertures not protruding; poles rarely sunken (sunken

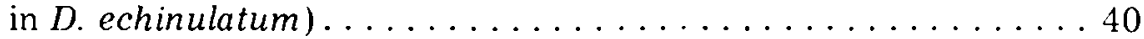

40.a. Colpi with distinct margins, short, rather long or long. . . . . . . 41

b. Colpi with indistinct margins, short. ........ D. angolense type

41.a. Colpi with rounded ends or if not rounded, with distinct lalongate endoaperture; lumina usually narrower than muri. . . . . . . . . . . . . . . . . . D. gelonioides type

b. Colpi very narrow, with acute ends; endoaperture indistinct; lumina as wide as, or slightly wider than muri. . . . . . . . 42

42.a. Lumina not decreasing towards colpi ....... D. parvifolium type

b. Lumina distinctly decreasing towards colpi ........... D. crassifolium type p.p. (D. echinulatum)

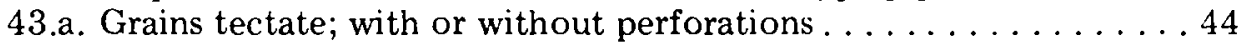

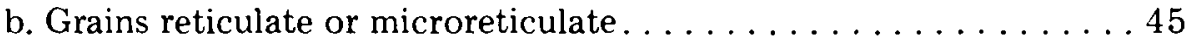

44.a. Endoapertures large, rectangular in outline, bordered by faint costae; in polar view distinctly triangular with straight to slightly concave sides and distinctly obtuse angles......T. bouquetiana type

b. Endoapertures large, broadly elongated pori or colpi, without costae; in polar view slightly triangular to nearly circular; sides distinctly convex................... engleri type

45.a. Reticulum coarse or rather coarse; endoapertures distinct rectangular pori or broad colpi with faint costae and diffuse ends......................... T. ivorense type

b. Reticulum fine or very fine (microreticulate); rarely coarse in mesocolpium, but then endoaperture indistinct; endoapertures 
varying in outline $\ldots \ldots \ldots \ldots \ldots \ldots \ldots \ldots \ldots \ldots$

46.a. Endoapertures distinct, colpi with faint costae; in equatorial view more or less quadrangular with convex sides .... T. juliani type

b. Endoapertures varying in outline, but always without costae; in

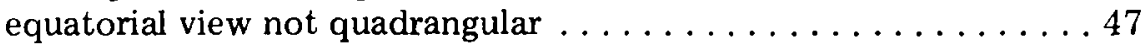

47.a. Pollen grains in polar view nearly circular or slightly triangular; endoapertures very narrow; indistinct endocolpi... . T. coriacea type

b. Pollen grains in polar view distinctly triangular; sides slightly or distinctly convex; endoapertures narrow or broad . . . . . . 48

48.a. Endoapertures small, narrow and usually with diffuse margins . . . . . . . . . . . . . . . . . D. bangii type

b. Endoapertures rather broad, not small and usually diffuse only at outer ends .................... T. amazonica type

\section{DESCRIPTION OF THE POLLEN TYPES}

\section{Dichapetalum angolense type (Plates I, II)}

Pollen class: Colporate or inaperturate; ectoapertures often indistinct. Number of apertures (ecto- and endoapertures) usually 3 , rarely 4 . In some specimens the number of 4-colporate pollen grains can be rather high. $P / E$ ratio: Mostly oblate, rarely suboblate.

Apertures: Ectoapertures - absent or present; if present a short, narrow or broad colpus; ends acute; margins distinct. Endoapertures - indistinct and if present usually a circular porus, of ten rather large; no costae.

Exine: Relatively thin. Sexine about as thick as nexine, sometimes slightly thinner, or thicker than nexine. Columellae indistinct and low, rarely distinct ( $D$. bocageanum). Capita small, nearly circular in outline.

Ornamentation: Reticulate or microreticulate. Reticulum usually continuous, but in a few species the muri at the poles interrupted (Angolense group). Lumina al ways small and irregular in shape, neither decreasing towards the apertures nor the equatorial plane. Muri thin in most species, but in some slightly thicker below ( $D$. librevillense, $D$. dewevrei).

Outlines: Polar view - triangular; sides straight to slightly convex; angles often distinctly obtuse, sometimes more or less subacute. Equatorial view - elliptic with obtuse ends in the equatorial plane; long sides usually convex, sometimes slightly concave (sunken at poles), e.g. $D$. angolense and $D$. bocageanum.

Measurements: $\mathrm{P} 7-17 \mu ; \mathrm{E} 10-23 \mu ; \mathrm{P} / \mathrm{E}$ ratio $(0.54-) 0.60-0.70(-0.78)$. Lumina of reticulum usually smaller than $1 \mu$, but regularly up to ca. $1 \mu$. Exine ca. $1 \mu$ or thinner.

Key to the pollen groups and species

1.a. Angles in polar view distinctly obtuse; endoapertures large, muri

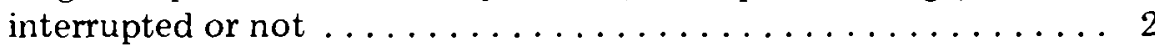

b. Angles in polar view subacute; endoapertures small; muri not 
interrupted......................... 3

2.a. Poles sunken; muri often interrupted; microreticulate; grains rather small $(12-18 \mu) \ldots \ldots \ldots \ldots \ldots \ldots \ldots$ Angolense group

b. Poles usually not sunken; muri not interrupted; microreticulate to reticulate; grains rather large $(15-23 \mu) \ldots \ldots \ldots$ Pallidum group

3.a. Reticulate; poles not sunken; grains rather large $(13-17 \mu) \ldots \ldots \ldots \ldots \ldots \ldots \ldots \ldots \ldots \ldots \ldots$ D. cinereum

b. Microreticulate; poles sunken to not sunken; grains small $(12-14 \mu) \ldots \ldots \ldots \ldots \ldots \ldots \ldots \ldots \ldots \ldots$ Ugandense group

Species: Angolense group: D. angolense, D. bocageanum, D. zenkeri (p.p., Mildbread 3913)

D. cinereum

Pallidum group: $D$. albidum, $D$. barbatum, $D$. brazzae (p.p.), $D$. deflexum, $D$. dewevrei (p.p.), D. liberiae, D. librevillense, D. lofaense, D. mossambicense, D. pallidum

Ugandense group: D. costatum, D. brazzae (p.p., Bates 1194), D. deweurei (p.p., Zenker 3741), D. ugandense

\section{Comment}

The $D$. angolense type is rather heterogeneous. There are only few constant features; most of the characteristics are rather variable. The short to very short, often indistinct ectocolpi with indistinct, irregular margins together with the small lumina of the reticulate or microreticulate ornamentation which never decrease towards the apertures, or equatorial plane are the most characteristic features of the $D$. angolense type. The Pallidum group is the most variable of the type.

Angolense group (Plate II, 1-5, 7, 8, 17; Plate XIX, 2). This group shows the largest variation in the basic features of the pollen type. The muri of the reticulum are often slightly interrupted and the poles are slightly sunken. Because of these two features the pollen grains show a close resemblance to the $D$. heudelotii type, but the small, indistinct colpi with irregular margins and the reticulum with constant lumina size place this group firmly in the $D$. angolense type.

Apart from $D$. angolense, $D$. bacogeanum is placed in this group. The main difference between the two species is in the muri. In the latter species the muri are not interrupted, whereas in the former species the muri are slightly interrupted. But the similarity between the two species is their distinctly sunken poles, their outlines in polar view, and their large endoapertures place them in one group. As in the Ugandense group, the grains have a thin exine and a rather faint reticulum (sexine thinner than nexine).

$D$. cinereum. This species undoubtedly belongs to the $D$. angolense type because of its constant reticulum size and its small, indistinct colpi. It differs from the other groups in having a distinct reticulum (lumina ca. $1 \mu$ ), 
slightly but distinctly convex sides and small, indistinct endoapertures. The group is intermediate between the Pallidum group (also with a distinct reticulum and elliptic equatorial view) and the Ugandense group with its small, indistinct endoapertures and subacute angles in polar view.

Pallidum group (Plate I, 5-18; Plate 1I, 10-14, 18-20). In this large group the grains resemble each other to some extent, but it is possible to differentiate most species by special features. The differences are usually restricted to one or two characteristics and these are often intermediates. Constant features are: (1) outline in polar view; (2) outline in equatorial view; (3) muri of the reticulum not interrupted; (4) endoapertures usually indistinct and large. The most important variations are found in the colpus, the thickness of the muri and the width of the lumina.

$D$. albidum and $D$. deflexum: Both species resemble each other so closely that they cannot be differentiated from one another. They are the smallest pollen grains in the group ( $\mathrm{E}$ ca. $15 \mu$ ) and lack ectoapertures as does the pollen of $D$. mossambicense. The outline of the grains is remarkably similar to that in $D$. liberiae.

D. brazzae: Grains of this species differ from those of all other species in the Pallidum group by their larger size (E is ca. $22 \mu$ ) and in the polar view outline where the sides are distinctly convex. Another striking feature is that the muri are thin at the top and slightly thicker below, a feature also present in $D$. librevillense, $D$. dewevre $i$ and in the $D$. madagascariense type. In their short, broad ectoaperture the pollen grains show an affinity with those of $D$. pallidum.

D. dewevrei: The specimens of this taxonomically complicated species show pollen grains which may be separated into three groups. The largest group is placed in the Pallidum group, one specimen is placed in the Ugandense group and another in the $D$. heudelotii type. The specimens Breteler 6602 and Dacremont 213 are those specimens in this variable species which show best the most typical characteristics: indistinct, short colpi with irregular margins; the small lumina do not decrease towards the apertures; apocolpium slightly sunken; muri slightly thicker below; sexine slightly thinner than nexine. The slightly sunken poles point to a morphological relationship with the species of the Angolense group and the Ugandense group. The thickened muri, on the other hand, are a special feature of $D$. brazzae and $D$. librevillense and this feature is also important in other pollen types such as the $D$. madagascariense type and the $D$. thollonii type. The specimen Zenker 3741 undoubtedly belongs to the Ugandense group but it has a higher proportion of 4-colporate grains than is usual, and one 5-colporate has been observed. The specimen Klaine 3353 shows a close resemblance to specimens of the $D$. heudelotii type: its reticulum is rather coarse at the poles and the lumina decrease distinctly towards the apertures; its colpi are short to rather long with distinct margins; its outline in polar view is subacute and its endoapertures are small and indistinct. It differs however in the muri which are slightly 
thicker below. Although Klaine 210 belongs to the $D$. angolense type, it differs from the other specimens in many features. The main difference is the absence of ectoapertures; but in addition, the muri are not thicker below while the lumina are rather coarse and very irregular. On the other hand, the lumina of the reticulum do not decrease towards the colpi and the sexine is slightly thinner than the nexine.

$D$. liberiae: The pollen grains of this species resemble those of $D$. pallidum very closely. There is a tendency to slightly convex sides, but this difference is rather vague. The remarkable short, but rather broad ectocolpus is a feature also present in pollen grains of $D$. pallidum and $D$. brazzae.

$D$. librevillense: The pollen grains of this species resemble those of $D$. brazzae very closely, but they differ in size. The equatorial diameter is ca. $15 \mu$, whereas that of $D$. brazzae is ca. $22 \mu$. All other features are similar.

$D$. lofaense: The pollen grains of this species probably belong to the Pallidum group. The reticulum is continuous; the colpi are short with indistinct margins; the size is rather large and the angles in polar view obtuse. Unfortunately it was not possible to examine enough grains of sufficient quality to allow accurate conclusions to be formed about the position of this species.

D. mossambicense: A species with pollen grains resembling those of D. pallidum very closely. The grains are, however, inaperturate and the outline in polar view has angles which are more distinctly obtuse than those of $D$. pallidum or of $D$. liberiae.

D. pallidum (Plate XIX, 1, 2): The most important characteristics of this species are: pollen grains in polar view with almost straight sides; colpi short and broad; sexine about as thick as nexine; reticulum distinct; muri thin, not thicker below.

Ugandense group (Plate II, 6, 9, 15, 16). The pollen grains in the Ugandense group are related both to the Pallidum group and the Angolense group. They are small and they often have sunken poles in equatorial view. The muri, however, are never interrupted. The grains also resemble those of $D$. cinereum in their outline in polar view and their small, indistinct endoapertures. It is also striking that the sexine is usually thinner than the nexine thus making the ornamentation rather faint.

\section{Dichapetalum bangii type (Plate III, 1-8; Plate XIX, 4)}

Pollen class: 3-Colporate, rarely 4-colporate.

$P / E$ ratio: Usually spheroidal; sometimes slightly prolate-spheroidal or slightly oblate-spheroidal.

Apertures: Ectoapertures - colpi, long, narrow, and slightly sunken; margins straight and distinct; no costae; fastigium small, but distinct, not much protruding. Endoapertures - usually indistinct, lalongate colpi, narrow and small; margins diffuse and indistinct; no costae. Exine: Thin sexine about as thick as nexine or slightly thicker. Columellae 
short and indistinct; capita small and circular in optical section; capita layer about as thick as columellae layer or slightly thicker.

Ornamentation: Finely reticulate or microreticulate. Muri thin, never interrupted, usually simplicolumellate, sometimes duplicolumellate. Lumina irregular in shape, as wide as muri or slightly wider; sometimes slightly decreasing towards the poles.

Outlines: Polar view - triangular; sides slightly to distinctly convex; angles obtuse to slightly subacute. Equatorial view - circular or slightly elliptic; sides distinctly convex.

Measurements: $\mathrm{P} 10.5-19 \mu ; \mathrm{E} 10.5-20 \mu ; \mathrm{P} / \mathrm{E}$ ratio $0.84-1.13$, usually in a range between 0.95 and 1.05 . Exine ca. $1 \mu$ thick. Lumina varying from less than $0.5 \mu$ to ca. $1.5 \mu$.

Species: $D$. arachnoideum, $D$. bangii, D. gillardinii, $D$. fructuosum, D. lujaei, $D$. nyangense, $D$. rhodesicum

\section{Comment}

The $D$. bangii type differs in many characteristics from the other Dichapetalum types. The pollen grains are more or less spheroidal whereas those of all other Dichapetalum types are more or less oblate to oblate. Apart from this important characteristic the endoaperture is a slightly sunken colpus. Because of these features the type can be sharply differentiated.

On the other hand, the type shows many characteristics in common with the Tapura types. The main difference is the indistinct, usually small and narrow endocolpus with diffuse margins. It is also most striking that the pollen of the Dichapetalum bangii type has a great deal in common with that of the American representatives of the Tapura amazonica type. The African representatives show pollen grains which are slightly better to differentiate because of the less convex sides in polar view.

The Dichapetalum bangii type is homogeneous and all pollen grains are very much alike. Pollen of $D$. fructuosum differs only in having slightly larger grains.

\section{Dichapetalum barbosae type (Plate III, 9-18; Plate XX, 1)}

Pollen class: 3-Colporate.

$P / E$ ratio: Suboblate to oblate.

Apertures: Ectoapertures - colpi, short to long, very narrow, not sunken; distinct margins; costae present or absent. Endoapertures - lolongate colpi or lolongate, elliptic pori; ends obtuse; margins rather indistinct.

Exine: Relatively thin. Sexine distinctly thinner in the apocolpium; in the mesocolpium the sexine elements are about as thick as nexine. Columellae short and indistinct; capita small, almost circular in outline.

Ornamentation: In polar view the pollen grains show a faint, very fine (microreticulate) ornamentation; muri, if faintly visible, sometimes interrupted; lumina wider towards the equatorial plane. In equatorial view 
the mesocolpia show small, scattered elements (pila).

Outlines: Polar view - triangular; sides distinctly concave; angles obtuse to truncate. Equatorial view - elliptic; long side convex, not sunken at the poles; short sides slightly truncate.

Measurements: $\mathrm{P} 9-13 \mu ; \mathrm{E} 15-18 \mu ; \mathrm{P} / \mathrm{E}$ ratio $0.58-0.78$. Exine ca. $1 \mu$ thick. Lumina at the poles smaller than $1 \mu$.

Species: D. arenarium, $D$. barbosae

Key to the species

1.a. Colpi with costae $\ldots \ldots \ldots \ldots \ldots \ldots \ldots \ldots$ arenarium

b. Colpi without costae $\ldots \ldots \ldots \ldots \ldots \ldots \ldots \ldots$ D. barbosae

\section{Comment}

Both species of the $D$. barbosae type are very similar. They have the following striking features in common: (1) sides in polar view distinctly concave; (2) the mesocolpial part of the equatorial plane has scattered pila. This last feature in particular is unique in the Dichapetalaceae.

It is difficult to determine which of the other types in the Dichapetalaceae have the closest morphological affinities with the $D$. barbosae type. The sexine is distinctly thinner than the nexine, a relationship with the $D$. madagascariense type is indicated, but the outline in polar view is much more like some species in the $D$. angolense type (e.g. D. mossambicense) and the $D$. choristilum type. It may be best to place the $D$. barbosae type between the $D$. choristilum type and $D$. madagascariense type in the vicinity of the $D$. angolense type.

\section{Dichapetalum barteri type (Plate IV, 1-9)}

Pollen class: 3-Colporate, rarely 4-colporate.

$P / E$ ratio: Oblate.

Apertures: Ectoapertures - colpi varying from short to long, very narrow, but often slightly broadened in the equatorial plane, sometimes slightly sunken; ends acute; margins distinct. Endoapertures - pori, circular or lalongate, small and usually indistinct.

Exine: Thin. Sexine always highly reduced and distinctly thinner than nexine. Nexine often irregularly incised on the inner face. Sexine elements cannot be differentiated into columellae and capita.

Ornamentation: Sexine elements so reduced that no ornamentation can be distinguished in polar view. Sometimes a faint reticulum is present around the mesocolpium; other specimens show irregular patterns.

Outlines: Polar view - triangular; sides slightly to distinctly convex; angles usually subacute. Equatorial view - elliptic; long sides convex or concave (with or without sunken poles); outline acute, if the colpus is seen in optical section.

Measurements: P 7-21 $;$ E $11-21 \mu ; \mathrm{P} / \mathrm{E}$ ratio $0.56-0.75$. Exine usually thinner than $1 \mu$. 
Species: D. barteri, D. braunii, D. cazengoense, D. integripetalum, D. luki, $D$. ruhlandii, D. stuhlmannii

Key to the pollen groups

1.a. Colpi short or absent; sides in polar view distinctly convex ...................... Ruhlandii group

b. Colpi rather long or long; sides in polar view usually slightly convex ......................... Barteri group*

\section{Comment}

The $D$. barteri type is easily recognized by its indistinct sexine ornamentation. The sexine is highly reduced and may be absent. In this feature the type shows the final step in the sequential reduction of the sexine. The pollen grains of the $D$. barteri type resemble those of the $D$. madagascariense type very closely as the latter type also have pollen grains where the sexine is thinner than the nexine. Both types resemble each other very closely in other features such as the outline in polar and equatorial view and the distinct, narrow colpi, which are sometimes slightly widened at the equator.

The Ruhlandii group shows pollen grains which are so different in outline and colpus features that the pollen grains might be placed in a separate pollen type. But the faint, highly reduced sexine is such a striking feature, not present in any other Dichapetalum type, that it seems best to keep the pollen grains in the $D$. barteri type.

\section{Dichapetalum chlorinum type (Plate IV, 10-17)}

Pollen class: 3-Colporate.

$P / E$ ratio: Oblate.

Apertures: Ectoapertures - long, very narrow, slit-like, nearly syncolpate; ends acute; margins distinct; no costae. Endoapertures - circular pori, small and indistinct; no costae.

Exine: Relatively thick. Sexine thicker than nexine. Columellae short and indistinct; capita thick, elongated sideways.

Ornamentation: Pollen grains reticulate. Reticulum coarse. Muri rather thin at the top, thicker towards the base, simplicolumellate to duplicolumellate; not interrupted. Lumina irregular in shape, distinctly decreasing towards the colpi. Because of the length of the colpi the lumina are smaller at the apocolpium than in the equatorial plane.

Outlines: Polar view - triangular; sides slightly convex; angles obtuse. Equatorial view - elliptic; long sides with sunken poles; short sides obtuse in the mesocolpium and acute if the colpus is seen in optical section. Measurements: $\mathrm{P} 10-13 \mu ; \mathrm{E} 16.5-20 \mu ; \mathrm{P} / \mathrm{E}$ ratio $0.57-0.69$. Exine up to $1.5 \mu$. Lumina up to $2 \mu$. In the equatorial plane and less than $1 \mu$ along the colpi and at the apocolpium.

\footnotetext{
*The Barteri group comprises all species, except $D$. ruhlandii and $D$. cazengoense.
} 
Species: D. chlorinum

\section{Comment}

The $D$. chlorinum type is difficult to place among the other types. It has some striking features such as: (1) coarse reticulum with often duplicolumellate muri; (2) long, nearly syncolpate colpi; (3) lumina distinctly decreasing towards the colpi, and because of the long colpi the lumina in the apocolpium are smaller in width than in the equatorial plane. This latter feature is most unusual in the Dichapetalaceae. The continuity of the reticulum suggests a close relationship with the $D$. angolense type but this is contradicted by the coarse reticulum and the sunken poles. On the other hand, the thickening of the muri towards the base is present in some species of the $D$. angolense type. The $D$. chlorinum type has also some features in common with the $D$. thollonii type (p. 38) and it seems best to keep both types close together near that part of the $D$. angolense type which comprises species with similar muri $(D$. deweurei, $D$. librevillense).

\section{Dichapetalum choristilum type (Plate V, 1-8)}

Pollen class: 3-Colporate.

$P / E$ ratio: Oblate.

Apertures: Ectoapertures - colpi varying from short to rather long, narrow, slightly broadened in the equatorial plane; ends acute; margins distinct; no costae. Endoapertures - large circular pori; margins indistinct; no costae. Exine: Thin. Sexine varying from about as thick as nexine to slightly thinner or thicker than nexine. Columellae short and indistinct; capita nearly circular in outline.

Ornamentation: Coarse reticulum. Muri thin above and thicker below; not or only slightly interrupted. Lumina irregular, elongated or broadly angular; not markedly decreasing towards the equatorial plane, but slightly decreasing towards colpus margins, especially at the angles.

Outlines: Polar view - triangular; sides straight to slightly concave or rarely slightly convex; angles obtuse. Equatorial view - elliptic if both mesocolpia are seen in optical section. However, if one colpus is seen in optical section the outline is pear-shaped; long sides slightly concave, straight or slightly convex; poles sometimes sunken.

Measurements: P $10-15 \mu ; \mathrm{E} 16-22 \mu ; \mathrm{P} / \mathrm{E}$ ratio $0.56-0.74$. Exine ca. $1 \mu$ thick. Lumina up to $3 \mu$ wide.

Species: D. choristilum, D. edule

Key to the species

1.a. Poles distinctly sunken; sexine slightly thicker than

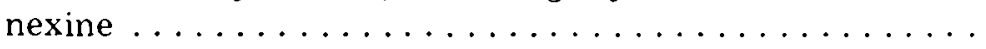

D. edule

2.a. Poles not sunken; sexine as thick as, or slightly thinner than nexine ......................

D. choristilum 


\section{Comment}

$D$. choristilum and $D$. edule look rather similar but they differ in a few features. In $D$. edule the muri are less thickened towards the base and the overall size is slightly larger. The grains show a striking affinity to the $D$. macrocarpum type, but this latter type differs by a greater overall size, smaller colpi and sexine distinctly thicker than nexine.

The $D$. choristilum type resembles the $D$. angolense type in many features, in particular some species in the $D$. pallidum group ( $D$. dewevrei, $D$. librevillense, etc.). The most important difference is found in the colpi which are short and often indistinct in the $D$. angolense type but rather long with distinct margins in the $D$. choristilum type. Moreover, the lumina in $D$. choristilum decrease slightly towards the colpi. On the other hand, the type also shows some relationship with the $D$. heudelotii type, but this differs in both polar and equatorial outline.

\section{Dichapetalum crassifolium type (Plate V, 9-12)}

Pollen class: 3-Colporate, rarely 4-colporate.

$P / E$ ratio: Oblate.

Apertures: Ectoapertures - colpi, rather long to long, very narrow, slit-like, ends acute, margins distinct; no costae. Endoapertures - pori, usually indistinct, circular to lolongate, usually small; no costae.

Exine: Exine thin. Sexine about as thick as nexine or slightly thicker. Columellae short and indistinct. Capita small, circular in outline or slightly elongated sideways.

Ornamentation: Reticulum, coarse at poles and fine (microreticulate) towards colpi and equatorial plane. Muri thin, not thicker towards the base; often slightly interrupted. Lumina irregular in shape, distinctly decreasing towards colpi and equatorial plane.

Outlines: Polar view - triangular; sides distinctly convex to nearly straight; angles subacute. Equatorial view - elliptic; long sides parallel or slightly concave (sunken poles); short sides obtuse if mesocolpium in optical section and slightly acute if colpus is seen in optical section.

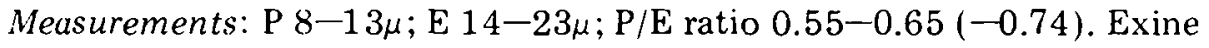
ca. $I \mu$ thick. Lumina up to $3 \mu$ at the poles, often less than $1 \mu$ in the equatorial plane.

Species: D. crassifolium, D. echinulatum

\section{Comment}

The $D$. crassifolium type and the $D$. heudelotii type resemble each other very closely. The outline in polar view, the subacute angles, the sunken poles, the indistinct apertures, and the decreasing lumina towards the colpi are common characteristics. They differ, however, in colpus length and overall size. Despite this strong relationship, especially with the Cymosum group, the $D$. heudelotii type is kept a better entity if the $D$. crassifolium type is left out. 
D. echinulatum specimens are very variable. The specimen Le Testu 5910 belongs to the $D$. crassifolium type in all its features. The specimen Breteler 6694 differs by having a fine, indistinct reticulum, but the pollen grains are not quite mature and for this reason the ornamentation may not be complete. On the other hand, the long colpi and rather large overall size keeps the specimen distinctly in the $D$. crassifolium type. The specimen Mildbread 7816 differs by having rather short colpi, but in this specimen the absence of interrupted muri and the large overall size are features in favour of keeping the specimen in the $D$. crassifolium type. Although the specimens of $D$. echinulatum show some resemblance to the $D$. heudelotii type, to which $D$. staudtii and $D$. contractum belong, they differ too much to unite them.

\section{Dichapetalum gelonioides type (Plates VI, VII, VIII)}

Pollen class: 3-Colporate, sometimes 4-colporate.

$P /$ E ratio: Oblate.

Apertures: Apertures sometimes protruding (e.g. Gelonioides group). Ectoapertures - colpi, usually short, sometimes rather long ( $D$.

helferianum), rather narrow to narrow, often slightly broadened at the equatorial plane, often slightly sunken, usually with rounded ends, sometimes acute; margins distinct; costae sometimes present. Endoapertures pori, either circular or lalongate, distinct or indistinct, large; sometimes with costae, faint nexine thickenings along the endoaperture beneath the ectocolpus.

Exine: Thin. Sexine about as thick as nexine. Columellae indistinct and short; capita small and usually elongated sideways, otherwise circular in outline.

Ornamentation: Pollen grains tectate or microreticulate. Muri thick, usually thicker than lumina width, sometimes as thick as the lumina; not interrupted. Lumina irregular in shape, not decreasing towards the colpi. Sometimes in the sexine a loose reticulation of narrow grooves present at the poles (Sumatranum group). If pollen grains tectate, numerous perforations present. Outlines: Polar view - triangular; sides straight to slightly convex, sometimes distinctly convex; angles always obtuse; colpi situated in the angles, sometimes slightly sunken. Equatorial view - elliptic or rectangular; if the outline is rectangular then the long sides slightly concave (sunken poles), otherwise long sides convex; short sides obtuse if the mesocolpium is seen in optical section and acute with rounded acumens if the colpus is seen in optical section.

Measurements: $\mathrm{P} 10-22 \mu ; \mathrm{E} 14-33 \mu ; \mathrm{P} / \mathrm{E}$ ratio $0.55-0.74$, usually in the range of $0.60-0.70$. Exine ca. $1 \mu$ thick, sometimes slightly thicker. Lumina smaller than $1 \mu$, rarely up to $1 \mu$ (Andamanicum group).

Species: D. gelonioides ssp. andamanicum, D. gelonioides ssp. gelonioides, $D$. gelonioides ssp. pilosum, D. gelonioides ssp. sumatranum, D. gelonioides ssp. tuberculatum, $D$. helferianum 
Key to the pollen groups

1.a. Grains small ( $E$ not exceeding $22 \mu$ ); endoapertures without costae; ornamentation tectate to microreticulate . . . . . . . . . 2

b. Grains rather large to large (E not less than $20 \mu$, usually more than $22 \mu$ ); endoapertures often with slight costae; ornamentation

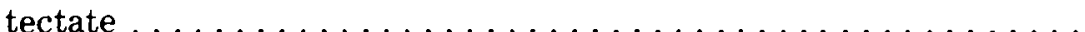

2.a. Colpus rather long; ends acute; ornamentation tectate to microreticulate; endoapertures lalongate.......... Helferianum group

b. Colpus short, ends more or less rounded; ornamentation tectate or microreticulate; endoapertures variable in outline . . . . . . . 3

3.a. Microreticulate; apertures not protruding; endoapertures

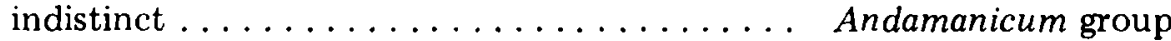

b. Tectate; apertures usually slightly protruding; endoapertures , distinct or indistinct.................... 4

4.a. Usually grooves in sexine at apocolpium; endoaperture indistinct . . ................... Sumatranum group

b. No grooves in sexine; endoaperture distinct, circular ..................... Pilosum group

5.a. Endoaperture with distinct margins, lalongate; colpus short, ends rounded ................... Gelonioides group

b. Endoaperture with indistinct margins; colpus short to rather long, ends rounded to acute ............. Tuberculatum group

\section{Comment}

The $D$. gelonioides type is reasonably homogeneous, its basic features are fairly constant, and pollen grains belonging to it can easily be recognized. The most important diagnostic feature is the ornamentation which varies from a microreticulum to a tectum perforatum (Andamanicum group). Another constant character is the overall shape although the outline in either view may vary slightly. Many other features such as colpus length, the outline of the endoaperture, the distinctness of the endoaperture can vary considerably. Most of the groups show one special feature by which they are easily distinguished and because of this the $D$. gelonioides type is split into several groups. It is striking that these morphological pollen groups are in complete accord with the taxonomic subspecies which Leenhouts established in his treatment of $D$. gelonioides (Leenhouts, 1956). The only exception is that Leenhouts accepted $D$. helferianum as a separate species whereas its pollen grains undoubtedly belong to the $D$. gelonioides type.

The Andamanicum type shows no special features in its basic set of characteristics. In fact this group does not show any particular feature to separate it from the others, and it is a combination of characteristics which differentiate the Andamanicum group. The most important difference is found in the ornamentation. The lumina are usually of the same width as the muri. The group most resembles the Sumatranum group and the Helferianum group. 
The Sumatranum group is characterized by the presence of narrow grooves in the ornamentation at the apocolpium. These grooves form an irregular large-mesh negative reticulum in the sexine (Plate VI, 6, 7). The sexine 2 is a tectum with many perforations which is slightly sunken at the poles. In other features the pollen grains are very much like those of the Andamanicum group. In overall size and polar view outline the group resembles the Pilosum group but this differs in its characteristic endoaperture outline.

The Pilosum group is easily recognized by its distinct, circular endoaperture, a special feature of the group. Because of the outline in polar view the pollen grains closely resemble those of the Sumatranum group and this latter group is the only one which can be compared with the Pilosum group to any degree.

The Helferianum group has pollen grains which show a slight resemblance to both the Gelonioides group and the Tuberculatum group. The Gelonioides group, however, has short colpi with rounded ends and the grains of the Tuberculatum group are much larger. On the other hand, the $\mathrm{Hel}$ ferianum group shows a slight similarity in its ornamentation with the Andamanicum group. Some resemblance to the Sumatranum group cannot be denied, but this is differentiated by its grooves in the reticulum at the apocolpium.

The Gelonioides group is distinguished by the following features: (1) Endoapertures distinct, large and lalongate. This is the most striking differentiating characteristic which is also shown by the Helferianum group, but in this latter group the colpi are longer, narrow, and with acute ends. (2) Large pollen grains. The Tuberculatum group is the only one with grains as large as or even larger than those of the Gelonioides group.

The Tuberculatum group most resembles the Gelonioides group, particularly in the size of the pollen grains and in the small costae which run along the endoapertures under the colpi. Striking differences are, however: (1) colpi longer and with more or less acute ends; and (2) endoapertures less distinct.

9. Dichapetalum gilletii type (Plate VIII, 9-14; Plate IX, 1-5; Plate XX, 4)

Pollen class: Inaperturate or 3-colporate.

$P / E$ ratio: Suboblate or oblate.

Apertures: Ectoapertures - sometimes absent (Pedicellatum group); if present, usually small, narrow or broad colpi, if broad then indistinct and with rounded ends, if narrow then with acute ends; margins distinct or indistinct; distinct margo can be present, often interrupted; no costae. Endoapertures - porus-like, indistinct, large, usually almost circular, but sometimes lalongate or lolongate; no costae.

Exine: Usually of normal thickness (ca. $1 \mu$ ), sometimes distinctly thicker. Sexine usually about as thick as nexine, sometimes slightly thicker or 
thinner. Columellae short and indistinct; capita circular to slightly elongated in outline; size varying.

Ornamentation: Pilate or rarely verrucate. Elements irregularly arranged, all over the grain; outline of elements in surface view varying from small and circular to large and irregular.

Outlines: Polar view - triangular; sides slightly convex; angles obtuse. Equatorial view - elliptic; long sides convex; short sides convex.

Measurements: $\mathrm{P} 15-23 \mu ; \mathrm{E} 19-27 \mu ; \mathrm{P} / \mathrm{E}$ ratio $0.67-0.92$, usually in the range of $0.75-0.85$. Exine usually $1 \mu$ thick, sometimes up to $2 \mu$. Diameter of the pila usually smaller than $1 \mu$, sometimes up to $3 \mu$.

Species: Gilletii group: $D$. acuminatum, $D$. altescandens p.p. (Le Testu 7183), D. gilletii

Pedicellatum group: D. altescandens p.p. (Hallé 1959), D. pedicellatum Reticulatum group: $D$. beilschmidioides, $D$. reticulatum, $D$. umbellatum

Key to the pollen groups

1.a. Pollen grains inaperturate (without colpi), exine rather thick (up to $2 \mu$ ), no margo; pila coarser than other groups . .... Pedicellatum group

b. Pollen grains colporate; exine less thick (ca. $1 \mu$ ); pila less coarse than in the foregoing group $\ldots \ldots \ldots \ldots \ldots \ldots \ldots \ldots . \ldots \ldots$

2.a. Margo absent ................... Gilletii group

b. Margo present................... Reticulatum group

\section{Comment}

The $D$. gilletii type is one of the easiest to recognize. The prominent pilate ornamentation is only met again in the $D$. mundense type, but in that case the pila are much smaller and less distinct. In addition, the outline in polar and in equatorial view is uncommon among the Dichapetalum types, this kind of overall shape is only present in pollen grains of the D. mundense type and some species in the Pallidum group of the $D$. angolense type ( $D$. brazzae, $D$. pallidum). Within the $D$. gilletii type the pollen grains show a distinct differentiation in some features and for this reason a further division of the type has been proposed, although the differential characteristics are sometimes slight and intergrading. In the Gilletii group, $D$. acuminatum and $D$. altescandens (Le Testu 7183) show distinct, rather broad colpi, whereas $D$. gilletii itself has narrow, indistinct colpi and is transitional to the Pedicellatum group with inaperturate grains. The latter group, however, also differs by having a thicker exine and a slightly coarser pilate ornamentation.

A specific and constant feature of the Reticulatum group is the distinct margo to the colpi and it could be suggested that the group should form a separate type, but the pilate ornamentation and the overall shape are so characteristic of the $D$. gilletii type and so unusual in the Dichapetalaceae that it seems better to retain both groups in the same type. 


\section{Dichapetalum grandifolium type (Plate IX, 6-10)}

Pollen class: 3-Colporate, sometimes 4-colporate. $P / E$ ratio: Oblate.

Apertures: Apertures slightly or not protruding. Ectoapertures - colpi, short to rather long, narrow, slightly broadened in the equatorial plane; ends acute to slightly rounded; not or only slightly sunken; margins distinct; no costae; a fastigium may be present. Endoapertures - pori, large, lalongate, usually indistinct; margins diffuse; no costae. Operculum sometimes present $(D$. steenistii).

Exine: Exine thick. Sexine about as thick as nexine or slightly thicker. Columellae short and indistinct; capita indistinct.

Ornamentation: Tectate. Tectum usually without perforations or with a few very small ones.

Outlines: Polar view - triangular; usually sides slightly convex, sometimes slightly "yoke-like" because of the protruding apertures; angles obtuse. Equatorial view - elliptic; long sides parallel, poles not distinctly sunken; short sides with one colpus in optical section have a pear-shaped outline, if, however, both mesocolpia in optical section, then the outline is elliptic with two obtuse acumina.

Measurements: $\mathrm{P} 10.5-17.5 \mu ; \mathrm{E} 15-26 \mu ; \mathrm{P} / \mathrm{E}$ ratio $0.58-0.72$. Exine at least $1.5 \mu$ and up to $2 \mu$ thick.

Species: $D$. grandifolium, $D$. setosum, $D$. steenisii

\section{Comment}

The $D$. grandifolium type is similar to the $D$. gelonioides type and they might be united were it not for the completely closed, pertectate sexine which is imperforate or has only a few indistinct perforations. This feature seems sufficiently important that it is justifiable to keep the types separate. Moreover, if they are brought together in the $D$. gelonioides type, it becomes heterogeneous, whereas a separation of the types gives two homogeneous units.

The pollen grains most resemble those of the Gelonioides group, because of their large overall size, polar and equatorial view outlines. The features of the apertures, ectoapertures as well as endoapertures, are different.

One specimen of the species $D$. steenisii (Kostermans 21575 from Borneo) is unusual in its small size and particularly in its lack of protruding apertures which alters the outline considerably. Its exine is, however, pertectate and because this feature is considered so significant the species has been kept in this type.

11. Dichapetalum heudelotii type (Plate IX, 11-15; Plate X, 1-13, 23-25; Plate XX, 3)

Pollen class: 3-Colporate, rarely inaperturate (i.e., without ectoapertures); some specimens show a low percentage of 4-colporate pollen grains and 
rarely 2-colporate grains occur.

$P / E$ ratio: Oblate, rarely peroblate.

Apertures: Ectoapertures - colpi, usually short, often very short, rarely rather long, narrow, often slit-like, slightly or not sunken; ends acute; margins indistinct to more or less distinct; no costae. Endoapertures indistinct; small; if faintly visible usually circular in outline, sometimes slightly lalongate (Unguiculatum group); no costae.

Exine: The exine varies from very thin to thin. The sexine varies from slightly thinner to slightly thicker than the nexine. Columellae usually short and indistinct, sometimes more or less distinct (Unguiculatum group); capita small, circular in outline.

Ornamentation: Reticulate to microreticulate. Reticulum varying from coarse to fine at the poles. Muri thin, never thicker towards the base; usually distinctly interrupted at the poles, sometimes only slightly interrupted and rarely not interrupted at all. Lumina irregular in shape; distinctly decreasing towards the colpi and usually also towards the equatorial plane.

Outlines: Polar view - triangular; sides slightly convex to nearly straight, rarely distinctly convex; angles subacute. Equatorial view - elliptic; long sides al ways concave (sunken poles); short sides either obtuse if the mesocolpia, or acute if the colpus is seen in optical section.

Measurements: P $5-11 \mu$, usually between 7 and $10 \mu ; \mathrm{E}$ usually between 10 and $15 \mu ; \mathrm{P} / \mathrm{E}$ ratio $0.45-0.74$, usually between 0.50 and 0.70 . Exine ranging from ca. $0.5 \mu$ (very thin) to slightly thicker than $1 \mu$ (thin). Lumina at the poles varying from ca. $1 \mu$ to ca. $3 \mu$; towards the colpi and equatorial plane lumina usually smaller than $1 \mu$.

Key to the pollen groups

1.a. Sexine/nexine ratio greater than 1 ; columellae distinct; endoaperture lalongate, if visible; colpi short to rather long; reticulum distinct; exine thin ........... Unguiculatum group

b. Sexine/nexine ratio ca. 1 or smaller than 1 ; columellae indistinct; endoaperture, if visible, circular; colpi short to very short; reticulum indistinct to distinct and very coarse . . . . . 2

2.a. Reticulum very coarse; colpi very short; sexine/nexine ratio ca. 1; exine thin..................... Cymulosum group

b. Reticulum indistinct to distinct, but not very coarse; colpi short; sexine/nexine ratio ca. 1 to smaller than $1 \ldots \ldots \ldots$. Heudelotii group Species: Cymulosum group: D. cinereo-viride, D. cymulosum, $D$. dictyospermum, $D$. filicaule, $D$. oblongum

Heudelotii group: $D$. bodyi, D. congoense, D. contractum, D. germainii, $D$. glomeratum, $D$. heudelotii, $D$. hispidum, $D$. insigne, $D$. longitubulosum, $D$. martineaui, $D$. minutiflorum, $D$. montanum, $D$. ndongense, $D$. obanense, $D$. oliganthum, $D$. pallidinervum, $D$. pulchrum, $D$. staudtii, $D$. subauriculatum, D. zenkeri (p.p. Dale 3862, Graham 2132, Le Testu 7615, Le Testu 8526)

Unguiculatum group: D. corrugatum, D. eickii, D. tomentosum, D. unguiculatum 
Two species probably belonging to the $D$. heudelotii type, but differing slightly from the basic diagnosis of the pollen grains are:

D. cuneifolium: In equatorial view the long sides not concave, i.e. the poles are not sunken. Besides this, the pollen grains are sometimes 2 -colporate or 4-colporate.

$D$. white $i$ : The pollen grains are rather large and in this they resemble the $D$. crassifolium type. The lumina of the reticulum are, however, extremely fine and do not distinctly decrease in size towards the colpi; the muri are not or only slightly fractured.

\section{Comment}

The $D$. heudelotii type comprises many species and the pollen grains show great variability. Nevertheless the type is rather easy to distinguish by a combination of features; these are: (1) Outline of the pollen grains triangular, subacute; i.e. the sides are slightly convex to nearly straight up to the angles, and only the very angle is slightly obtuse. (2) In equatorial view the long sides are always concave (sunken poles). (3) The colpi are short or very short and only in rare cases rather short to rather long. Ectocolpi usually very narrow. (5) Endoapertures indistinct, and if faintly visible, al ways small. (6) Lumina of the reticulum decreasing towards the colpi (angles). (7) Muri of the reticulum usually distinctly interrupted at the poles.

Pollen grains which most resemble those of the $D$. heudelotii type are found in the Angolense group of the $D$. angolense type which is very similar in the following features: (1) the outline in polar view; (2) sunken poles; and (3) interrupted muri. In the $D$. angolense type, however, the reticulum does not decrease towards the colpi (angles), the colpi are indistinct or even absent, and the endoaperture in most pollen grains is more or less distinct.

The Heudelotii group is mainly characterized by its very thin or thin exine, indistinct, circular endoporus and a sexine/nexine ratio of about 1 or smaller than 1 . Usually the reticulum is less distinct than in the following two groups. The Heudelotii group is not homogeneous and is variable in most of its characteristics. In practice, all pollen grains which do not belong clearly to one of the other two groups fall into the Heudelotii group. It was not possible to give a further consistent differentiation within this latter group.

The Unguiculatum group is mainly differentiated from the other groups by its exine characters. The most striking feature is the distinct reticulum formed by the relative thick sexine which is slightly thicker than the nexine. The second feature is difficult to see but rather remarkable. According to the definition of the $D$. heudelotii type all specimens show an indistinct endoaperture, but the faint margins in the Unguiculatum always have a lalongate outline, whereas the outlines in the other groups are either circular or indiscernable. The third feature, the absence of very short colpi, is not so specific to this group as it occurs elsewhere in the $D$. heudelotii type.

The pollen of $D$. eickii is similar, but not identical to that of this group. 
Its reticulum is distinct and the sexine certainly not thinner than the nexine, but on the other hand the sexine is not distinctly thicker than the nexine, a feature so characteristic for this group. Also the faint margins of the endoaperture are circular in outline, which is an important difference. The pollen grains of this species are intermediate between those of the Cymulosum group and of the Unguiculatum group.

There is no doubt that the Cymulosum group belongs to the $D$. heudelotii type; the main characteristics of polar view outline, indistinct endoaperture and interrupted muri, are present. The group, however, shows some remarkable features which differentiate it from the species of the Heudelotii group. The most striking features is the distinct, very coarse reticulum at the poles. As in the Unguiculatum group the sexine is at least as thick as the nexine, but in most specimens the sexine is slightly thicker than the nexine. In addition, there are several ciher characters which are fairly constant in this group: (1) The colpi are very short and sometimes nearly absent. The margins are less distinct than in the other groups. (2) Unlike the Unguiculatum group the endoaperture is completely indistinct in this group. (3) The lumina in the equatorial plane are rather large (ca. $1 \mu$ or slightly smaller). (4) The sides in polar view are only slightly convex to nearly straight. Together with the subacute angles these two features give the pollen grains a distinctly triangular outline in polar view.

\section{Dichapetalum pedunculatum type (Plate XIII, 9-15)}

Pollen class: 3-Colporate.

$P / E$ ratio: Oblate.

Apertures: Apertures more or less protruding. Ectoapertures - colpi, varying from short to rather long, very narrow (slit-like), not or slightly sunken; ends acute; margins usually indistinct, sometimes distinct; no costae. Endoapertures - pori, circular or slightly lalongate, large, margins rather indistinct; no costae.

Exine: Thin. Sexine about as thick as nexine, sometimes slightly thicker or thinner. Columellae short, indistinct; capita small, circular in outline. Ornamentation: Usually tectate with numerous perforations, sometimes microreticulate. Muri thin; not interrupted. Lumina irregular in shape, not decreasing towards the colpi or the equatorial plane.

Outline: Polar view - triangular; the sides "yoke-like" in appearance because of the protruding apertures, slightly convex in the middle part; angles obtuse. Equatorial view - elliptic; long sides usually concave (sunken poles). Measurements: P 8-13 $;$ E $13-19 \mu ; \mathrm{P} / \mathrm{E}$ ratio $0.60-0.75$. Exine ca. $1 \mu$ thick.

Species: D. axillare, D. cubensis, D. froesii, D. latifolium, D. odoratum, $D$. pauper, D. pedunculatum, $D$. rugosum, $D$. spruceanum

\section{Comment}

The pollen grains of all species in the $D$. pedunculatum type resemble each other very closely and the only clear variations are found in the 
ornamentation, and to some extent in the length of the colpi. The tectum varies from almost invisibly perforate ( $D$. pedunculatum) to distinctly microreticulate (D. spruceanum). It is possible to make a complete morphological series between these extremes, there is no sharp delimitation. Since this is the only character which varies between species to any extent, it is not possible to create pollen groups in the American species of Dichapetalum; they all fall into one homogeneous type.

The $D$. pedunculatum type is in many characteristics very like the $D$. angolense type and it is rather difficult to separate them. The most striking difference is found in the tectate ornamentation: most pollen grains of the $D$. pedunculatum type have a tectum with numerous perforations. A few species, however, have microreticulate grains (D. latifolium, $D$. spruceanum) and their pollen grains are less easily differentiated from the $D$. angolense type. There are further differences between the two types, but these are less striking. The slightly protruding apertures are not present in the $D$. angolense type and this can provide a differential, but this is only apparent in completely mature grains. Another feature which is difficult to use for differentiation is the short to rather long colpi with more or less distinct margins. Again, sunken poles are features not common in the $D$. angolense type, but they occur now and then.

One might wonder whether it is not better to place the $D$. pedunculatum type in the $D$. angolense type as a separate group, but as with the $D$. grandifolium type, this author would like to keep the type apart because of the tectate condition of the sexine. Both types are very closely related, of course, and in a natural system the units must be placed together.

\section{Dichapetalum leucosia type (Plate $X, 14-22$ )}

Pollen class: Inaperturate; i.e. without ectoapertures. Endoapertures present; usually $3-$, rarely 4 -endoapertures.

$P / E$ ratio: Oblate.

Apertures: Ectoapertures - absent. Endoapertures - pori, small and indistinct, usually circular, sometimes slightly lalongate; no costae.

Exine: Thin. Sexine about as thick as nexine. Columellae short, indistinct; capita small, circular in outline.

Ornamentation: Reticulate to microreticulate. Reticulum varying from fine to rather coarse. Muri thin at poles, sometimes slightly thicker towards the equatorial plane and the base; interrupted or not. Lumina irregular in shape, distinctly decreasing towards the endoapertures and the equatorial plane. Outlines: Polar view - usually distinctly triangular, sometimes nearly circular; sides usually distinctly convex, sometimes slightly convex; angles obtuse. Equatorial view - elliptic; long sides sometimes not concave ( $D$. bojeri) but often distinctly concave (sunken poles); short sides obtuse if mesocolpia in optical section and acute if one colpus is seen in optical section.

Measurements: $\mathrm{P} 7-12.5 \mu ; \mathrm{E} 11-19 \mu ; \mathrm{P} / \mathrm{E}$ ratio $0.50-0.77$, usually in the 
range of $0.60-0.70$. Exine ca. $1 \mu$ thick. Lumina at the poles varying from $1 \mu$ up to $2.5 \mu$; in the equatorial plane usually less than $1 \mu$ in diameter.

Key to the groups

1.a. Pollen grains without sunken poles; reticulum not interrupted.................... Bojeri group

b. Pollen grains with distinct sunken poles; reticulum interrupted $\ldots \ldots \ldots \ldots \ldots \ldots \ldots \ldots \ldots$ Leucosia group Species: Bojeri group: D. bojeri, D. vondrozanum (?, intermediate) Leucosia group: D. leucosia, D. nigrescens, D. oleifolium, D. perrieri, D. virchowii

\section{Comment}

The $D$. leucosia type is homogeneous with regard to some striking characters e.g. the absence of ectoapertures and the outline in polar view. On the other hand, several other characters vary considerably. The muri of the reticulum may be either continuous or distinctly interrupted, and the outline in equatorial view varies from elliptic with convex long sides to elliptic with distinctly concave long sides (sunken poles). This variability makes it difficult to give precise delimitations between the groups.

The pollen grains of the $D$. leucosia type show features, such as the absence of ectoapertures, and outline in polar view, which do not occur commonly in the other African types. The pollen grains most resembling those of the $D$. leucosia type are Asian, viz. the $D$. papuanum type, with short but indistinct ectoapertures and the $D$. timoriense type which is also without ectoapertures. In addition, the latter type shows the characteristic outline in polar view. Both types, however, differ from the D. leucosia type in having a continuous reticulum which never decreases towards the equatorial plane or to the angles. Moreover, the lumina of the reticulum are usually very fine (microreticulum), sometimes tending towards a tectum perforatum.

In Africa the pollen grains of $D$. ruhlandii of the $D$. barteri type resemble those of the $D$. leucosia type because of the absence of ectoapertures and because of the similarity in outline. However, the reduced sexine makes it clear that $D$. ruhlandii belongs to the $D$. barteri type, and the identical outline and absence of ectoapertures must be considered an example of parallel development.

\section{Dichapetalum longipetalum type (Plate XI, 1-9)}

Pollen class: 3-Colporate, sometimes inaperturate (Tonkinense group). $P / E$ ratio: Oblate, rarely suboblate.

Apertures: Ectoapertures - colpi, usually short, narrow, not broadened in the equatorial plane, not sunken; ends acute; margins distinct; apertures sometimes absent. Endoapertures - pori, indistinct, probably circular, small; no costae.

Exine: Exine thin. Sexine about as thick as nexine or slightly thicker. 
Columellae short and indistinct; capita small, nearly circular in outline. Ornamentation: Reticulate. Reticulum coarse at the poles and distinctly finer near the colpi and in the equatorial plane. Muri thin, slightly thickened towards the base; slightly to distinctly interrupted at the poles. Lumina irregular, usually angular in shape; always distinctly decreasing to wards the colpi and the equatorial plane.

Outlines: Polar view - triangular; sides slightly to distinctly convex; angles subacute. Equatorial view - elliptic; long sides usually concave (sunken poles); short sides obtuse.

Measurements: $\mathrm{P} 10-13 \mu ; \mathrm{E} 14-19 \mu ; \mathrm{P} / \mathrm{E}$ ratio $0.61-0.76$, usually in the range of $0.65-0.75$. Exine ca. $1 \mu$ thick. Lumina varying at the poles from $2 \mu$ up to $6 \mu$ and in the equatorial plane from $1 \mu$ to $2 \mu$.

Key to the groups

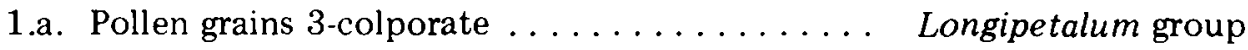

b. Pollen grains inaperturate ............. Tonkinense group

Species: Longipetalum group: $D$. griffithii, D. longipetalum, D. laurocerasus Tonkinense group: D. longipetalum p.p. (Balansa 3328, SYNTYPE of $D$. tonkinense Engler)

\section{Comment}

The pollen grains of the $D$. longipetalum type are without doubt morphologically related to the $D$. heudelotii type. The two types have several features in common: (1) the outline in polar view; (2) short indistinct colpi (rarely inaperturate); (3) muri interrupted at the apocolpium; (4) lumina distinctly decreasing towards the colpi and the equatorial plane; and (5) poles sunken. It is not easy to differentiate between the two types, but the striking coarse reticulum at the poles together with the feature of the thicker muri towards the base, keep the types apart.

The D. madagascariense type is similar in that its muri are thicker towards the base, but its sexine distinctly thinner than the nexine, a feature which is certainly absent in the $D$. longipetalum type.

The Tonkinense group is distinctly separated from the Longipetalum group by the absence of ectocolpi, but some other facts have to be considered: (1) The group is based on one specimen only. It is quite possible that transitional specimens exist, but these were none among the specimens examined. (2) As in other Dichapetalum types, the occurrence of inaperturate pollen grains together with 3-colporate ones is not uncommon, viz. $D$. angolense type, $D$. heudelotii type. It therefore seems best to keep both groups in one pollen type.

15. Dichapetalum macrocarpum type (Plate XI, 10-13)

Pollen class: 3-Colporate.

$P / E$ ratio: Oblate, rarely suboblate. 
Apertures: Ectoapertures - colpi, very short, narrow, not or only slightly sunken; ends acute to slightly rounded; margins indistinct; no costae. Endoapertures - pori, large, indistinct; no costae.

Exine: Exine rather thick. Sexine thicker than nexine. Columellae short and indistinct; capita more or less circular in outline.

Ornamentation: Reticulate. Reticulum coarse to rather coarse. Muri relatively thick, probably simplicolumellate, but indistinct in surface view; not interrupted. Lumina irregular in shape, slightly decreasing towards the colpi, but not markedly decreasing towards the equatorial plane.

Outlines: Polar view - triangular; sides straight to slightly convex; angles obtuse. Equatorial view - elliptic; long sides convex; short sides convex.

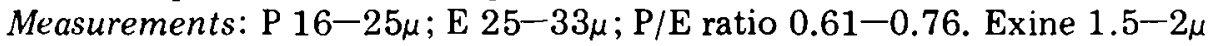
thick. Lumina of the reticulum usually ca. $2 \mu$ in diameter, sometimes up to $2.5 \mu$.

Species: D. macrocarpum

\section{Comment}

The pollen grains of this type have a close affinity with the pollen grains of $D$. pallidum of the $D$. angolense type. It might be possible to unite the type with the Pallidum group since the outlines in polar view as well as in equatorial view are remarkably similar. On the other hand, the overall size is much larger (the $\mathbf{P}$ and $\mathrm{E}$ measurements are the largest in the Dichapetalaceae), the sexine is between 1.5 and $2 \mu$ thick, while most other pollen grains in Dichapetalum have an exine of ca. $1 \mu$ or even thinner, and the sexine is distinctly thicker than the nexine. Moreover, the ectoaperture differs considerably, being broad and large in $D$. pallidum and short and narrow in $D$. macrocarpum. Particularly for these latter two features but also because of the other differences the type has been separated from the Pallidum group.

\section{Dichapetalum mombuttense type (Plate XI, 14; Plate XII, 1-6)}

Pollen class: 3-Colporate.

$P /$ E ratio: Oblate to peroblate.

Apertures: Ectoapertures - colpi, varying from short to rather long, always very narrow at the ends and slightly broadened at the equator, not sunken; ends acute; margins distinct; no costae. Endoapertures - pori, indistinct, circular to lalongate, usually small; no costae.

Exine: Exine thin. Sexine about as thick as nexine or slightly thicker. Columellae short and indistinct; capita very small, circular in outline. Ornamentation: Pilate at the poles, and microreticulate or tectate in the equatorial plane. At the apocolpium the sexine is distinctly fragmentated into small sexine elements (pila), sometimes united into short muri. Muri thin to slightly thickened towards the base. Lumina rapidly decreasing towards the colpi and the equatorial plane, sometimes forming a microreticulum; in other specimens the ornamentation is a tectum with perfora- 
tions and in one species (D. affine) a completely closed tectum has been observed.

Outlines: Polar view - triangular; sides slightly to distinctly convex; angles subacute. Equatorial view - elliptic; longest sides distinctly concave (sunken poles); short sides convex if the mesocolpia are in optical section and acute if the colpus is seen in optical section.

Measurements: $\mathrm{P} 6-9 \mu ; \mathrm{E} 11.5-15.5 \mu ; \mathrm{P} / \mathrm{E}$ ratio $0.45-0.67$, usually in the range of $0.55-0.65$. Exine ca. $1 \mu$ thick or slightly thinner.

Species: $D$. affine, $D$. mombuttense, $D$. pierrei, $D$. rudatisii, $D$. toxicarium

\section{Comment}

The $D$. mombuttense type is a homogeneous one and the pollen grains in this type are very much alike. The distinctly fragmentated sexine, the small endoapertures, narrow colpi, and the distinctly sunken poles point to a close relationship with the $D$. heudelotii type. Some characteristics, however, are so different that it seems justified to keep the type apart.

The most important differentiating characteristics of this type are: (1) The outline in polar view usually shows distinctly convex sides and sometimes slightly convex sides, but never nearly straight sides. (2) The muri at the poles (apocolpium) are extremely interrupted, leaving little trace of a reticulum. The area is beset with scattered pila and sometimes with short muri. Towards the equatorial plane the ornamentation rapidly changes into a very fine reticulum (microreticulum) or tectum. (3) The ornamentation is distinct because the sexine is at least as thick as the nexine. (4) The P/E ratio, although not very different from that of the $D$. heudelotii type, is slightly smaller (distinctly oblate to peroblate).

\section{Dichapetalum mundense type (Plate XII, 7-10)}

Pollen class: Inaperturate, i.e. without ectoapertures; however, endoapertures present.

$P / E$ ratio: Oblate, sometimes suboblate.

Apertures: Ectoapertures - absent. Endoapertures - pori; usually 3, rarely 4 per grain; shape irregular, large, usually more or less circular; no costae.

Exine: Thin. Sexine distinctly thinner than nexine. Columellae short, indistinct; capita small, more or less circular in outline.

Ornamentation: Pilate. Sexine elements pilum-like to granular; size small; number of elements large; arrangement inordinate and crowded; in surface view outline more or less circular.

Outlines: Polar view - triangular; usually slightly convex, rarely distinctly convex; angles obtuse. Equatorial view - elliptic; long sides distinctly convex; short sides obtuse.

Measurements: $\mathrm{P} 10-19 \mu ; \mathrm{E} 14-24 \mu ; \mathrm{P} / \mathrm{E}$ ratio $0.66-0.79$. Exine usually thinner than $1 \mu$, up to $1 \mu$ (D. bellum).

Species: $D$. bellum, $D$. mundense 


\section{Comment}

The $D$. mundense type shows a striking resemblance to the $D$. gilletii type. The most important difference is that the sexine is distinctly thinner than the nexine and consequently the ornamentation appears rather vague. 'The sexine consists of single elements (pila), just as in the $I$ ). gilletii type, but the shape of the elements is smaller and less clear, moreover the $I$ ). munclense type has many more of these elements than does the I). gilletii type. As in the Pedicellatum group of the latter type the pollen grains in the D. mundense type are inaperturate.

D. bellum differs from $D$. mundense in its thicker exine $($ ca. $1 \mu)$ and slightly greater overall size (E up to $24 \mu$ ).

\section{Dichapetalum papuanum type (Plate XII, 11-16; Plate XIII, 1-3)}

Pollen class: 3-Colporate, rarely 1-colporate.

$P / E$ ratio: Lisually suboblate, less commonly oblate.

Apertures: Ectoapertures - colpi, very short, narrow, not sunken; ends acute; margins diffuse, rather indistinct; no costae. Endoapertures - pori, small and indistinct, probably circular; no costae.

Exine: Exine relatively thick. Sexine about as thick as nexine or slightly thicker. Columellate short and usually more or less distinct; capita al most circular in outline or slightly elongated sideways.

Ornamentation: Reticulate. Reticulum fine to coarse. Nuri thin or thick. sometimes slightly thicker towards the base; not interrupted or, in specimens with thick muri, rarely slightly interrupted. Lumina irregular, not decreasing towards the colpi.

Outlines: Polar view - triangular to circular; if pollen grains triangular, sides distinctly convex; angles obtuse; colpi situated in the middle of the sides. Equatorial view - elliptic, sometimes rectangular; sides convex, angles obtuse; long sides distinctly convex (poles not sunken).

Measurements: P $11-17 \mu ; \mathrm{E} 11-21 \mu ; \mathrm{P} / \mathrm{E}$ ratio $0.67-0.92$. Usually in the range of $0.75-0.88$. Fxine ca. $1 \mu$ thick up to $1.5 \mu$ thick. Lumina of the reticulum ca. $1 \mu$ wide, up to $3 \mu$ in some specimens.

Species: 1). papuanum, 1). sessiliflorum, D. Hicapsulare, D). vitiense'

\section{(omment}

The 1 . papuanum type is a homogeneous types. its differentiating characteristic's are as follows: (1) short colpi with rather vague margins; (2) PiE ratio larger than most of the other Dichapetalum types (usually suboblate); (3) exine rather thick; (1) reticulum distinct; and (5) apocolpium not sunken. In many respects the type resembles the I). timoriense type which differs in several characteristics (ectoapertures absent, apocolpium sunken). On the other hand, the endoaperture in the 1 . papuanum type is small and indistinct, a character which is not always present in all groups of thes

I). timoriense type.

The outlines and omanentation of the pollen grains in the 1 ). papuamum 
type are intermediate between the $D$. bangii type and the other types. In fact the ornamentation of the $D$. bangii type and the $D$. papuanum type are very much alike. For a further comment on the general relationship of this interesting type with other types see p. 55 .

\section{Dichapetalum parvifolium type (Plate XIII, 4-8)}

Pollen class: 3-Colporate.

$P / E$ ratio: Suboblate, rarely oblate.

Apertures: Ectoapertures - colpi varying from short to long, very narrow (slit-like), not sunken; ends acute, distinct margins; not broadened in the equatorial plane. Endoapertures - pori, indistinct; small, probably circular; no costae.

Exine: Exine thin. Sexine about as thick as nexine. Columellae short, indistinct; capita small, circular in outline.

Ornamentation: Reticulate to microreticulate. Reticulum fine. Muri thin to rather thick, but not thicker towards the base; not interrupted. Lumina irregular in shape, not decreasing towards the colpi nor towards the equatorial plane.

Outlines: Polar view - triangular; sides straight to slightly convex; angles obtuse to slightly subacute. Equatorial view - elliptic, if mesocolpia seen in optical section; pear-shaped if the outline shows one colpus in optical section. Measurements: $\mathrm{P} 10-15 \mu ; \mathrm{E} 14-19 \mu ; \mathrm{P} / \mathrm{E}$ ratio $0.74-0.85$. Exine ca. $1 \mu$ thick. Lumina ca. $1 \mu$ wide or less.

Species: $D$. parvifolium

\section{Comment}

The $D$. parvifolium type is in many respects similar to the $D$. angolense type, e.g. by its fine reticulum without interrupted muri, not decreasing lumina and by the outline in polar view. The most important difference is, however, the distinct margins along the usually rather long to long colpi. Moreover, the $\mathrm{P} / \mathrm{E}$ ratio is not as small. In fact the type is intermediate in its $\mathrm{P} / \mathrm{E}$ ratio between the spheroidal $D$. bangii type and most other Dichapetalum types.

\section{Dichapetalum thollonii type (Plate XIII, 16, 17; Plate XIV, 1-6)}

Pollen class: 3-Colporate.

$P / E$, ratio: Oblate.

Apertures: Ectoapertures - colpi short to rather long, narrow, but slightly broader at the equatorial plane, not sunken; ends acute; margins rather indistinct; no costae. Endoapertures - pori, indistinct, rather large, circular. Exine: Thin. Sexine about as thick as nexine, certainly not distinctly thinner Columellae short, indistinct; capita small, more or less circular in outline. Ornamentation: Reticulate. Reticulum very coarse at the poles. Muri thin at the top and distinctly thicker towards the base; usually not or only slightly 
interrupted at the poles, rarely distinctly interrupted. Lumina irregular in shape, at the poles large and small lumina intermixed, slightly decreasing towards the equatorial plane and more distinctly towards the colpi. Outlines: Polar view - triangular; sides slightly convex; angles obtuse. Equatorial view - elliptic; long sides slightly concave or straight to slightly convex (sunken poles not always distinct); short sides convex. Measurements: P $11-15 \mu ; \mathrm{E} 17-24 \mu ; \mathrm{P} / \mathrm{E}$ ratio $0.58-0.72$. Exine ca. $1 \mu$ thick or slightly thinner. Lumina up to $4 \mu$ wide at the poles; ca. $1 \mu$ in the equatorial plane.

Species: D. thollonii

\section{Comment}

The $D$. thollonii type resembles the $D$. madagascariense type very closely. Most features are similar in both types, e.g. the short, distinct colpus which is slightly broadened in the equatorial plane and muri distinctly thicker towards the base. The differences with the $D$. madagascariense types are: (1) sexine about as thick as nexine; (2) muri not, or only slightly interrupted; and (3) size of the $\mathrm{E}$ distinctly larger than most of the pollen grains in the $D$. madagascariense type (some specimens excepted). The type cannot be compared with any other pollen type.

\section{Dichapetalum madagascariense type (Plate XIV, 7-16; Plate XV, 1-9)}

Pollen class: 3-Colporate, sometimes a small proportion of 4-colporate pollen grains present, rarely inaperturate. $P / E$ ratio: Usually oblate, rarely suboblate. Apertures: Ectoapertures - colpi, usually short, sometimes rather long, narrow, often slightly broadened at the equatorial plane, not sunken; ends acute; margins distinct or indistinct; no costae. Endoapertures - indistinct, if present usually small, circular pori; no costae.

Exine: Exine thin. Sexine always thinner than nexine, often distinctly thinner; because of this feature columellae and capita are indistinct, only visible as very low processes on the nexine, capita not circular in outline. Ornamentation: As the sexine is thinner than the nexine the ornamentation is often indistinct. Pollen grains faintly reticulate. Reticulum coarse to fine (microreticulate) at the poles. Muri thin at the top and often thicker towards the base; distinctly interrupted at the poles. Lumina irregular and distinctly decreasing towards the colpi and the equatorial plane.

Outlines: Polar view - triangular; sides convex, rarely nearly straight; angles obtuse to subacute. Equatorial view - elliptic; long sides always concave (sunken poles); short sides obtuse if the mesocolpium is seen in optical section and slightly acute if one colpus is seen in optical section.

Measurements: $\mathrm{P} 6-12 \mu ; \mathrm{E} 10-19.5 \mu ; \mathrm{P} / \mathrm{E}$ ratio $0.50-0.78$, usually in the range of $0.55-0.70$. Exine usually less than $1 \mu$ thick. Muri so interrupted at the poles that no measurements have been made of the lumina; in the equatorial plane smaller than $1 \mu$. 
Species: $D$. chalotii, D. gabonense, D. humbertii, D. madagascariense var. madagascariense, $D$. madagascariense var. beniense, $D$. multiflorum, $D$. obanense

\section{Comment}

The $D$. madagascariense type is a clear, homogeneous entity and although several characteristics may vary considerably they do not obscure the close resemblance of all species. The characteristic sexine/nexine ratio which is less than 1 together with the special muri makes the type readily distinguishable.

The variable characters are: (1) colpi vary from short to rather long; (2) the thickness of the muri varies from very thin ( $D$. madagascariense) to rather thick (D. gabonense); (3) the apocolpium may be sunken or not sunken at all; and (4) in polar view the sides vary from distinctly convex to nearly straight.

The pollen grains of the species $D$. madagascariense are easily characterized by a number of features, viz. (1) colpi short and rather indistinct; (2) sexine distinctly thinner than nexine, often nearly lacking; (3) sides distinctly convex in polar view; (4) angles not distinctly subacute. The species occurs in Madagascar, East Africa, Central Africa and a part of West Africa and some specimens have pollen grains which show a remarkable geographical variation. Most specimens show small pollen grains with a sexine almost reduced to nothing (Madagascar), or a sexine which is only slightly thicker than the nexine (East Africa). One specimen collected in the Central African Republic is slightly larger than normal and another one found in the Eastern province of Zaire is distinctly larger and also has a rather distinct sexine. All these specimens resemble each other very closely in other characteristics; they differ only in their size and the thickness of the sexine. The explanation of this remarkable variation in pollen size is unknown.

The taxon $D$. multiflorum was taken into synonymy with $D$. madagascariense by Descoings (1961) but the pollen grains of these species are slightly different. The pollen grains of $D$. multiflorum show the following differential characteristics: (1) colpi rather long and distinct; (2) sexine thinner than nexine, but still distinctly present; and (3) in polar view sides only slightly convex and the angles distinctly subacute.

\section{Dichapetalum timoriense type (Plate XV, 10-15; Plate XIX, 3)}

Pollen class: Inaperturate, i.e. without ectoapertures; endoapertures may be present.

$P / E$ ratio: Suboblate or oblate.

Apertures: Ectoapertures - absent. Endoapertures - present or absent; if present, pori, indistinct, rather small or large, circular in outline; most easily recognizable in polar view as a thinning in the angles. 
Exine: Thin. Sexine about as thick as nexine. Columellae short and indistinct; capita small, circular in outline.

Ornamentation: The ornamentation varies from a tectum perforatum to microreticulate or finely reticulate. Muri relatively thick, sometimes about as thick as the lumina width, often thicker. Lumina irregular in shape to circular, not decreasing towards the angles or equatorial plane.

Outlines: Polar view - usually triangular, sometimes tending towards hexagonal; sides straight to slightly convex, angles obtuse. In hexagonal pollen grains long sides alternating with short. Equatorial view - elliptic; long sides concave (sunken poles); short sides convex.

Measurements: $\mathrm{P} 8-13 \mu ; \mathrm{E} 13-19 \mu ; \mathrm{P} / \mathrm{E}$ ratio $0.55-0.83$, usually in the range of $0.65-0.75$. Exine ca. $1 \mu$ thick. Lumina and perforations varying from narrower than $0.5 \mu$ to ca. $1 \mu$ wide.

Key to the groups

1.a. Pollen grains finely reticulate or microreticulate $\ldots \ldots \ldots \ldots 2$

b. Pollen grains tectate $\ldots \ldots \ldots \ldots \ldots \ldots \ldots \ldots \ldots$

2.a. Endoaperture present $\ldots \ldots \ldots \ldots \ldots$. . . Luzoniense group

b. Endoaperture absent . . . . . . . . . . . . Malaccense group

3.a. Endoaperture present . . . . . . . . . . . Sumbawense group

b. Endoaperture absent ............... Timoriense group

\section{Species: D. timoriense}

\section{Comment}

The $D$. timoriense type is characterized by a set of distinct, constant features, such as: (1) the absence of ectoapertures (pollen grains inaperturate); (2) obtuse angles of the polar view outline; (3) sunken apocolpia. On the other hand, some features vary considerably, in particular: (1) ornamentation varying from finely reticulate (microreticulate) to tectate; (2) endoaperture distinct (Luzonense group) to completely absent (Timoriense group). The variability of the angle width in polar view is less important. In some groups the width of the angles is distinctly less than the length of the sides (Luzonense group) but in others they are the same forming a more or less hexagonal outline (Timoriense group).

'The presence of endoapertures is important for the description of the outlines, since when endoapertures are absent, it is theoretically impossible to distinguish a polar axis or an equatorial diameter. But because of the sequence of morphological features within the Dichapetalaceae as a whole and within the $D$. timoriense type in particular, it is obvious that in the Timoriense group, where the endoapertures are absent, the shortest axis of the elliptical outline must represent the polar axis, whereas the longest axis has to be considered the equatorial diameter. Because of these considerations it seems best to maintain the conventional terminology of Polar axis and Equatorial diameter even in groups without apertures.

The four groups of the $D$. timoriense type have been separated with 
regard to variation in ornamentation and occurrence of endoapertures. Most specimens have pollen grains which can readily be placed in one of the groups, but some show intermediates and these are more difficult to interpret.

Morphologically the $D$. timoriense type resembles the $D$. papuanum type very closely, but the latter differs in the presence of ectoapertures.

\section{Dichapetalum zenkeri type (Plate XVI, 1-9; Plate XIX, 5)}

Pollen class: Inaperturate or more often 3-colporate.

$P / E$ ratio: Usually oblate, sometimes suboblate.

Apertures: Ectoapertures - sometimes absent; if present, colpi indistinct, usually short, narrow; not sunken; ends acute; margins indistinct. Endoapertures - pori, indistinct to rather distinct, circular; no costae.

Exine: Exine thin. Sexine about as thick as nexine or slightly thinner. Columellae short and indistinct; capita indistinct or distinct, more or less circular in outline.

Ornamentation: Reticulate. Reticulum coarse, sometimes rather coarse, rarely fine (microreticulate). Muri thin; either interrupted at poles or not interrupted. Lumina irregular in shape; usually decreasing towards the colpi and the equatorial plane.

Outlines: Polar view - triangular; sides convex; angles obtuse to slightly subacute. Equatorial view - elliptic; long sides convex (poles not sunken); short sides convex.

Measurements: $\mathrm{P} 7-11 \mu ; \mathrm{E} 11-16 \mu ; \mathrm{P} / \mathrm{E}$ ratio $0.63-0.78$, usually in the range of $0.65-0.74$. Exine ca. $1 \mu$ thick or thinner. Lumina varying from $1 \mu$ to $3 \mu$.

Species: D. zenkeri (p.p.), D. sankuruense

Note: Although $D$. sankuruense has been reduced to taxonomic synonymy into $D$. zenkeri, the latter sometimes show pollen grains of the $D$. heudelotii type and has been considered separately in the present investigation.

\section{Comment}

In many characteristics the $D$. zenkeri type resembles the $D$. angolense type, in particular the colpus, which may be either very short with indistinct margins or absent, is very similar. In addition, the outline of the grain which is elliptic without sunken poles in equatorial view and distinctly convex in polar view. Besides the features of the colpus, the outline of the pollen grains in polar view as well as in equatorial view varies little and resembles the $D$. angolense type. In equatorial view the outline is always elliptic and the larger sides never show the slightest tendency to be sunken at the poles. The sides in polar view are always distinctly convex and especially this character keeps the type separate from the distinct triangular $I$ ). angolense type. The most variable character is in the reticulum which is usually coarse and unlike that of the $D$. angolense type, but sometimes it is only rather coarse or even fine. Normally the muri are not interrupted, but they are 
sometimes slightly interrupted and rarely distinctly interrupted (e.g. specimen Talbot 1631 from Nigeria). Another varying character is the sexine/nexine ratio. In most species the sexine is slightly thinner than the nexine giving a rather indistinct reticulum, but in other species the sexine/nexine ratio is ca. 1 and the reticulum is distinctly visible.

Some specimens which have been named $D$. keniense have pollen grains which closely resemble the $D$. heudelotii type. According to modern taxonomists, however, $D$. keniense is synonymous with $D$. zenkeri, but the typical $D$. zenkeri type shows pollen grains which are certainly different from those in the $D$. heudelotii type. In some characteristics they might be better compared with the $D$. madagascariense type (viz. indistinct colpi, shape in polar view and slightly thinner sexine than nexine). The muri of the reticulum are, however, thin and never thicker towards the base. So far no intermediate forms have been observed between the specimens with the $D$. heudelotii type and those with the $D$. zenkeri type.

One specimen exists, however, which is intermediate between the $D$. angolense type and D. zenkeri type. 'The specimen Mildbread 3913 (HBG) from Cameroun $(=D$. molundense) shows more resemblance to the former type in its fine reticulum which does not decrease towards the colpi and its slightly sunken poles, than to the latter type.

Differentiation of the $D$. zenkeri specimens:

D. zenkeri type: Reticulum coarse, colpi indistinct; e.v. elliptic, not sunken.

$D$. angolense type: Reticulum fine, colpi indistinct; e.v. elliptic, slightly sunken.

$D$. heudelotii type: Reticulum fine, colpi distinct; e.v. elliptic, slightly sunken.

\section{Tapura amazonica type (Plate XVI, 10-22; Plate XIX, 6)}

Pollen class: 3-Colporate, rarely 2-colporate.

$P / E$ ratio: Usually varying from prolate-spheroidal to oblate-spheroidal, rarely suboblate or subprolate.

Apertures: Ectoapertures - colpi, long, relatively broad, distinctly sunken; ends acute to slightly rounded; margins distinct or irregular; no costae; fastigium present, but can be small, sometimes margins of the fastigium connected with each other so forming a bridge over the ectocolpus. Endoaperture - colpi or pori, broadly elongated, lalongate; long sides parallel, outer ends diffuse; no costae.

Exine: Thin. Sexine about as thick as nexine, sometimes slightly thinner or slightly thicker. Columellae short and indistinct; capita small, circular in outline.

Ornamentation: Microreticulate or tectate, rarely finely reticulate. Muri thin, not interrupted. Lumina irregular in shape, usually of the same width all over the grain, sometimes slightly larger at the poles (African species). Tectate grains have a tectum with numerous perforations.

Outlines: Polar view - triangular; sides either distinctly convex to slightly 
convex (in the American species) or slightly convex to nearly straight (in the African species); angles obtuse to acute with gaping colpi situated in the angles. Equatorial view - elliptic; longitudinal sides obtusely acuminate because of the fastigia.

Measurements: P $11-20 \mu ; \mathrm{E} 11-23 \mu ; \mathrm{P} / \mathrm{E}$ ratio $0.81-1.20$. Exine usually ca. $1 \mu$, sometimes up to $1.5 \mu$. Lumina width usually smaller than $0.5 \mu$, sometimes up to $1 \mu$. Colpus breadth up to $3 \mu$.

Species: Africana group: T. africana, T fischeri, T. le-testui, T. neglecta Amazonica group: T. acreana, T. amazonica, T. capitulifera, T. cubensis, $T$. guianensis, $T$. juruana, T. lanceolata, T. latifolia, T. peruviana

Key to the pollen groups

1.a. Sides usually distinctly convex in polar view ...... Amazonica group

b. Sides usually slightly convex to straight in polar view . . . . . . . . . . . . . . . Africana group

\section{Comment}

The Tapura amazonica type has many features in common with the Dichapetalum bangii type. The most striking one is the $\mathrm{P} / \mathrm{E}$ ratio, but the outline in equatorial view is also similar. Both types show pollen grains which are more or less spheroidal in shape and circular or slightly elliptic in equatorial outline. Other corresponding characters are: (1) long colpi; (2) presence of fastigia which are, however, more distinct in the Tapura amazonica type; and (3) triangular outline in polar view. The most important differentiating feature is the endoaperture which is relatively narrow and small in the Dichapetalum bangii type. Some other features show a tendency to differ, but they are not constant; viz. (1) the ornamentation of the pollen grains in the Tapura amazonica type is usually tectate with many perforations and the pollen grains are microreticulate in only a few specimens, while the pollen grains of the $D$. bangii type are usually microreticulate; (2) in most Tapura species the pollen grains show very long colpi, i.e. with a small apocolpium; (3) the breadth of the colpi is relatively narrow in the Tapura amazonica type, but not as narrow as in the Dichapetalum bangii type. Some species of Tapura in Africa (e.g. T. fischeri) as well as in America (e.g. T. cubensis) show a $\mathrm{P} / \mathrm{E}$ ratio which is distinctly prolate-spheroidal to subprolate. By this features these species are easily distinguished from those of the Dichapetalum bangii type, where the pollen grains never have such a large $\mathrm{P} / \mathrm{E}$ ratio.

Differences between the Tapura amazonica type and the Dichapetalum bangii type may be difficult to trace, but they are certainly present.

Differences between the pollen grains of the American species of the Tapura amazonica type and those of the African ones are, however, few and indistinct. There is a tendency for the outline in polar view of the pollen grains of the American species to be less triangular than those of the African ones. Usually the American species show pollen grains with slightly to distinctly convex sides, whereas the pollen grains of the African species 
show slightly convex to nearly straight sides. Exceptions exist however in America as well as in Africa.

Because of the continuous variation between the pollen grains, it seems best to keep most of the Tapura species in one variable type.

\section{Tapura bouquetiana type (Plate XVII, 1-7; Plate XX, 5)}

Pollen class: 3-Colporate.

$P / E$ ratio: More or less spheroidal, sometimes slightly oblate or prolatespheroidal.

Apertures: Ectoapertures - colpi, rather long, very narrow, slit-like, not sunken; ends acute; margins more or less distinct; no costae; distinct fastigium. Endoapertures - pori, slightly lalongate-rectangular or quadrangular in shape; distinct margins, but the lateral ends diffuse; faint costae present. Because of the fastigium the apertures protuberant in polar and equatorial view.

Exine: Exine thick. Sexine distinctly thicker than nexine. Columellae varying in length; distinct at the apocolpium, long and slender; in the mesocolpium, especially between the fastigia in the equatorial plane, the columellae are short and indistinct; capita small and circular in outline. Ornamentation: Microreticulate with a tendency to rugulate, or tectate. Tectum with numerous perforations. Muri thin, simplicolumellate. Lumina irregular in shape.

Outlines: Polar view - triangular; sides straight to slightly concave; angles obtuse. Equatorial view - rectangular or quadrangular; sides slightly convex, the lateral sides bulging because of the fastigia; angles obtuse.

Measurements: P 23-25 ; E 22-25 $;$ P/E ratio $0.96-1.03$. Exine up to $2.5 \mu$ thick. Lumina and perforations smaller than $0.5 \mu$.

Species: $T$. bouquetiana

\section{Comment}

The T. bouquetiana type is strikingly different from all other Tapura types. It shows a large number of features not present in any other type, e.g. large pollen grains, thick exine, distinct triangular outline in polar view, costae along endoaperture, tectum, etc. It is a remarkable type and very different from the others with the exception of the T. ivorensis type, which is transitional between the $T$. bouquetiana type and the $T$. amazonica type.

\section{Tapura coriacea type (Plate XVII, 8-11)}

Pollen class: 3-Colporate.

$P / E$ ratio: Usually oblate spheroidal, sometimes spheroidal. Apertures: Ectoapertures - colpi, long, very narrow, slightly sunken; ends acute; margins irregular; no costae; fastigium small, but distinct. Endoapertures - colpi, indistinct, very narrow; outer ends diffuse; no costae. Exine: Thin. Sexine about as thick as nexine, or slightly thicker. Columellae 
short and slender; capita small, more or less circular in outline.

Ornamentation: Microreticulate. Muri thin, usually simplicolumellate, sometimes duplicolumellate. Lumina irregular, not decreasing towards the colpi.

Outlines: Polar view - circular or slightly triangular; sides distinctly convex; angles obtuse. Equatorial view - elliptic with obtuse sides or circular. Measurements: P $16-17 \mu ;$ E $16-19.5 \mu ; \mathrm{P} / \mathrm{E}$ ratio $0.88-1.01$. Exine ca. $1 \mu$ thick or slightly thicker. Lumina usually about $0.5 \mu$ wide.

Species: $T$. coriacea

\section{Comment}

The $T$. coriacea type differs in several characteristics from the $T$. amazonica type. Especially the features of the endoaperture are different (small, narrow and indistinct), but also the outline in polar view differs (circular or nearly so). Moreover, the overall size is greater. The pollen type has less in common with the $T$. juliani type.

\section{Tapura ivorensis type (Plate XVII, 12-16; Plate XVIII, 1, 2)}

Pollen class: 3-Colporate.

$P / E$ ratio: Suboblate to rarely oblate.

Apertures: Ectoapertures - colpi, long, narrow, slightly broader at the equatorial plane, not sunken; ends acute; margins distinct; no costae; distinct fastigium. Endoapertures - pori or colpi, lalongate, large, rectangular in outline; faint costae along the long sides; outer ends diffuse. Exine: Thin. Sexine about as thick as nexine or slightly thicker. Columellae short and indistinct; capita small, circular in outline.

Ornamentation: Reticulate or microreticulate. Reticulum fine to coarse. Muri thin, probably simplicolumellate. Lumina large, often intermixed with very small lumina; distinctly decreasing towards the colpi and mesocolpia. Outlines: Polar view - triangular; sides straight to slightly convex; angles gaping. Equatorial view - elliptic; sides convex.

Measurements: P 14-16.5 $;$ E $15-19 \mu ; \mathrm{P} / \mathrm{E}$ ratio $0.84-0.91$. Exine ca. $1 \mu$ thick. Lumina at the poles up to $2.5 \mu$, usually ca. $1.5 \mu$.

Species: T. ivorensis

\section{Comment}

The $T$. ivorensis type has several features in common with the $T$. amazonica type. The most important difference is found in the features of the endoaperture which is rectangular and bordered by faint costae. Also the ornamentation differs in lumina of the reticulum which are wider than those in the T. amazonica type and distinctly decreasing towards the colpi. Moreover, the pollen grains have a polar view outline which is distinctly triangular. This latter feature is present in most African species of the $T$. amazonica type, but occurs less frequently in the American ones. The pollen grains of the $T$. ivorensis type are intermediate between the $T$. amazonica type and the $T$. bouquetiana type. 
28. Tapura juliani type (Plate XVIII, 3-6, 10, 11)

Pollen class: 3-Colporate.

$P / E$ ratio: Usually slightly prolate-spheroidal, sometimes spheroidal to oblate-spheroidal.

Apertures: Ectoapertures - colpi, long, narrow, slightly to distinctly sunken; ends acute; margins distinct; no costae; distinct fastigium present. Endoapertures - colpi, distinct, rather broad, lalongate; long sides with distinct margins; outer ends diffuse; faint costae present.

Exine: Exine rather thick. Sexine about as thick as nexine or slightly thicker. Columellae short and indistinct; capita small and more or less circular in outline.

Ornamentation: Microreticulate, tending towards a tectum perforatum. Muri relatively thick; probably simplicolumellate. Lumina irregular in shape, not decreasing towards the colpi.

Outlines: Polar view - triangular; sides slightly convex; angles more or less acute. Equatorial view - slightly elliptic to rectangular; all sides convex; angles obtuse.

Measurements: P 17.5-20.5 ; E 17-21 $\mu ; \mathrm{P} / \mathrm{E}$ ratio $0.92-1.10$. Exine ca. $1.5 \mu$ thick. Lumina (perforations) always smaller than $1 \mu$, usually ca. $0.5 \mu$.

Species: T. juliani

\section{Comment}

The $T$. juliani type shows a close resemblance to the T. amazonicum type, especially to those species which are prolate-spheroidal. It differs, however, in the presence of faint costae along the endoapertures and a greater overall size. It appears to be intermediate between the $T$. amazonica type and the Stephanopodium engleri type.

\section{Stephanopodium engleri type (Plate XVIII, 7-9, 12-14)}

Pollen class: 3-Colporate.

$P / E$ ratio: Usually prolate-spheroidal; sometimes spheroidal, rarely oblatespheroidal.

Apertures: Ectoapertures - colpi, long or rather long, very narrow, slit-like, slightly sunken; ends acute; margins distinct; no costae; distinct fastigium. Endoapertures - pori or colpi, large, broadly elongated, lalongate, rather indistinct, parallel long sides, diffuse outer ends; no costae.

Exine: Exine rather thick. Sexine thicker than nexine. Columellae long and slender; capita indistinct, forming a tectate layer.

Ornamentation: Tectum smooth, sometimes with perforations; which may make an LO pattern distinguishable.

Outlines: Polar view - triangular to nearly circular; sides distinctly convex; 
angles obtuse, slightly open. Equatorial view - elliptic or circular to slightly quadrangular (rectangular); sides convex at the poles, bulging at the equator because of the protuberant fastigia; angles obtuse.

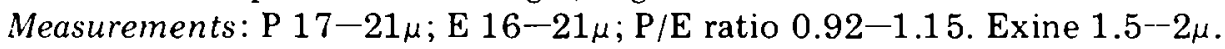
Species: $S$. blanchetianum, $S$. engleri

\section{Comment}

The Stephanopodium engleri type closely resembles the American Tapura types, particularly the $T$. juliani type, but it is distinguished by such characters as the tectate sexine 2 and the rather thin exine.

\section{EVOLUTIONARY TRENDS}

\section{Description of the evolutionary trends}

In previous publications of the author (Punt, 1967, 1968, 1970; Smit and Punt, 1969) one of the main subjects of discussion was the existence of evolutionary trends in the material studied. Other palynologists (e.g. VishnuMittre, 1964; Nair, 1966; Van Campo, 1966; Muller, 1970a; Reitsma 1970b; and Walker, 1971) have also discussed the possibility of such evolutionary trends providing a clue to phyletic classification. All authors know and stress, that phylogeny and evolution are concerned with time and space (geography), and basic information of this type is to a large extent obtained from fossils since the earliest mesophytic deposits. 'The best paper on this subject, based on an exhaustive list of specialized literature, is by Muller (1970a). In a previous paper, Muller and some other palynologists (Germeraad et al. 1968) were able to give an excellent demonstration of evolution. The pollen grains of Florschuetzia are already present in the lower deposits of the Tertiary of Borneo and they gradually develop into the pollen grains of the present taxon Sonneratia. Such examples, however, are exceptions.

Mlost authors are limited to working with the pollen grains of recent taxa, comparing the grains of different taxa and noting morphological differences. $\Lambda$ dding this to the scanty knowledge of fossil pollen grains they try to interpret the botanical series in terms of lines of evolution (Van Campo, 1966; Reitsma, 1970b).

The present paper has also been concerned with recent plants only. Lnfortunately, no fossil grains of the Dichapetalaceae have been available, and lines of evolution have had to be established by analogy with other lines of development (Punt, 1967, 1968, 1971; Punt and Leenhouts, 1967; Smit and Punt, 1969). In all these papers the term "evolutionary trend" was used to stress the direction in the morphological series, for by this term it was suggested that evolution might have developed in a specific direction. Of course, the range of features in pollen grains must in principle be considered a morphological series, but it seems logical to take the argument a step further while realizing that every suggested evolutionary line 
might be rejected in the future when geological data is forthcoming. On the other hand, with our present knowledge of the fossil record, and of evolutionary processes in pollen grains, it is often possible to suggest certain lines of evolution, several of which have been accepted by almost every pollenmorphologist thinking about pollen and evolution. On the other hand, there are several morphological series known, which are not accepted by all authors as lines of evolution, and very often such lines are not confirmed by the fossil record.

All such lines of evolution, whether confirmed by fossils, or unconfirmed but still highly probable, are called "evolutionary trends". If the direction of the development of the features is not certain it is better to speak of morphological series. The definition given by Reitsma (1970b) "The succession or probable succession of a pollen character from primitive to advanced is an evolutionary trend"', also indicates the differences between evolutionary trend and botanical series.

Evolutionary trends as described by different authors can be divided into four categories:

Category $A$. Evolutionary trends mentioned and accepted by most authors. To this category belong the following trends:

I. Colpus $\rightarrow$ porus (Vishnu-Mittre, 1964; Van Campo, 1966; Nair, 1966; Punt, 1967; Muller, 1970a; Reitsma, 1970b; Thanikaimoni, 1971; Walker, 1971).

II. Increasing number of apertures (Vishnu-Mittre, 1964; Van Campo, 1966; Punt, 1967; Muller, 1970; Reitsma, 1970b).

III. Increase in size (Van Campo, 1966; Punt, 1968; Miuller, 1970a; Reitsma, 1970b).

IV. Increase in ornamentation complexity (Vishnu-Mittre, 1964; Nair, 1966; Van Campo, 1966; Punt and Leenhouts, 1967; Muller, 1970a; Reitsma, 1970b).

Category $B$. Trends which seem probable and are accepted by several authors, but are not mentioned by all. Nobody, however, has disagreed with these evolutionary trends. The following trends have been noticed:

V. Colpi with a single endoaperture $\rightarrow$ colpi di-endoaperturate (diorate) (Vishnu-Mittre, 1964; Punt, 1967).

VI. Colpate $\rightarrow$ colporate (Vishnu-Mittre, 1964; Van Campo, 1966; Muller, 1970a).

Several other trends not mentioned by all authors, but which may be accepted, belong to the complex of features already included in the general principle that simple is more primitive than complex (Category A IV). This general principle can be proved by fossil data (Muller, 1970a). Some of them have been published incidentally by different authors and several more will be published under the evolutionary trends of the Dichapetalaceae (see below).

Category $C$. This category comprises controversial trends. The trends are mentioned by two or more authors, but the direction of the lines is reversed. Examples are: 
VII. Exine thick $\rightarrow$ exine thin (Nair, 1966).

Exine thin $\rightarrow$ exine thick (Punt, 1971).

VIII. Pollen grains "breviaxe" $\rightarrow$ pollen grains "longiaxe" (Van Campo, 1966).

Pollen grains suberect (prolate) $\rightarrow$ pollen grains transverse (oblate)

(Punt, 1967; Reitsma, 1970b).

Category $D$. If the evolutionary trends established by Punt (1967, 1971; Smit and Punt, 1969) are compared, it is clear that most of them are generally accepted trends. Besides these well-known trends, however, every list contains one or two special trends occurring only in the taxa under consideration. In Phyllanthus (Punt, 1967), the colpus margins showed a specialization not met with anywhere else; in Caltha (Smit and Punt, 1969), the endocracks in the nexine appeared to be a new trend, and in the Marcgraviaceae (Punt, 1971) the special part in the middle of the endoaperture was an exclusive feature to that family. The present author would like to put these special evolutionary trends in a separate Category D.

The establishment of evolutionary trends without palaeobotanical data can only be accepted as a working hypothesis; all the palynologists cited above are aware and have stated in their papers, that an evolutionary trend never can give proof of the real pattern of evolution.

In the Dichapetalaceae a large number of trends are suggested, belonging to all four categories. The following evolutionary trends, classified according to the general description of the pollen grains, have been postulated.

\section{Apertures}

Ectoapertures

1. Ectocolpi long $\stackrel{\text { a }}{\rightarrow}$ colpi short $\stackrel{b}{\rightarrow}$ colpi absent.

Endoapertures

2. Ectocolpi without margo $\rightarrow$ colpi with margo.

3. Endocolpi $\stackrel{a}{\rightarrow}$ lalongate porus $\stackrel{b}{\rightarrow}$ porus $\stackrel{c}{\rightarrow}$ porus indistinct to absent.

4. Costae absent $\rightarrow$ costae present.

Exine

Ornamentation

\section{Outlines}

Polar view

Equatorial view

12. Sides distinctly convex $\stackrel{a}{\rightarrow}$ slightly convex $\stackrel{b}{\rightarrow}$ straight $\stackrel{c}{\rightarrow}$ sides concave.

13. $\mathrm{P} / \mathrm{E}$ ratio \pm spheroidal $\rightarrow$ suboblate or oblate. 
14. $\mathrm{P} / \mathrm{E}$ ratio \pm spheroidal $\rightarrow$ prolate-spheroidal or subprolate.

15. Long sides convex $\rightarrow$ sides slightly concave (apocolpium sunken).

Measurements $\quad 16$. Small size $\rightarrow$ larger size.

17. Lumina small $\rightarrow$ lumina larger.

In certain cases structures and ornamentation develop from complex to simple. This is the phenomenon of reduction, e.g. reduced ornamentation (trend 10) must be considered more advanced than complex structures.

\section{Discussion of the evolutionary trends}

Trend 1. The shortening of the ectocolpus is a trend accepted by all authors (Category A I) and it is clearly demonstrated in the Dichapetalaceae. Distinct long colpi are present in the $D$. bangii type, the Stephanopodium type and all Tapura types; in addition the colpi of the $D$. bangii type and Tapura amazonica type are narrow, but not very narrow. In Dichapetalum, and also to some extent in Tapura, there is a tendency for the breadth of the colpi to decrease to very narrow (slit-like).

In Dichapetalum all pollen types show a short colpus except the $D$. bangii type and $D$. chlorinum type. Consequently, the $D$. bangii type can be accepted as the most primitive pollen type in Dichapetalum. There is, however, one exception. The $D$. chlorinum type with one endemic species in Madagascar shows a colpus which is long, running far into the apocolpium, but this type is so advanced in its other features, that one has to accept that in this single species the evolutionary trend was from long to very long.

The shortening of the colpi goes so far that some types fail to show any trace of an ectoaperture at all and these types (e.g. D. mundense type, $D$. leucosia type, etc.) are inaperturate, but they may show endoapertures. Some specimens in $D$. timoriense lack both ecto- and endoaperture.

Trend 2. The presence of a margo is a trend already mentioned by Reitsma (1970b) and can be placed best in Category A IV (from simple to complex). It is not much developed in the Dichapetalaceae. In the Dichapetalum gilletii type only one group (Reticulatum group) shows a distinct margo while the other groups of the same type lack this feature completely.

Trend 3. Endoapertures may be considered totally independent of the ectoapertures with regard to size and shape. It is accepted, however, that just as in trend 1 for ectoapertures lalongate endoapertures (either colpi or pori) are more primitive than circular endopori (Category A I). This general trend, the differentiation from endocolpus to endoporus, has already been accepted by Punt (1967) and Reitsma (1970b).

In the Dichapetalaceae the genus Dichapetalum usually shows pollen grains with an endoporus. The $D$. bangii type only shows an endocolpus. All 
other Dichapetalum pollen types have either lalongate endopori (D. mombuttense type, $D$. gelonioides type, etc.) or circular pori. In Tapura the endoapertures are usually lalongate pori and only rarely colpi. In the $T$. bouquetiana type and the $T$. ivorense type the endoapertures are rectangular pori. As a rule the endoapertures in the Tapura types are more differentiated and more important for the classification than in the Dichapetalum types.

Trend 4. The presence of costae is like the presence of a margo, a rather rare feature in the Dichapetalaceae. As most authors accept the hypothesis that complex ornamentation is more advanced than simple patterns, it seems logical that pollen grains with costae are more advanced than those without them. This trend was already mentioned by Reitsma (1970b) and is accepted for the Dichapetalaceae as well.

In Dichapetalum, costae occur in one species of the $D$. barbosae type (D. arenarium) and in some groups of the D. gelonioides type. In Tapura, however, three different types ( $T$. bouquetiana, T. ivorense, $T$. juliani) show costae along the margins of the endoapertures.

Trends 5 and 6. Exine features have been shown to be rather important among the evolutionary trends. In the genus Costus (Punt, 1968) and especially in the Marcgraviaceae (Punt, 1971) and Alangiaceae (Reitsma, $1970 \mathrm{~b}$ ), it was clear that the change in sexine/nexine ratio have to be considered significant. This change in sexine/nexine ratio can develop in two opposite directions. In the Marcgraviaceae (Punt, 1971) there was a distinct trend to an increasing nexine while the sexine, on the other hand, hardly altered in thickness. In the Alangiaceae (Reitsma, 1970b) the trend was twofold. Some advanced types showed a sexine much thicker than the nexine and the ornamentation was very complex, but other types, showing just the opposite, had a nexine distinctly thicker than the sexine.

The sexine/nexine ratio in the Dichapetalaceae can also be divided into two lines. The 5th trend, a sexine thicker than nexine is only weakly represented in Dichapetalum (D. macrocarpum type) and Tapura ( $T$. bouquetiana type) as well as in the Stephanopodium type. Trend 6, on the other hand, is of great importance in Dichapetalum, but not present in Tapura. The trend goes to such an extreme in the $D$. madagascariense type and the $D$. barteri type, where the sexine is so highly reduced that the ornamentation is very faint or may even be absent.

Trend 7. The trend accepted here as running from reticulate to tectate, is not accepted by all authors (Category C). Nair (1966) suggests an opposite trend and some others, although not positive in this matter (e.g. Muller, $1970 \mathrm{~b}$; Thanikaimoni, 1971), tend to believe that reticulate pollen grains are more advanced than tectate ones.

It may be true that this trend changes from group to group depending on the starting feature of the most primitive group in the taxon in question. The most primitive pollen grain in a group may already be tectate, and with a tectate pollen grain as starting point the trend may run from simple tectate to complex reticulate pollen grains. In this respect it is most interesting 
that Walker (1971) in his pollenmorphological treatment of the Annonaceae indicates two diverging trends: (1) tectal perforations medium sized $\rightarrow$ tectal perforations reduced; (2) tectal perforations medium sized $\rightarrow$ tectal perforations enlarged. Much work has to be done to solve this problem.

Most pollen types in the Dichapetalaceae are reticulate and only few types show a tectum. It is remarkable that most of the types with a perforate or closed tectum are found in America (D. pedunculatum type) and Asia (D. gelonioides type, $D$. grandifolium type, $D$. timoriense type), while none of the African Dichapetalum types is tectate. In Tapura on the other hand the trend is present in both the African and the American types.

Trend 8 . Reticulate ormamentation has been accepted as primitive in the Dichapetalaceae, and consequently a pilate pattern, where the reticulum is reduced, is a more advanced feature. The same trend was suggested in the genus Phyllanthus (Punt, 1967) and the trend falls into Category B. It must be pointed out, however, that very little is published on the possibility of reduction of ornamentation being an advanced feature, but in classical taxonomy reduced plants are usually accepted as more advanced than normally developed plants in the same group.

In Dichapetalaceae reduction of ornamentation occurs rather regularly, viz. reduction of colpi, reduction of lumina of the reticulum, reduction of the sexine. The reduction from a reticulate ornamentation to a pilate one is only found in a few types. The most complete reduction is present in the $D$. gilletii type and the $D$. mundense type which are pilate in all parts of the pollen grains. Two types are partly pilate: (1) D. barbosae type is pilate in the equatorial field of the mesocolpia; (2) $D$. mombuttense type is pilate at the apocolpium. Both types also have many other features which might be considered advanced.

Trend 9. The trend from muri which are equally thin above and below to muri which are thicker at the base has previously been reported by Muller (1970b) in the genus Lepisanthes (Sapindaceae) and it may also be considered characteristic of the Dichapetalaceae (Category D).

In Dichapetalum the following types show the trend to a certain extent: $D$. madagascariense type, $D$. thollonii type, $D$. chlorinum type, $D$. long $i$ petalum type, $D$. leucosia type and $D$. mombuttense type.

Trend 10. The reduction of the muri of the reticulum at the apocolpium is an advanced feature which is peculiar to the family (Category D) and has not been reported elsewhere.

In the Dichapetalaceae it is a rather common trend in Dichapetalum where it is a differentiating characteristic for several types such as the $D$. heudelotii type, D. longipetalum type, the Leucosia group of the D. leucosia type, etc.

Trend 11. A very common feature, the decreasing of the lumina of the reticulum towards the colpi, listed here as an advanced characteristic, was also noticed by Muller $(1970 \mathrm{~b})$. It certainly conforms with the general rule that simple ornamentation is more primitive than complex and the trend is placed in Category B. 
Several Dichapetalum types show this feature, e.g. D. heudelotii type, D. leucosia type, etc.

Trend 12. The change of the sides in the outline of the pollen grains in polar view is a distinct trend in the Dichapetalaceae. It is obvious that this trend may not only occur in the Dichapetalaceae. Also pollen grains from other taxa show straight or concave sides (Olacaceae, Rhamnaceae, etc.). On the other hand, insufficient data are available to be sure that in all these taxa the trend will run in the same direction. Therefore it seems best to classify this trend in Category B.

The Dichapetalum types demonstrate the trend best; there are types with distinctly convex sides ( $D$. bangii type, $D$. leucosia type), slightly convex sides (e.g. D. madagascariense, D. heudelotii type), straight sides ( $D$. macrocarpum type) and concave sides ( $D$. barbosae type). In Tapura this trend is present to a small degree, but far less developed in the different types.

Trend 13 and 14 . The trend of the $\mathrm{P} / \mathrm{E}$ ratio is one of those controversial trends for which much more evidence is still needed (Category C). After studying several taxa with "breviaxe" pollen grains Van Campo (1966) came to the conclusion that "breviaxe" pollen might be primitive and "longiaxe" pollen grains advanced. Punt $(1967,1971)$ and Reitsma (1970b) both argue for a trend running in the opposite direction. The problem, however, is complex. In some taxa the trend may run from spheroidal to prolate, while in other taxa it is in the reverse direction from spheroidal to oblate.

In the Dichapetalaceae it may be suggested that in the genus Dichapetalum the pollen grains have evolved according to trend 13 (D. bangii type $\rightarrow$ $D$. angolense type $\rightarrow D$. mombuttense type) and some types in Tapura along a line given in trend 14 (T. amazonica type $\rightarrow T$. juliani type $\rightarrow$ Stephanopodium engleri type).

Trend 15. A special trend occurring in the genus Dichapetalum only and not mentioned by any other author is the feature of the slightly sunken apocolpium (Category D). In the outline of the equatorial view this results in the long sides being slightly concave.

The feature is observed in several types of Dichapetalum, e.g. $D$. heudelotii type, $D$. mombuttense type, etc.

Trend 16. A general trend noticed by many authors is that large pollen grains are more advanced than small ones (Category A). The trend is mentioned by Muller (1970a), Van Campo (1966) and Walker (1971). However, as Walker (1971) stated, the trend can also be from large to small. Of course, this latter trend may occur easy in taxa in which the most primitive representative is already large, which is true for Annonaceae.

In Dichapetalaceae the trend is undoubtedly from small to large. Pollen types with relatively large pollen grains are the $D$. gilletii type, $D$. macrocarpum type, Tapura bouquetiana type, etc.

Trend 17. The trend of increasing lumina size is also mentioned by Walker (1971) and is therefore placed in Category B. The trend is quite marked in the genus Dichapetalum in the D. zenkeri type and D. longi- 
petalum type. As was stated earlier, the trend can also be seen as a derivative line from tectate $\rightarrow$ finely reticulate $\rightarrow$ coarsely reticulate (see trend 7 ).

\section{Interpretation of the evolutionary trends}

If the evolutionary trends described above are taken as a starting point for the Dichapetalaceae, then it is possible to arrange the pollen types into a scheme of pollenmorphological relationships (Fig.1).

Each type has its own differentiating characters and all features are compared with the list of evolutionary trends as given above. Thus every step is visualized as a number corresponding with the numbers as given in this list.

The most primitive types (primitive according to the list of trends) are placed at the base of the scheme and the most advanced ones can be found sideways and at the top. In the scheme the circles represent types with several taxa (species as well as subspecies); small circles with few taxa, large circles with many taxa. A point indicates a type with one taxon only.

In the scheme several pollen types seem pollenmorphologically related to some extent and they are placed in clusters, viz: (1) the Dichapetalum bangii cluster; (2) the $D$. angolense cluster; (3) the $D$. heudelotii cluster; (4) the D. madagascariense cluster; (5) the $D$. gelonioides cluster; (6) the Tapura amazonica cluster. The clusters will be discussed below.

(1) Dichapetalum bangii cluster (Fig.2). This cluster, comprising the Dichapetalum bangii type, $D$. leucosia type, $D$. papuanum type and $D$. timoriense type at the base of the scheme, represents the most interesting part of the clusters. All Dichapetalaceae types, with the exception of the $D$. bangii type, are much alike in their $\mathrm{P} / \mathrm{E}$ ratio and their outlines in equatorial view. The $D$. bangii type, however, differs in a number of characters, and if these are compared with those occurring in the list of evolutionary trends, it is clear that the type must be considered the most primitive in the family. Particularly the outlines of the pollen grains together with the indistinct, colpus-like endoaperture, place the $D$. bangii type at the base of the evolutionary line. In most of its characters it resembles the Tapura amazonica type more than any other type of the genus Dichapetalum. In fact, it can only be differentiated by one rather inconstant character and it is obvious that both types are related. According to their gross morphological features, however, the species in the Dichapetalum bangii type and those of the Tapura amazonica type are undoubtedly different. The lack of differentiation in pollen characters between such different genera can only be explained by assuming that the pollen grains have remained primitive. For some unknown reason the pollen grains in the species of the Dichapetalum bangii type failed to evolve further and they may resemble most closely the ancestral pollen type of all Dichapetalaceae. Consequently, it is the particularly primitive Dichapetalum bangii type which should be compared with pollen types of other families. 


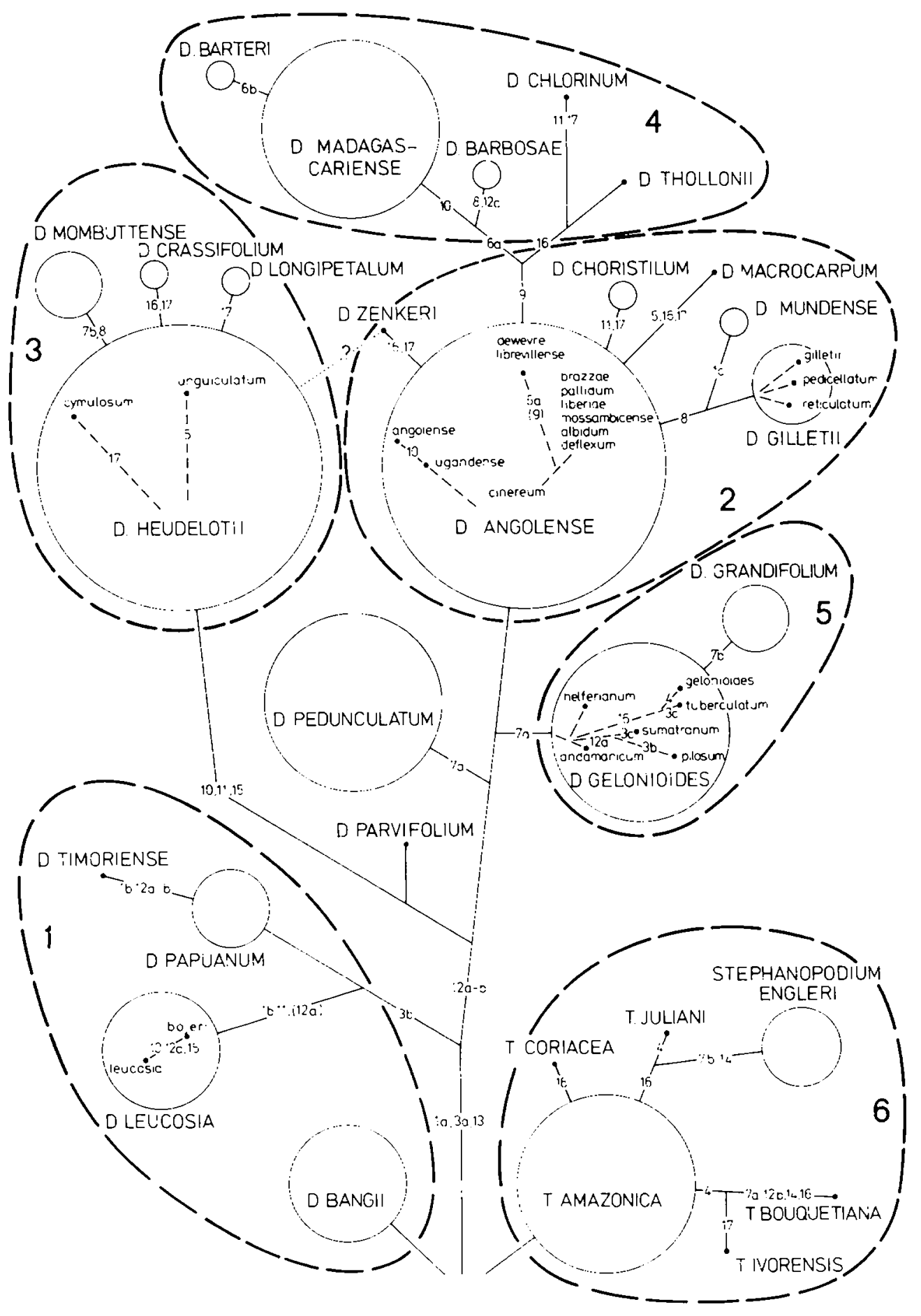


Closely related to the Dichapetalum bangii type and still at the base of the scheme, is the D. leucosia type which occurs in Madagascar, the $D$. papuanum type restricted to the eastern part of Malesia* and the $D$. timoriense type present throughout Malesia, but better represented in the eastern than in the western part (it is absent on Sumatra). It is remarkable that representatives of this group of related types are completely absent on the continent of Africa, where most of the Dichapetalaceae occur.

With regard to the groups in the $D$. timoriense type it is clear that the Luzoniense group is the most primitive. It shows a reticulate ornamentation and has a distinct endoaperture. The Malaccense group is slightly more advanced with regard to the endoapertures (indistinct to absent). The most advanced group is the Timoriense group which is tectate and without endoapertures, whereas the Subawense group is intermediate between the Luzoniense group and the Timoriense group. The $D$. timoriense type as a whole is undoubtedly related to the $D$. papuanum type. The former must, however, be considered more advanced than the latter, as it lacks ectoapertures (trend $1 \mathrm{~b}$ ).

(2) The Dichapetalum angolense cluster (D. angolense type, $D$. choristilum type, $D$. gilletii type, $D$. macrocarpum type, $D$. mundense type, D. zenkeri type).

This group of types encircling the $D$. angolense type shows great diversity and considerable variability in its features. One of the most constant characteristics is the indistinct, short ectoaperture which may even be absent. For this reason the $D$. pedunculatum type as well as the $D$. gelonioides type with distinct margins to their ectoapertures have been treated as earlier off-shoots of the main branch towards the $D$. angolense type although both are certainly related to this latter type. Directly related to the species in the $D$. angolense type are the $D$. gilletii type and the $D$. mundense type. They resemble $D$. pallidum very closely, but differ in the presence of pila. Two other types, the $D$. choristilum type and $D$. macrocarpum type, show a strong resemblance to $D$. liberiae and $D$. mossambicense, differing, however, in ornamentation and size. The $D$. zenkeri type, although placed near the $D$. angolense type, has also some features in common with the $D$. heudelotii type.

(3) The $D$. heudelotii cluster ( $D$. crassifolium type, D. heudelotii type, $D$. longipetalum type, $D$. mombuttense type) shows less variance between its types. A basic set of characteristics clearly indicates their relationship, viz. decreasing lumina towards the colpi, interrupted muri, a subacute outline in polar view, and a sunken apocolpium. The species in the largest type, the

*Malesia: Malaysia, Indonesia, the Philippines and New Guinea.

Fig.1. Scheme of pollenmorphological relationships.

Circles represent types: large circles, types with many taxa; small circles, with few taxa; a point indicates a type with one taxon only. The dotted areas represent clusters of pollen types. 1. Dichapetalum bangii cluster. 2. Dichapetalum angolense cluster. 3. Dichapetalum heudelotii cluster. 4. Dichapetalum madagascariense cluster. 5. Dichapetalum gelonioides cluster. 6. Tapura amazonica cluster. 


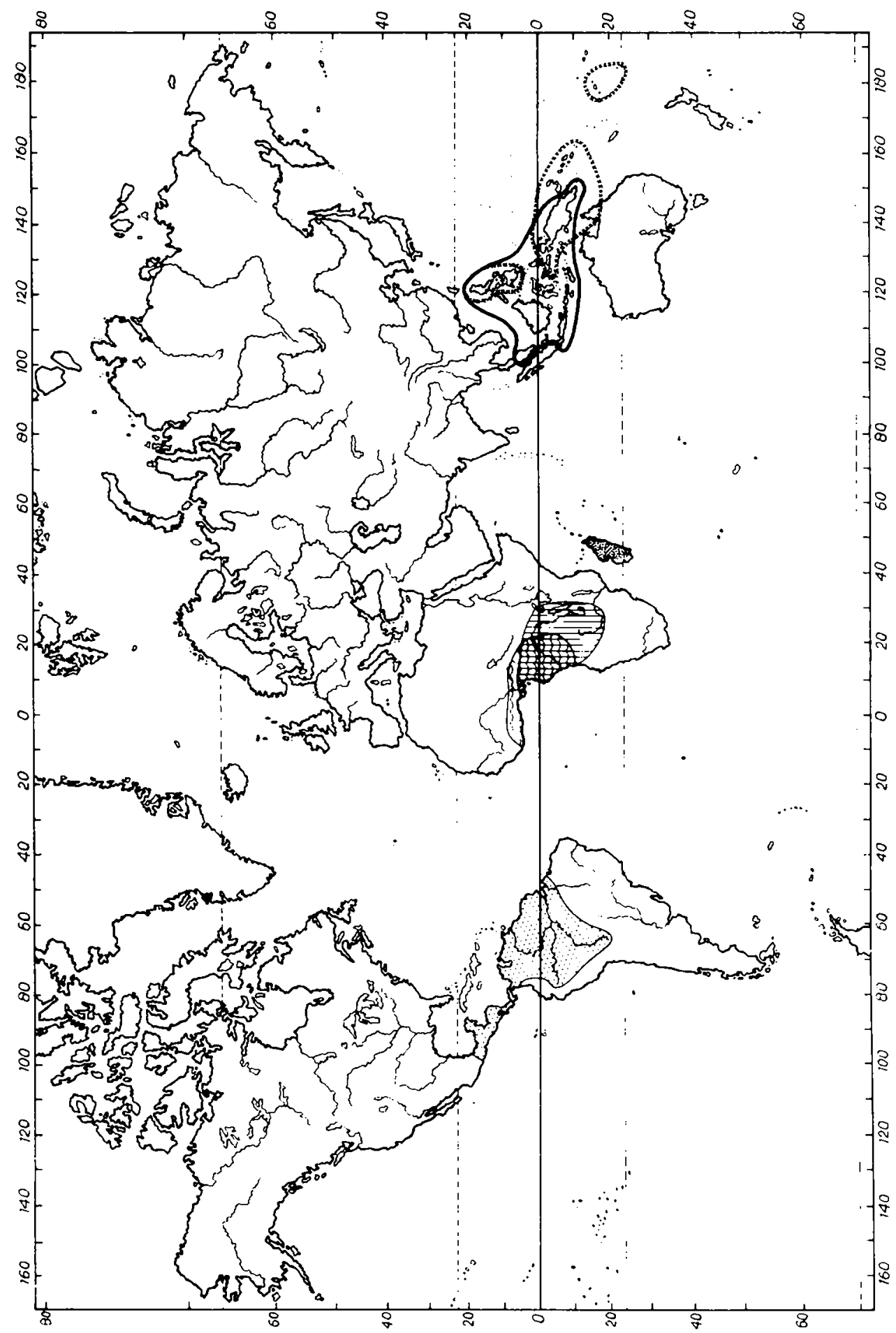


$D$. heudelotii type, also differ less from each other than those in the $D$. angolense type.

(4) The $D$. madagascariense cluster ( $D$. madagascariense type, $D$. barbosae type, D. barteri type) (Fig.3). The madagascariense type and those closely related to it are the most advanced pollen types in the Dichapetalaceae. The feature which connects all types is increasing thickness of the muri of the lumina towards the base. By this character the group of types is also connected with the species $D$. deweurei and $D$. librevillense of the $D$. angolense type.

(5) The $D$. gelonioides cluster. The Asian $D$. gelonioides type and $D$. grandifolium type are closely related and form a distinct group of types. The nearest pollenmorphological relative of the $D$. gelonioides type is the $D$. angolense type which has several characteristics that can be found again in the Andamanicum group, the most primitive group in the $D$. gelonioides type. However, the combination of characters described for the Andamanicum group is not present in any special group of the $D$. angolense type (see p. 55). In Fig.4 the relationship between the groups of the $D$. gelonioides type and the $D$. grandifolium is suggested. The differential characteristic between the $D$. gelonioides type and the $D$. grandifolium type is based on trend $7 \mathrm{~b}$ (tectum perforated to closed tectum).

The $D$. gelonioides type clearly demonstrates that within a relatively small entity pollen can evolve rapidly (see also the $D$. zenkeri type, p. 42; $D$. angolense type, p. 55; and the D. madagascariense type, p. 39).

(6) The Tapura amazonica cluster (T. amazonica type, T. ivorense type, $T$. coriacea type, $T$. juliani type, Stephanopodium engleri type). The wealth of differentiation demonstrated in Dichapetalum is not present in the genus Tapura. The Tapura amazonica type has to be considered the basic type comprising African species as well as American ones. Within Tapura, however, there are few species which are sufficiently distinct from the $T$. amazonica type to form their own pollen type. Of these the $T$. bouquetiana type is the most advanced type. The Stephanopodium engleri type is also related to the T. amazonica type via the $T$. juliani type.

\section{Relationship with other families}

When comparing pollen grains in one family with those of another it would be most unwise to take a single taxon from a family and to compare it with one other taxon from another family. In the Dichapetalaceae it is obvious that the highly advanced pollen grains occurring in the D. madagascariense type are not to be compared with a pollen type from any other

Fig.2. Distribution of the $D$. bangii cluster and of the $D$. parvifolium type and the I). pedunculatum type.

1. Coarse-dotted area: $D$. pedunculatum type. 2. Horizontal waves: $D$. parvifolium type. 3. Vertical lines: $D$. bangii type. 4. Fine-dotted area: $D$. leucosia type. 5 . Area surrounded by closed line: $D$. timoriense type. 6 . Area surrounded by crosses: $D$. papuanum type. 


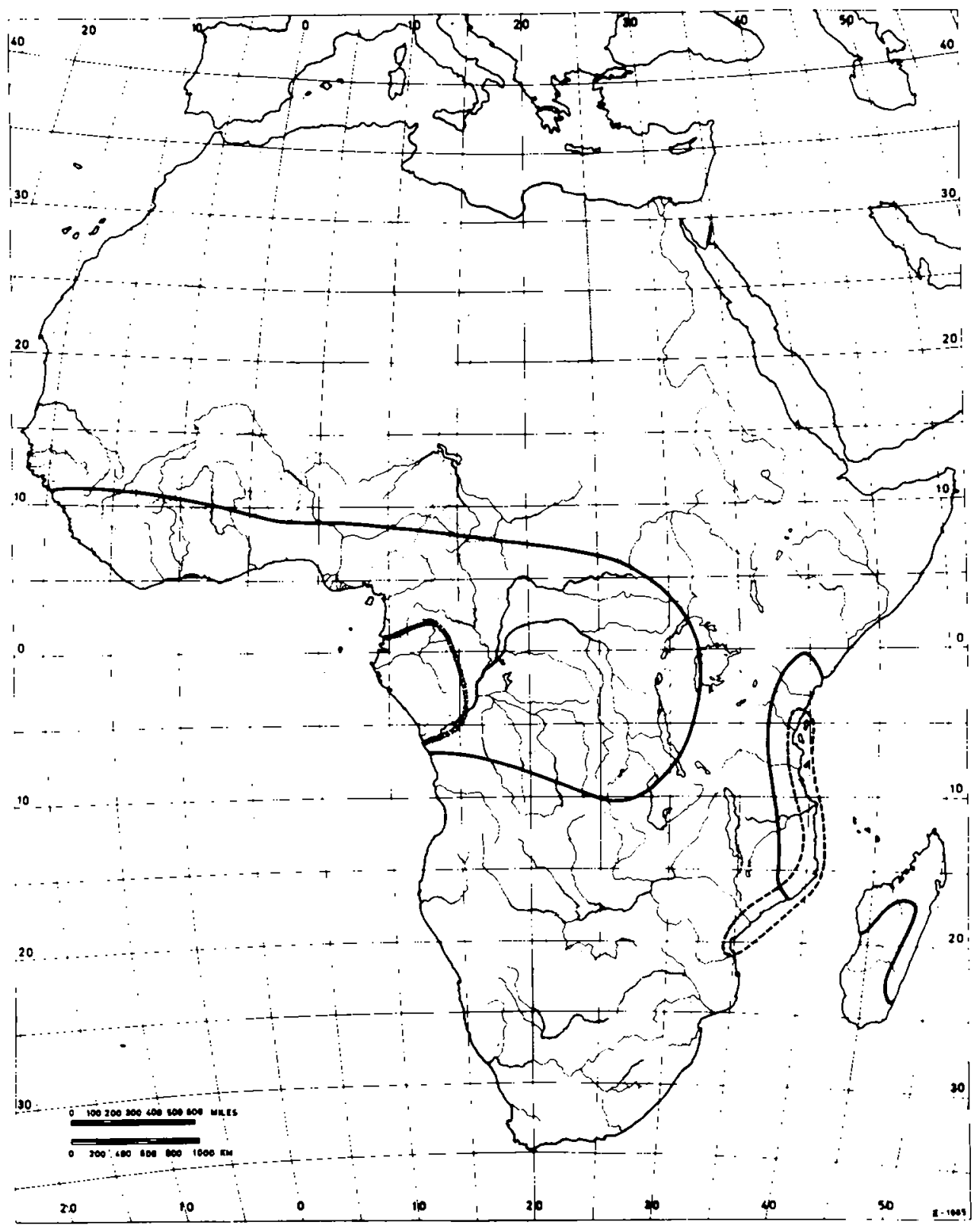

Fig.3. Distribution of some types of the $D$. madagascariense cluster.

1. Area enclosed by line: $D$. madagascariense type. 2 . Area enclosed by crosses:

$D$. thollonii type. 3 . Area enclosed by interrupted line: $D$. barbosae type. 


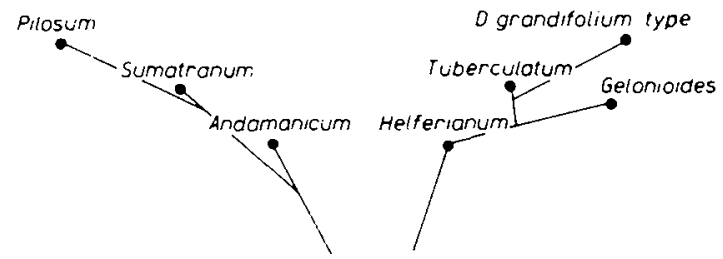

Fig. 4. Relationships between the $D$. gelonioides type and the $D$. grandifolium type.

family. Two conditions must be fulfilled before a pollenmorphologist can draw justified conclusions: (1) the whole family must be known; and (2) evolutionary trends must have been established to give information about primitive and advanced representatives.

In this connection it is interesting to read the comment of Lobreau (1969) on the pollenmorphological relationship of the Dichapetalaceae with other taxa. It has to be noticed, that in Dichapetalum this author compared a relatively advanced pollen grain (Dichapetalum nigrescens of the D. leucosia type) with those of the Pandaceae and the genus Stemonurus in the Icacinaceae. Although there may be a superficial overall resemblance, it is obvious that this can only be the result of convergence in detail, since the pollen grains compared, differ widely in their general morphology.

The comparison, however, of Tapura neglecta pollen grains (Tapura amazonica type), which are certainly primitive, with pollen grains of other taxa makes better sense. Lobreau compares the pollen grains of Tapura with Rhamnaceae and Euphorbiaceae. I do not know the pollen grains of the Rhamnaceae so well, and am therefore not competent to judge whether they resemble those of the Dichapetalaceae. On the other hand, I have considerable knowledge of the Euphorbiaceae and I cannot agree with Lobreau that Tapura pollen grains resemble those of certain Euphorbiaceae in the subfamily Phyllanthoideae. The most primitive genera in this subfamily have to be looked for in the vicinity of Securinega and, as far as I know, in this group of genera the pollen grains are different. They superficially resemble the pollen grains in the Tapura amazonica type in size, but shape, ornamentation, ectocolpi, and endoapertures are completely different. Moreover, other genera in the Phylanthoideae are even more different in their features.

Pollen grains of primitive Dichapetalaceae which resemble those of other families can be found, however, in some other publications. Lobreau (1967) published an evolutionary scheme of the genera of the Malpighiaceae. In this scheme the pictures of Galphimia and Byrsonima show a number of corresponding characteristics, such as size, microreticulum, triangular outline in polar view, and endocolpus. Of course, there are also important differences, such as the outline in equatorial view and the distinct costae. Thanikaimoni (1968) published a paper on the pollen morphology of the Menispermaceae and in this paper a number of pictures of pollen grains occur which resemble the primitive types of Dichapetalaceae remarkably well; viz. Cissampelos spec., Spirospermum penduliflorum, etc. It is 
a pity that he did not indicate primitive and advanced pollen types, and for that reason it is not possible to make reliable conclusions on the relationship of the pollen grains of the Menispermaceae with the Dichapetalaceae.

\section{Phy togeography}

The present distribution of taxa may be considered as the result of past migration. The principal questions therefore are what the place of origin might be and along which pathways the taxa migrated.

To get a better understanding of these problems it would have helped if fossil data (pollen grains as well as other parts of the plant) were available. However, polen grains of the Dichapetalaceae are rather inconspicuous, and palynologists working in Quaternary or Tertiary deposits have never reported pollen grains referable to the Dichapetalaceae. Other parts of the plant such as seeds, leaves, wood, etc. have, as far as I know, never been reported either.

As fossil data fail to provide any explanation of past migration it seems worth to consider the evolutionary trends in pollen grains as a possible help in solving migration problems. Reitsma $(1970 \mathrm{~b})$ has already suggested a possible contribution of pollenmorphology to the solving of migration problems. He accepted that pollen characters may evolve during migration of the taxon and that this evolution may be so quick that such a taxon does not show any external morphological variation whereas the pollen grains have already changed into different pollen types (e.g. Alangium chinense, Reitsma, 1970b). In Dichapetalum too some species show distinct differences in pollenmorphology within one species, whereas taxonomic investigation does not reveal any consistent differences between the specimens. The following three taxa are good examples of this phenomenon:

(1) Dichapetalum madagascariense. This species is widely distributed in Continental Africa and Madagascar. The East African specimens resemble those of Madagascar very closely, but the West African specimens differ widely (see p. 39). Following the gradual transitions from specimen to specimen and taking the evolutionary trends as a leading factor, it is clear that the West African specimens are morphologically more specialized. From these data a possible pathway for migration can be suggested along two lines:

(A) The place of origin is East Africa and the migration pathway was twofold: one leading eastwards towards the island of Madagascar and the second leading westwards towards West Africa.

(B) 'The place of origin of the taxon is Madagascar and the pathway of migration was from this island towards East Africa and subsequently the plants migrated further on towards West Africa.

(2) Dichapetalum zenkeri. This species has its widest distribution in West Africa. The pollen grains show a distinct differentiation in morphological features; most of the specimens have pollen grains of the $D$. zenkeri 
type, but a series of transitions exists between this type and two other types, the $D$. angolense type and the $D$. heudelotii type. In this species, however, it is difficult to trace the path way of migration or to suggest the place of origin. Perhaps a more detailed study of pollen grains of hundreds of specimens from as many geographical areas as possible will give more information about the geographical distribution patterns. Of course, such a detailed examination was outside the scope of this study.

(3) Dichapetalum timoriense. T'his is an extremely variable species, which occurs throughout Malesia with the exception of the island of Sumatra. On the other hand, when all specimens are taken together they seem to represent a natural entity. The same is true for the pollen grains of the species. All specimens have grains which undoubtedly belong to the same pollen type, but within this type there is extensive variation of minor features and consequently it is possible to reconstruct the pathway of migration. If the changing pollenmorphological features are taken in conjunction with the evolutionary trends, the most primitive representatives are found in the eastern part of Malesia, extending from New Guinea to the Philippines. The most primitive group in the $D$. timoriense type is the Luzoniense group which most resembles the $D$. papuanum type, a type also confined to the eastern part of Malesia. It is most likely, that the origin of the species could be expected to be in this geographical area.

More advanced pollen grains in this species (Sumbawense group) are found in specimens from the Lesser Sunda Islands, Java, Malaya and probably on the Philippines. The most advanced ones (Timoriense group) are only found on Greater Sunda Islands Java and Borneo, Malaya and the Philippines. From these data it seems likely that the Philippines have been invaded twice by this species; once via New Guinea and the Eastern Islands directly to the Philippines and again from Java via Borneo towards the Philippine Archipelago.

The fourth group in this species, the Malaccense group, is based on a single specimen only, which stands rather isolated among the other specimens. This specimen was first described as a separate species, $D$. malaccense, occurring in Malaya. From a pollenmorphological point of view the pollen grains resemble in a way the east Malesian specimens, but they are slightly more advanced with regard to their endoapertures. The pollen grains must be considered as a second line of evolution next to the line described above, but in the absence of intermediates between this group and the Luzoniense group from specimens occurring in the intervening area it is difficult to explain this second line more fully.

The occurrence of Dichapetalaceae in America, Africa and Asia raises the question of which continent should be regarded as the site of origin of the whole family. It is logical to look for the site of origin where the plants have the least advanced pollen grains. Such primitive pollen grains are present in Africa in the genera Dichapetalum ( $D$. bangii type) and Tapura ( $T$. amazonica type) and also in America in the genus Tapura ( $T$. amazonica type). As the genus Dichapetalum is only represented in America by a 
single, comparatively advanced pollen type, evidence points to an African origin for the genus Dichapetalum. In the genus Tapura, the pollen grains of the primitive Tapura amazonica type occur in America as well as in Africa and the place of origin of this genus seems less certain. According to the ideas taxonomists have about the phylogenetic relationship between Dichapetalum and Tapura the latter is said to be more advanced than the former.

Weighing up both gross morphological and palynological data it seems justifiable to accept Africa as the site of origin of the whole family.

In the following lines the geographical areas will be discussed separately.

\section{Madagascar}

The Madagascan species can be differentiated into three types. The most interesting is the Dichapetalum leucosia type, to which most of the Madagascan species belong. It is a rather primitive type resembling the $D$. bangii type in many characteristics, and it is also remarkable that a number of evolutionary trends such as interrupted muri and the sunken position of the apocolpium, which are characteristic of several different types on the African continent, are also present in the otherwise closely related pollen grains of different species in the $D$. leucosia type. This differentiation of the pollen characteristics comparable with those occurring on the African continent has to be considered a parallel development. It may be concluded that a single, rather primitive Dichapetalum species existed on Madagascar at the time the island was isolated from the continent and that subsequently the pollen grains have evolved along similar parallel lines.

Apart from this remarkable group of species, two other pollen types occur which are, however, of lesser interest. D. madagascariense, $D$. humbertii and $D$. multiflori belong to the $D$. madagascariense type, a type well represented on the $\Lambda$ frican continent which is one of the most advanced pollen types in Dichapetalum. This type must have reached Madagascar at a much later time.

The pollen grains of Dichapetalum chlorinum are also highly advanced, but it is not easy to comment on the phytogeography of this isolated pollen type.

\section{America}

In America only one Dichapetalum type, the D. pedunculatum type, occurs. Except for small and unimportant variations in the ornamentation, the pollen grains belonging to this type do not show much variance. The type is rather primitive in most features and seems to have failed to develop more advanced pollen grains. As in Madagascar it seems most likely that one ancestral species of Dichapetalum reached (or invaded) America, but as opposed to the situation in Madagascar the pollen grains failed to evolve further.

The genus Tapura shows a greater number of different pollen types, but here too most of the species belong to one, primitive type, the T. amazonica type which is also represented in Africa. Two other more advanced types, 
the $T$. coriacea and the $T$. juliani type, are isolated in the western part of South America and seem to indicate that if there has been any available pathway in South America it must have run from East to West.

Stephanopodium, which is only present in America, shows much advanced pollen grains that have a resemblance to those of the $T$. juliani type.

As no representatives occur in Africa, it is highly probable that this taxon has evolved after the disjunction of West Africa and South America.

Asia

Only one genus, Dichapetalum, is present in Asia. Its species can be divided into three groups of pollen types: (1) the $D$. papuanum type and $D$. timoriense type; (2) the $D$. gelonioides type and $D$. grandifolium type; and (3) the $D$. longipetalum type.

(1) The first group shows a number of primitive characteristics and is certainly related to the $D$. leucosia type and to a smaller extent to the $D$. bangii type. It is striking that these types occur in widely separated areas and the only explanation can be that they represent relicts of primitive taxa which have occupied a far larger area in former times.

The migration path of these primitive taxa is not certain, but if it is accepted that Africa is the site of origin of the family, it is logical to propose that its pathway must have run from West to East; from Africa, via Madagascar to Malesia. In more recent times, however, the relicts present in widely separated areas have continued evolving and it is highly probable that the migration of these newly expanding taxa is from East to West (p. 63) within Malesia.

(2) The second group of types is distinctly more advanced than the $D$. papuanum type, even in its most primitive representative $(D$. gelonioides type, Andamanicum group). It is striking that the taxa in this group are confined to the western part of Malesia, and from the evidence of the evolutionary trends it appears that the migration in this group has run from West to East, with the most primitive pollen grains on the Andamans, Sumatra, and Malaya and the more advanced ones concentrated in Borneo, the Philippines and 'Thailand (D. grandifolium type and D. gelonioides type, Tuberculatum group).

(3) The third group consists only of the D. longipetalum type, but this contains several species. Its features suggest a close relationship with the $D$. heudelotii type from Africa, but if convergence has occurred the type might be a highly advanced offshoot of the ancestral pollen type prior to the most primitive pollen group in the $D$. gelonioides type (Andamanicum group). The site of origin of the $D$. longipetalum type is unclear.

\section{Continental Africa}

Most of the pollen types occur in Continental Africa and all these types can be arranged in series from primitive to advanced. It is difficult to trace the migration paths of the different taxa with the exception of one species, Dichapetalum madagascariense (p. 39). In general, the most primitive 
pollen types are found in West and Central Africa while several more specialized pollen types are present in East Africa; viz. the D. macrocarpum type, $D$. barbosae type and $D$. barteri type p.p. Somewhat primitive pollen grains (e.g. D. angolense type, D. barteri type p.p.) occasionally occur in this part of Africa also.

According to pollenmorphological data it is highly probable that Africa is the place of origin of the whole family and it is certainly true that in Africa the evolution of the pollen grains has expanded to its highest degree in recent times.

\section{ACKNOWLEDGEMENTS}

Many thanks are due to the Directors and Curators of the herbaria for providing polleniferous material. The author wishes to thank especially Dr. F. J. Breteler for his stimulating discussions on the problems of the treated family. The author is very grateful to Dr. G. C. S. Clarke (British Museum, Nat. Hist., London) who read the manuscript critically, discussed it thoroughly with the author and finally brought the English text to a higher standard. Sincere thanks are due to Mr. J. Muller and Dr. Tj. Reitsma who also gave valuable criticism. The author is indebted to Mr. A. Elmont for making slides, to Mr. H. Rypkema for drawing the figures, and to Miss M. H. Langerak for typing the manuscript. 


\section{EXPLANATION OF PLATES}

PLATE I ( $\times 2000 ;$ p.68)

Dichopetalum cinereum Engler (Le Testu 7650)

1. Polar view; optical cross-section; convex sides.

2. Microreticulate ornamentation; lumina of about the same size, more or less rounded in outline; muri not interrupted.

3. Equatorial view; elliptic outline; poles not sunken.

4. Microreticulate ornamentation in equatorial view.

D. liberiae Engler et Dinklage (Breteler 5237)

5. Polar view; optical cross-section; sides nearly straight.

6. Equatorial view; elliptic outline; large endoaperture.

7. Microreticulate ornamentation; lumina of about the same size; muri not interrupted.

12. Short, rather wide colpus.

D. deflexum (Klotzsch) Engler (Carvalho s.n.)

8. Microreticulate ornamentation in equatorial view.

9. Microreticulate ornamentation in polar view; lumina angular in outline; muri continuous.

D. pallidum (Olivier) Engler (Zenker 2451)

10. Polar view; optical cross-section; sides straight or nearly straight; angles obtuse.

13. Short, narrow colpus with indistinct margins at high focus.

14. The same colpus at low focus.

15. Microreticulate ornamentation at low focus.

16. Microreticulate ornamentation at high focus; lumina of about the same size; muri continuous.

D. mossambicense (Klotzsch) Engler (Drummond et al. 3828)

1.1. Lalongate endoporus.

17. Microreticulate ornamentation; lumina of about the same size, angular in outline; muri continuous.

18. Equatorial view; elliptic outline; large endoaperture.

PLATE II ( $\times 2000 ;$ p.69)

D. angolense Chodat (Dinklage 1970)

1. Polar view; optical cross-section; straight or nearly straight sides; large endoapertures.

2. Microreticulate ornamentation; muri interrupted at the poles.

5. Equatorial view; optical cross-section; sunken poles.

D. zenkeri Engler (Mildbread 3913)

3. Microreticulate ornamentation; muri interrupted at poles.

4. Polar view; optical cross-section; large endoapertures.

D. costatum Breteler (Leeuwenberg 3739 )

6. Microreticulate ornamentation; muri continuous.

9. Polar view; small endoaperture.

D. angolense Chodat (Reygaert 1045)

7. Circular endoporus.

8. Inaperturate grain; microreticulate ornamentation overlaying the endoporus.

D. brazzae Pellegrin (Bequaert 6849)

10. Irregular ornamentation at apocolpium.

11. Polar view; optical cross-section; sexine slightly thinner than nexine.

12. Equatorial view; elliptic outline; large endoaperture.

D. dewevrei De Wildeman et Durand (Dacremont 213)

13. Ornamentation at high focus; muri thin.

14. Ornamentation at low focus; muri slightly thicker below. 


\section{PLATE I}
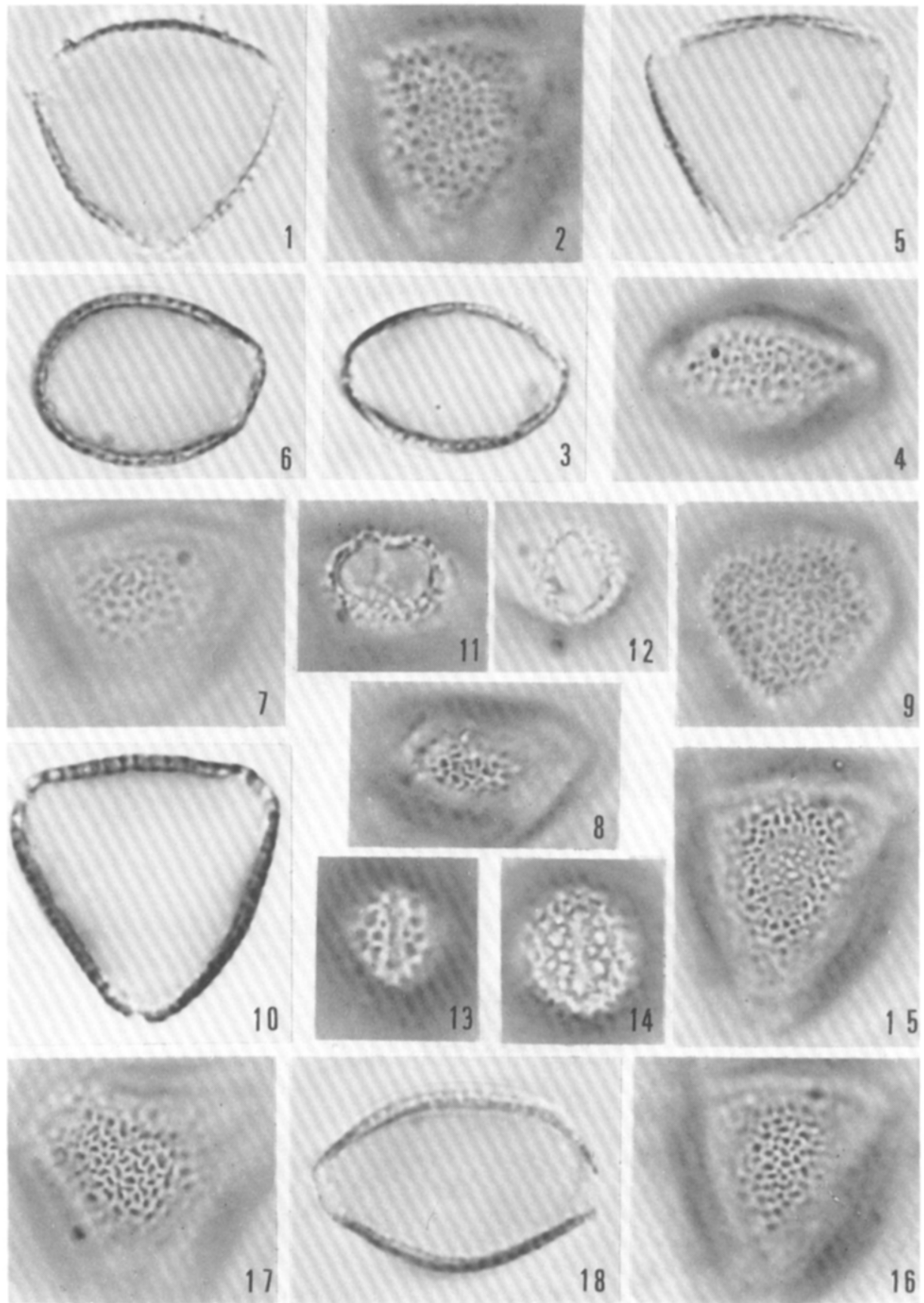


\section{PLATE II}
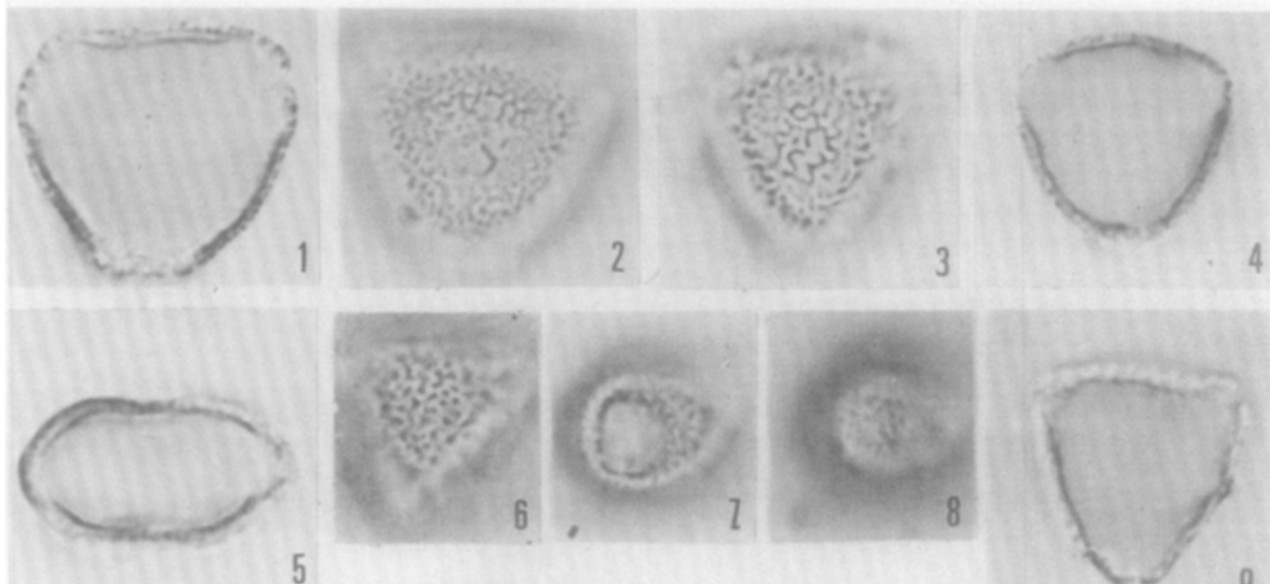

5
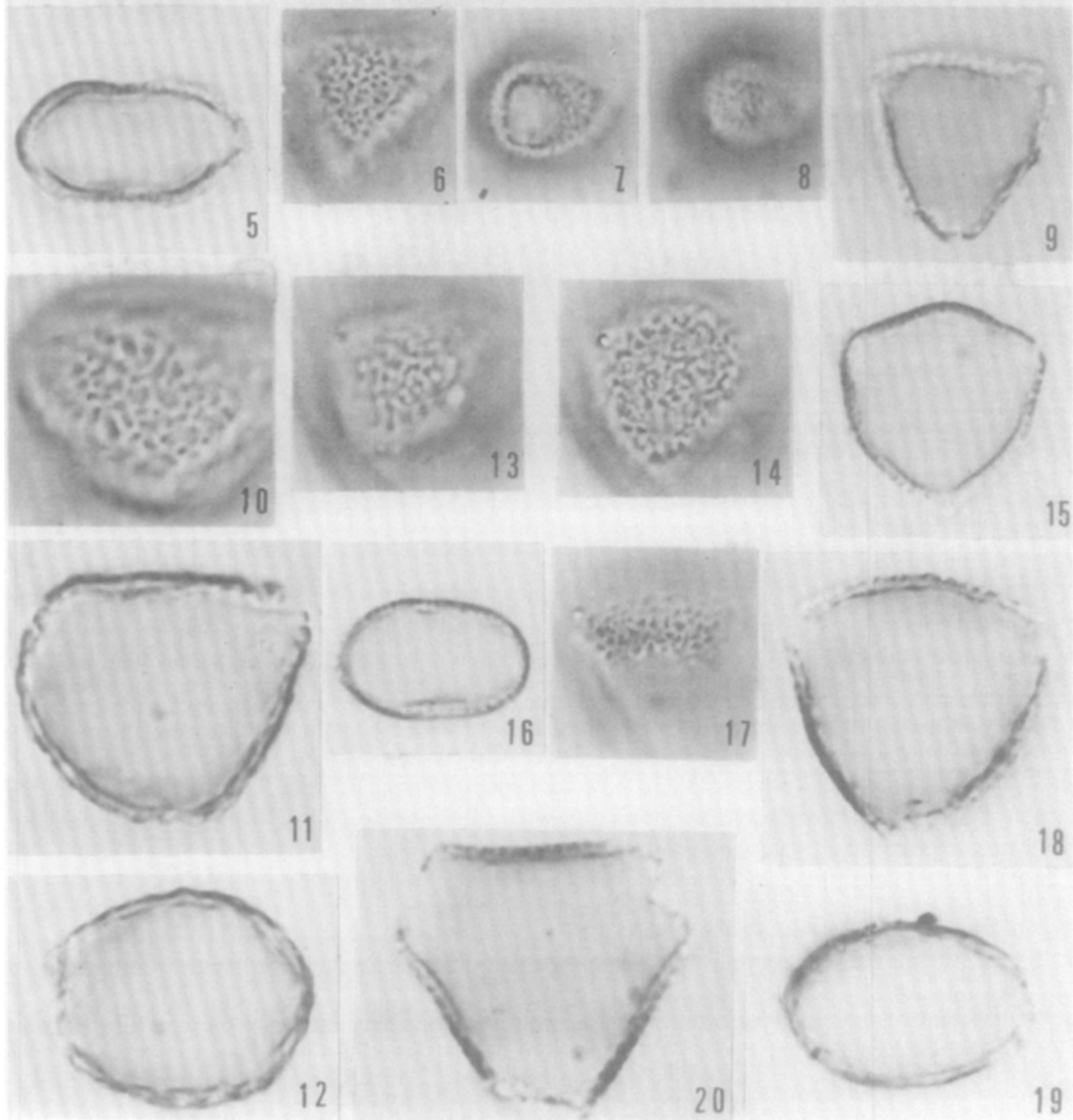
18. Polar view; optical cross-section; sides convex.

D. ugandense Moss (Dümmer 2445)

15. Polar view; optical cross-section; small endoaperture; sides convex.

16. Equatorial view; elliptic outline; distinct sunken poles.

D. bocageanum Henriques (Mann s.n.)

17. Microreticulate or namentation.

D. deweurei De Wildeman et Durand (Klaine 210)

19. Equatorial view; elliptic outline.

I). mossambicense (Klotzsch) Engler (Drummond et al. 3828)

20. Polar view; optical cross-section; sides straight or slightly concave; short, rather broad colpi; large endoapertures.

PLATE III $(\times 2000 ;$ p.71)

D. bangii (F. Didrichs) Engler (Tessmann 161)

1. Equatorial view; optical cross-section; small, but distinct fastigium.

2. Polar view; optical cross-section.

D. lujaei De Wildeman et Durand (Gossweiler 6073)

3. Reticulate ornamentation at apocolpium, low focus.

4. Reticulate ornamentation at apocolpium, high focus.

8. Indistinct, narrow endocolpus.

D. fructuosum Hiern (Troupin 4046)

5. Ectocolpus, rather broad.

6. Indistinct endocol pus.

7. Equatorial view; optical cross-section.

D. barbosae Torre (Barbosa 2085)

9. Equatorial view; pear-shaped, one colpus situated at one end; sexine elements in mesocolpial part.

10. Lolongate endocolpus.

11. Short and narrow ectocolpus.

12. Equatorial view; elliptic in outline, two apertures at the ends.

13. Polar view; optical cross-section; sides distinctly concave.

14. Ornamentation at apocolpium; microreticulate to tectum perforate

15. Equatorial view; optical cross-section.

l). arenarium Breteler (Schlieben 2651)

16. Polar view; optical cross-section; sides distinctly concave.

17. Ornamentation at apocolpium, low focus; broad base of muri.

18. Polar view; short to rather long colpi with faint costae.

PLATE IV $(\times 2000 ;$ p.72)

D. barteri Engler (Barter 1781)

1. Polar view; optical cross-section; sexine reduced, distinctly thinner than nexine; sides convex; angles subacute.

2. Indistinct ornamentation at apocolpium; muri thicker below.

D. integripetalum Engler (Zenker 3707)

3. Polar view; long colpi.

D. cymosum (Hooker) Engler (Bullock 11962).

4. Polar view; long colpi.

5. Polar view; optical cross-section; highly reduced sexine; sides nearly straight.

8. Equatorial view; pear-shaped outline; distinct sunken poles.

D. ruhlandii Engler (Sacleux 1875)

6. Equatorial view; optical cross-section; elliptic outline.

7. Polar view; optical cross-section; highly reduced sexine; distinct convex sides; obtuse angles. 


\section{PLATE III}
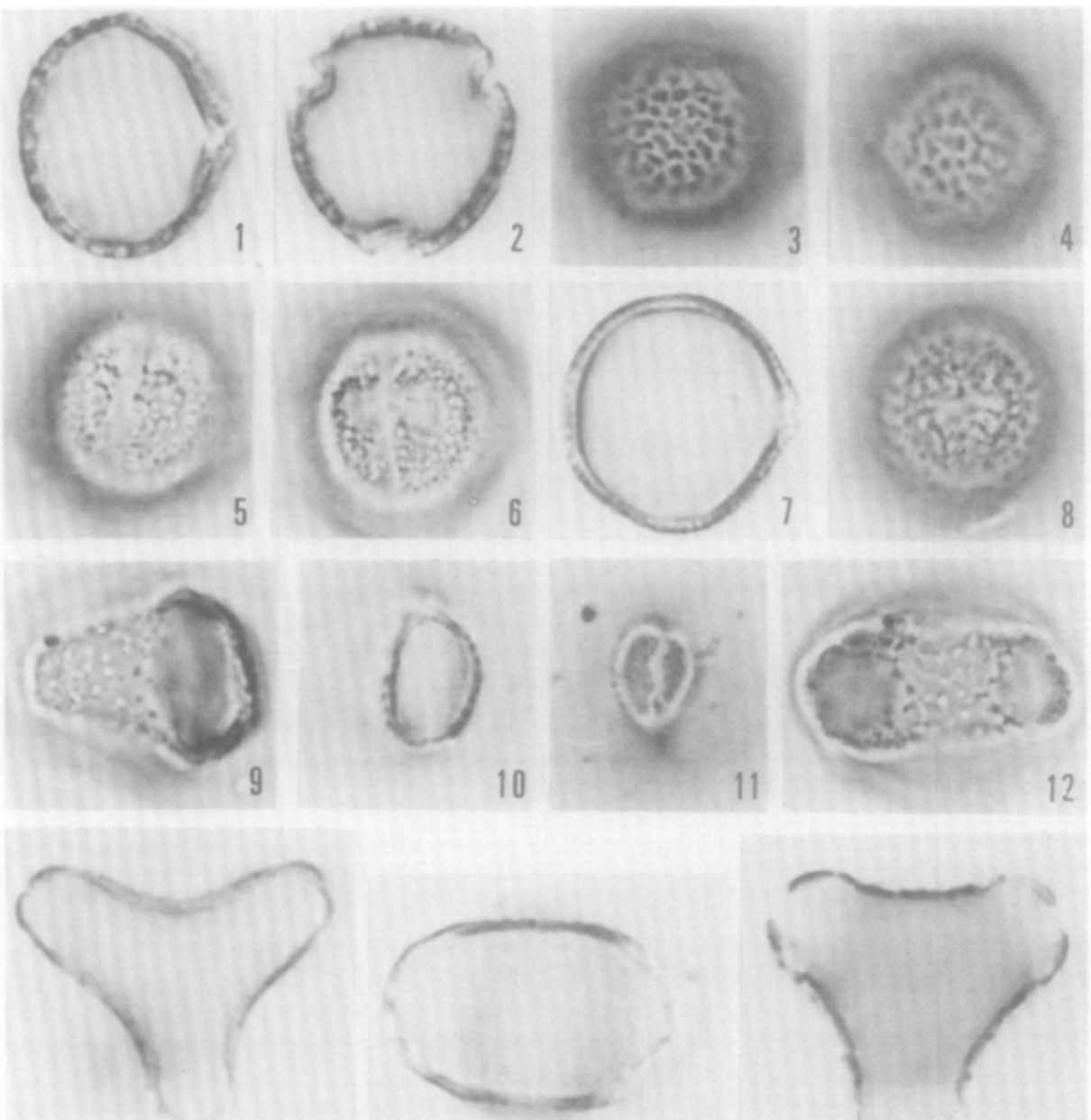

13

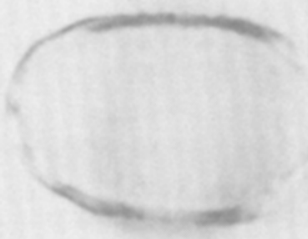

15
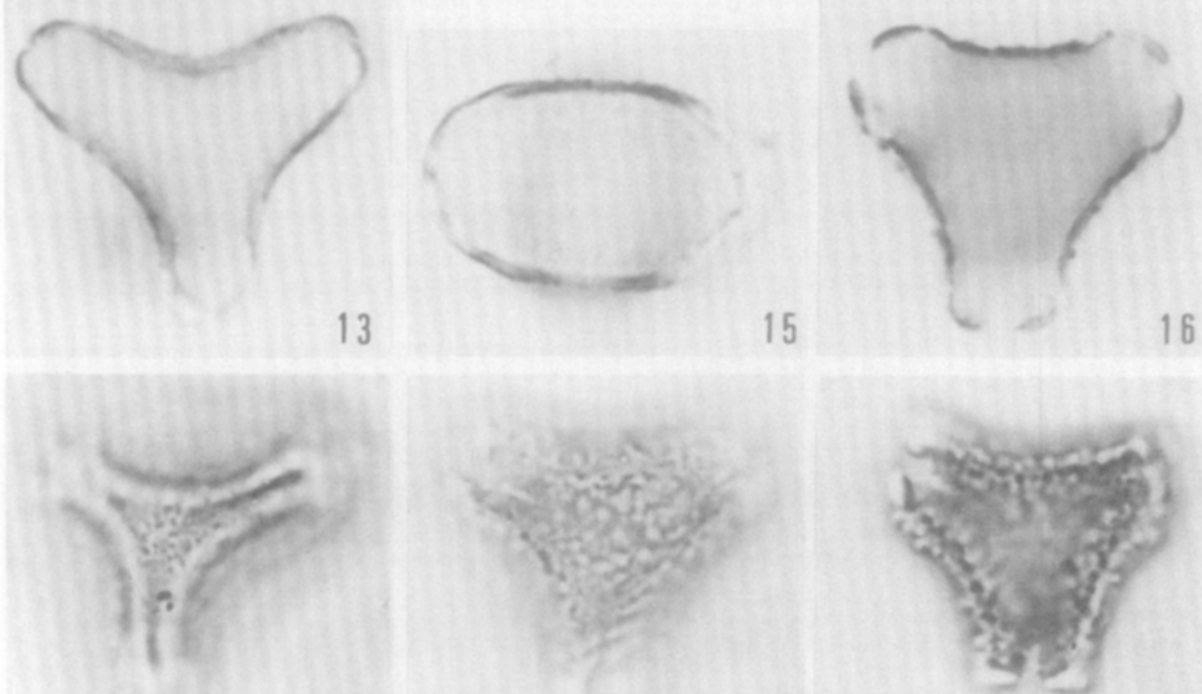

14

17

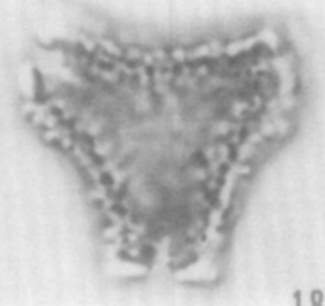




\section{PLATE IV}
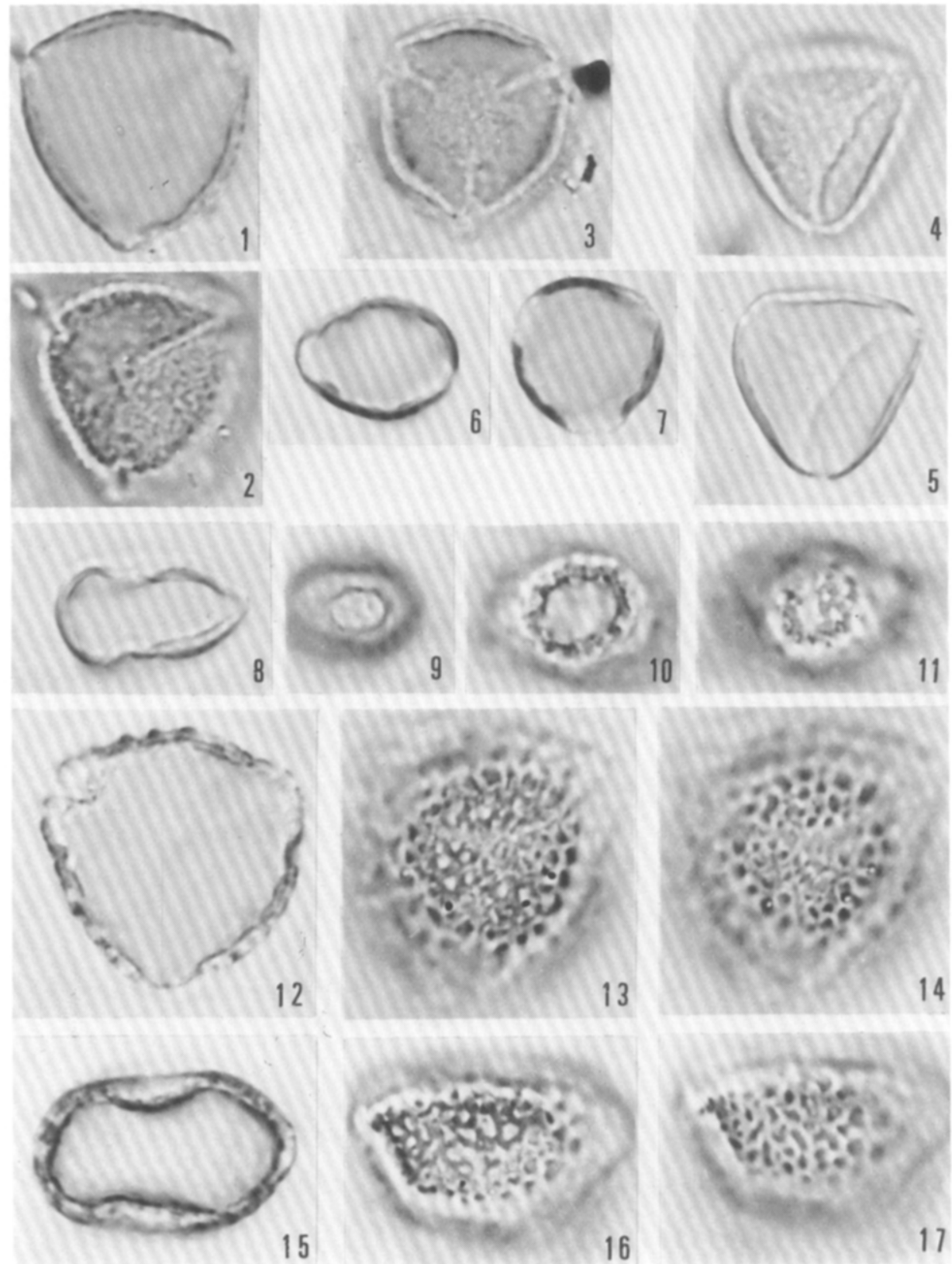
9. Slightly lalongate endoporus.

D. chlorinum (Tulasne) Engler (Perrier de la Bâthie 14956)

10. Circular endoaperture.

11. Narrow ectocolpus.

12. Polar view; optical cross-section; convex sides.

13. Ornamentation at apocolpium; low focus; muri broad at base; colpi nearly syncolpate.

14. Ornamentation at apocolpium, high focus; lumina smaller at apocolpium than towards the mesocolpium; muri thin at top.

15. Equatorial view; optical cross-section; sunken poles.

16. Equatorial view; ornamentation at low focus; broad muri at base.

17. Equatorial view; ornamentation at high focus; lumina irregular in outline; muri thin at top.

PLA'TE V ( × 2000; p.74)

D. choristilum Engler (figs.1-4: Leeuwen berg 5595; figs.5-8: Leeuwenberg 5521)

1. Polar view; optical coss-section; sides straight to slightly concave.

2. Polar view; ornamentation at low focus; muri slightly thicker at base.

3. Microreticulate to reticulate ornamentation at high focus; muri thin at top; lumina size larger at apocolpium than towards the colpi.

4. Equatorial view; optical cross-section; elliptic outline.

5. Equatorial view; optical cross-section; pear-shaped outline.

6. Equatorial view; microreticulate ornamentation.

7. Narrow, rather long colpus.

8. Large, circular endoporus.

D. crassifolium ('hodat (figs.9, 13,14: Le Testu 6479; figs.10 12: Mildbread 2203)

9. Equatorial view; optical cross-section; elliptic outline; poles not or only slightly sunken.

13. Polar view; ornamentation at low focus.

14. Polar view; coarse reticulum at high focus; muri slightly interrupted at poles.

10. Equatorial view; microreticulate ornamentation; size of rounded lumina distinctly smaller than at apocolpium.

11. Polar view; optical cross-section; sides slightly convex to nearly straight.

12. Polar view; long colpi.

PLATE VI ( $\times 2000 ; p .75)$

D. gelonioides (Roxburgh) Engler ssp. andamanicum (King) Leenhouts (King's Collector 316)

1. Polar view; optical cross-section.

2. Equatorial view; optical cross-section; slightly pear-shaped in outline.

3. Polar view; ornamentation at low focus.

4. Reticulate to microreticulate ornamentation at high focus.

D. gelonioides (Roxburgh) Engler ssp. sumatranum (Miquel) Leenhouts (figs. 5-7: Clemens 26862; figs. 8, 9: Rahmat 807)

5. Polar view; optical cross-section; short colpi.

6. Polar view; ornamentation at low focus; distinct grooves in sexine.

7. Sexine grooves at high focus.

8. Fquatorial view; elliptic outline; indistinct endoaperture.

9. Equatorial view; tectum perforatum.

D. gelonioides (Roxburgh) Engler ssp. gelonioides (figs.10, 11: Kerr 16902; fig. 12: Kerr 21346)

10. Colpus with rounded ends.

11. Equatorial view; optical cross-section; faint costae. 


\section{PLATE V}
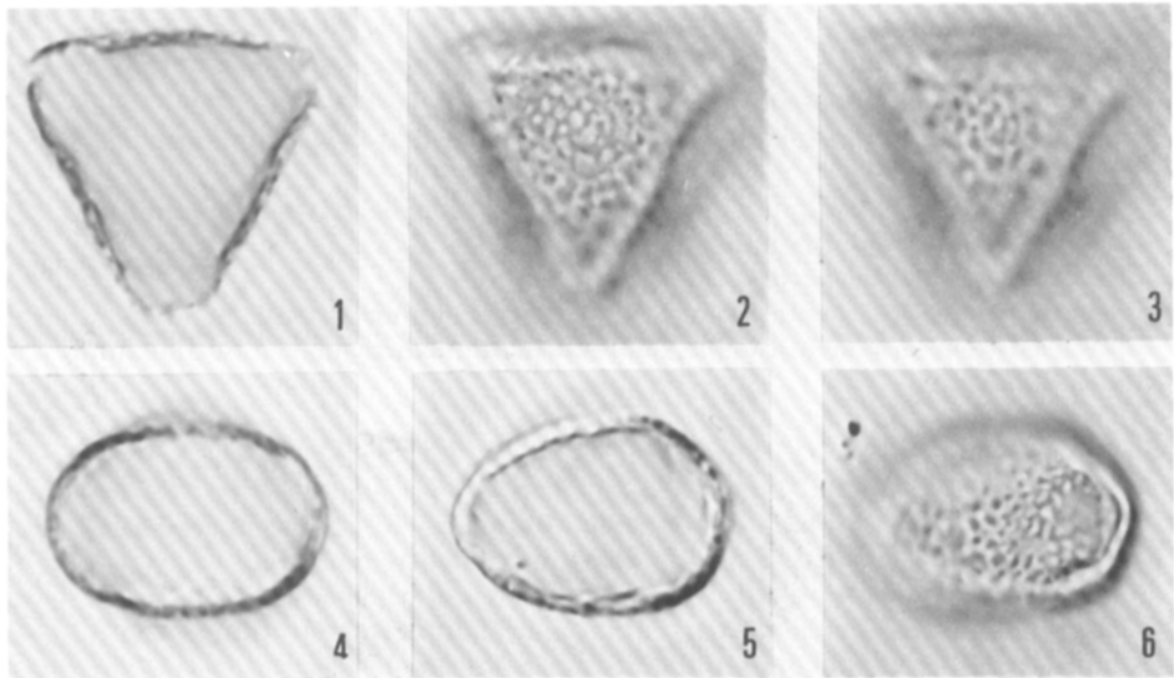

3
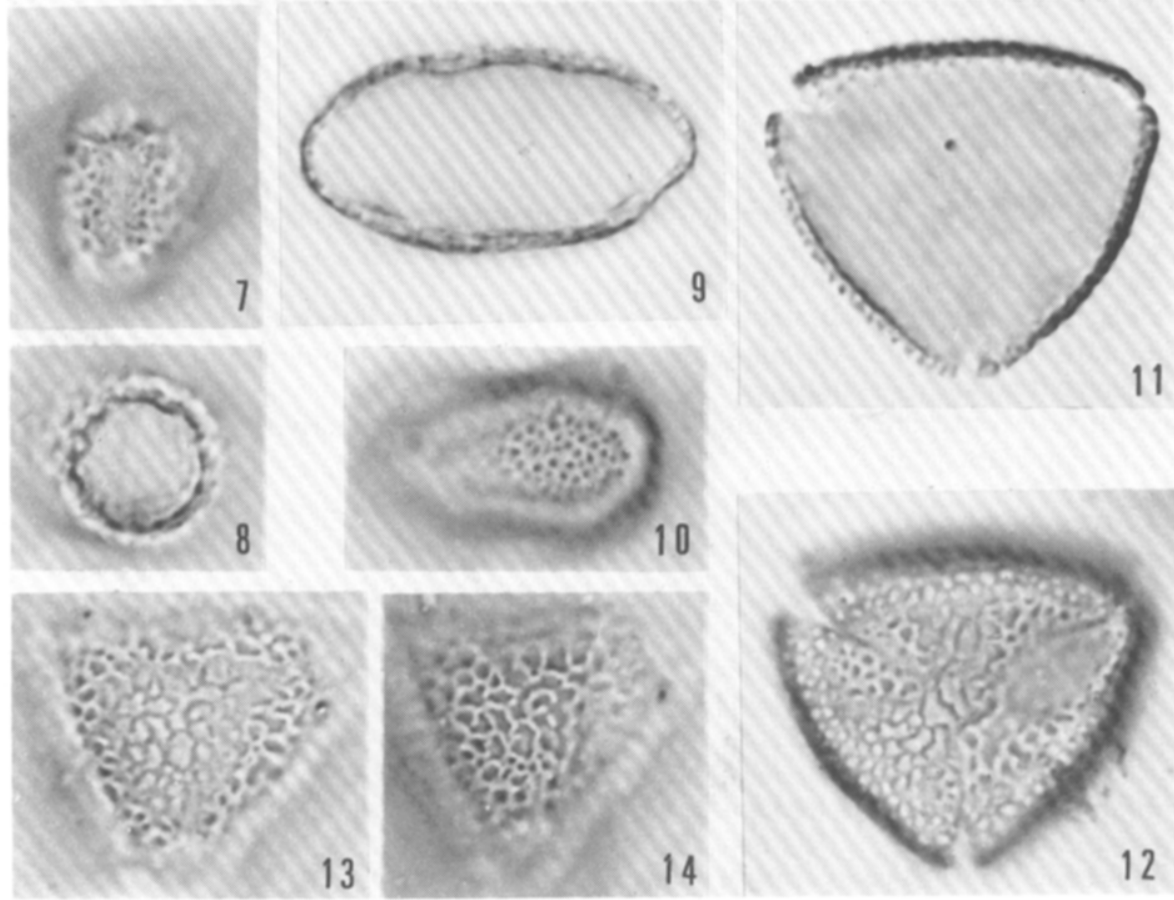


\section{PLATE VI}

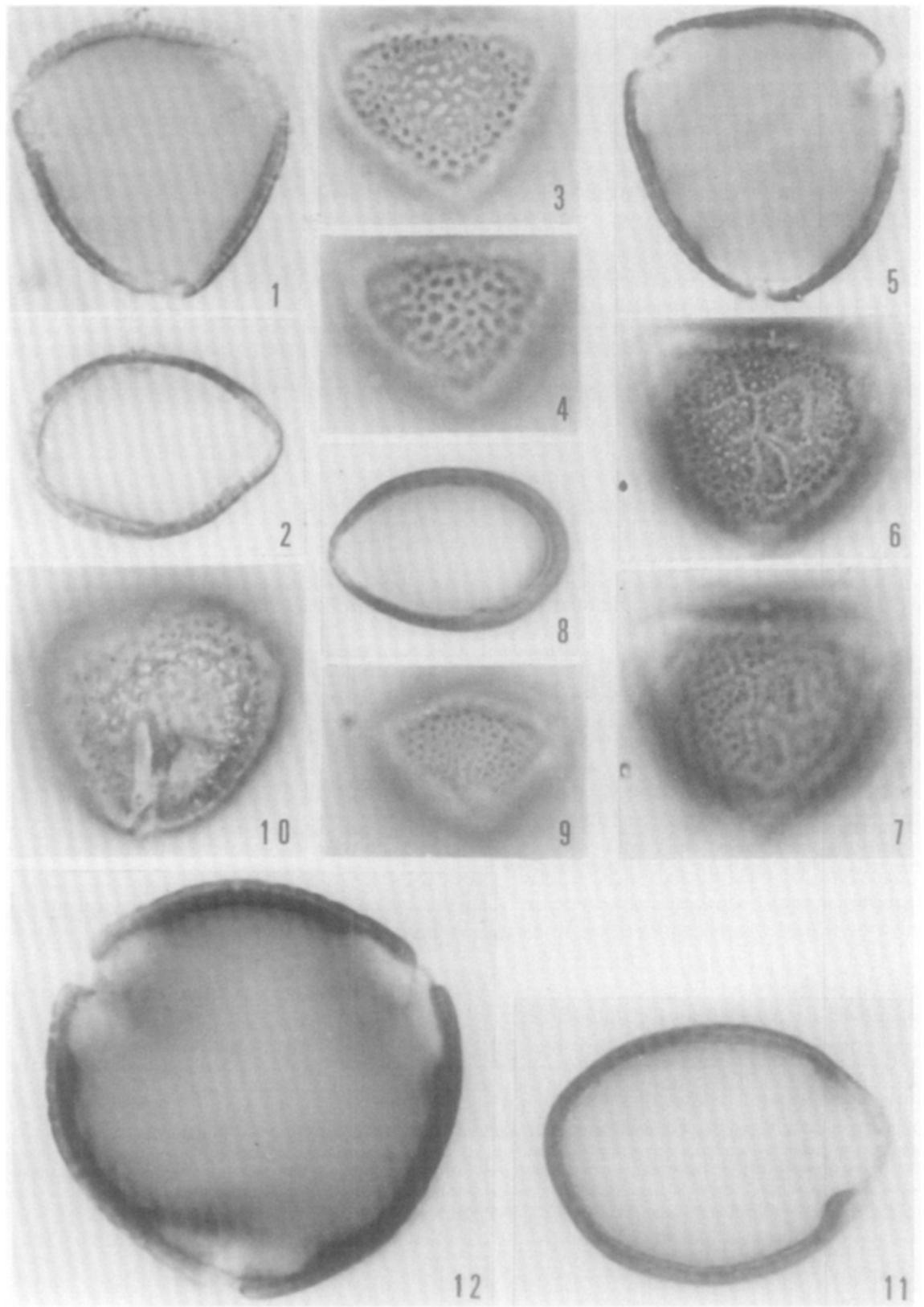


12. Polar view; optical cross-section; large endoapertures.

PLATE VII $(\times 2000 ;$ p.77 $)$

D. gelonioides (Roxburgh) Engler ssp. gelonioides (Kerr 21346 )

1. Polar view; ornamentation at low focus.

2. Tectum perforatum; ornamentation at high focus.

3. Distinct, large endoaperture, lalongate.

D. gelonioides (Roxburgh) Engler ssp. pilosum Leenhouts (fig.4: Frake 593; figs.5-8: Sandakan 64730)

4. Equatorial view; optical cross-section; elliptic outline.

5. Polar view; optical cross-section; distinct endoapertures.

6. Tectum perforatum: ornamentation at high focus.

7. Polar view; ornamentation at low focus.

8. Distinct, circular endoporus.

D. gelonioides (Roxburgh) Engler ssp. tuberculatum Leenhouts (fig.9: Elmer 12211; fig. 10: Elmer 12121; Fig.11: Elmer 12284)

9. Polar view of 4-colporate pollen grain; optical cross-section; rather short colpi with acute ends.

10. Equatorial view; optical cross-section; elliptic in outline.

11. Polar view of 3-colporate pollen grain; optical cross-section; short colpi with acute ends.

PLATE VIII ( $\times 2000 ; p .78)$

I). gelonioides (Roxburgh) Engler ssp. tuberculatum Leenhouts (figs.1, 2: Elmer 12121 ; fig. 3: Elmer 12284);

1. Microreticulate ornamentation tending towards a tectum perforatum at high focus.

2. Polar view; ornamentation at low focus.

3. Distinct, lalongate endoaperture with faint costae.

1). helferianum (Kurz) Pierre (figs.4-7: Put 832; fig.8: Kerr 16635)

1. Polar view; optical cross-section; large, distinct endoapertures.

5. Equatorial view; optical cross-section; elliptical outline.

6. Microreticulate to tectate ornamentation at high focus.

7 . Distinct, large, lalongate endoaperture.

8. Colpus; ends acute.

D. acuminatum De Wildeman (Louis 6339)

9. Polar view; optical cross-section; distinctly obtuse angles and large endoapertures.

10. Large endoaperture.

11. Ectocolpus; short and rather broad.

12. Ornamentation; pila at low focus, inordinately arranged.

13. Ornamentation; pila at high focus.

D. reticulatum Engler (Zenker 752 )

14. Polar view; optical cross-section; obtuse angles with distinct margo.

PLATE IX $(\times 2000 ;$ p.79 $)$

D. reticulatum Engler (Zenker 752 )

1. Ornamentation; pila at low focus, inordinately arranged.

2. Ectocolpus with interrupted margo and acute ends.

3. Equatorial view; optical cross-section; elliptic outline.

1. Distinct margo.

5. Lalongate, large endoaperture.

D. setosum Leenhouts (B.B.S. 26106) 


\section{PLATE VII}
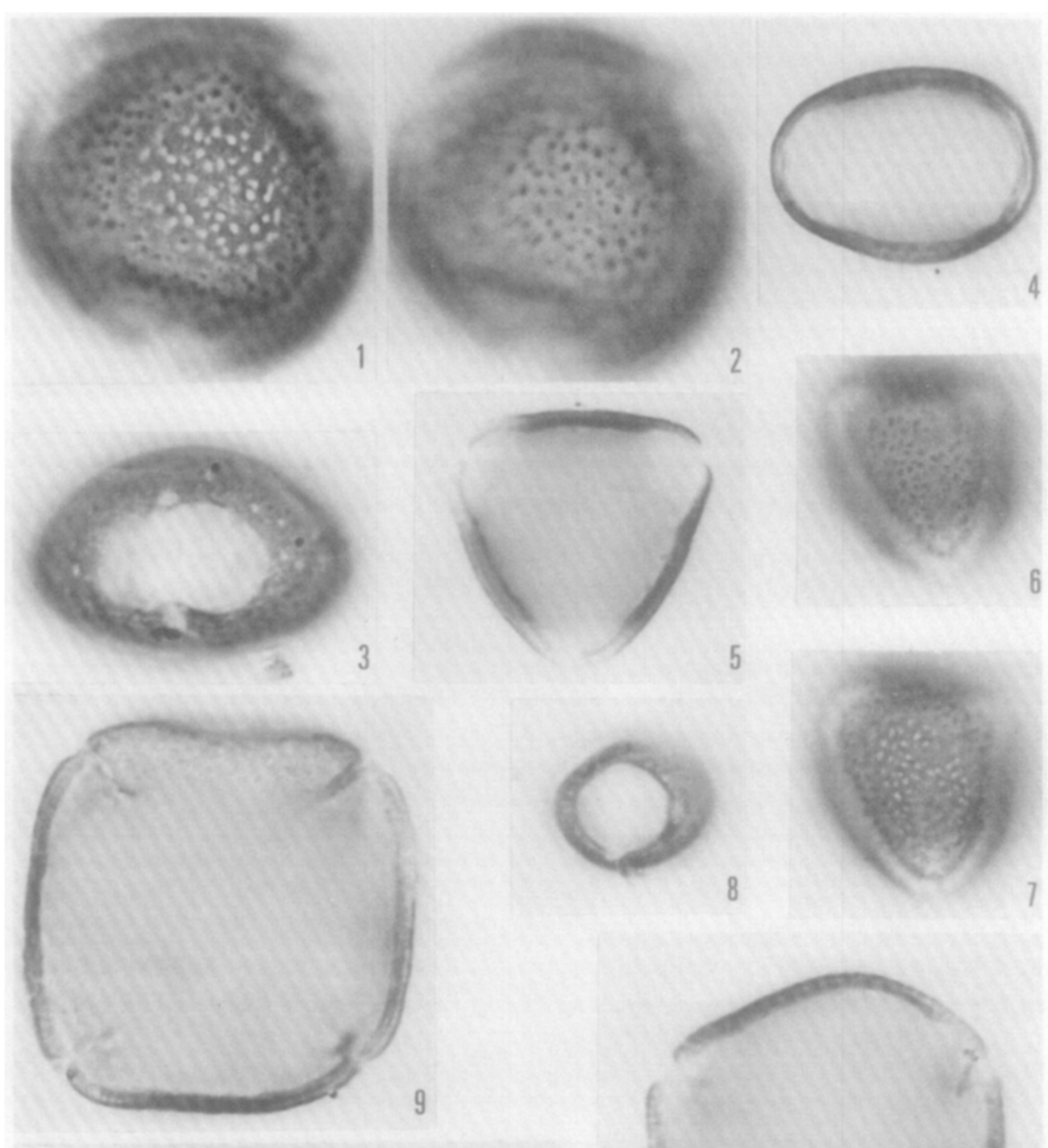

5

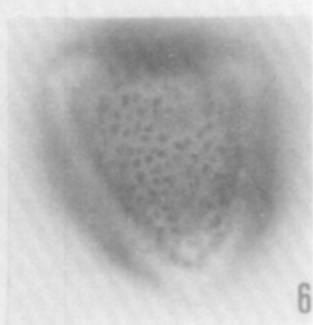

8
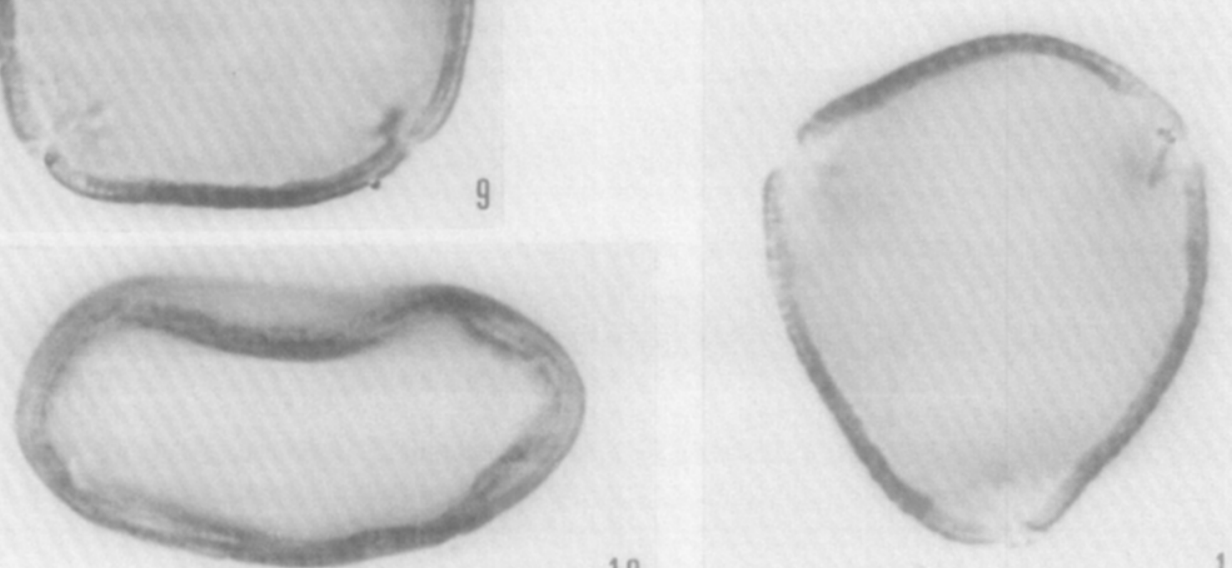


\section{PLATE VIII}
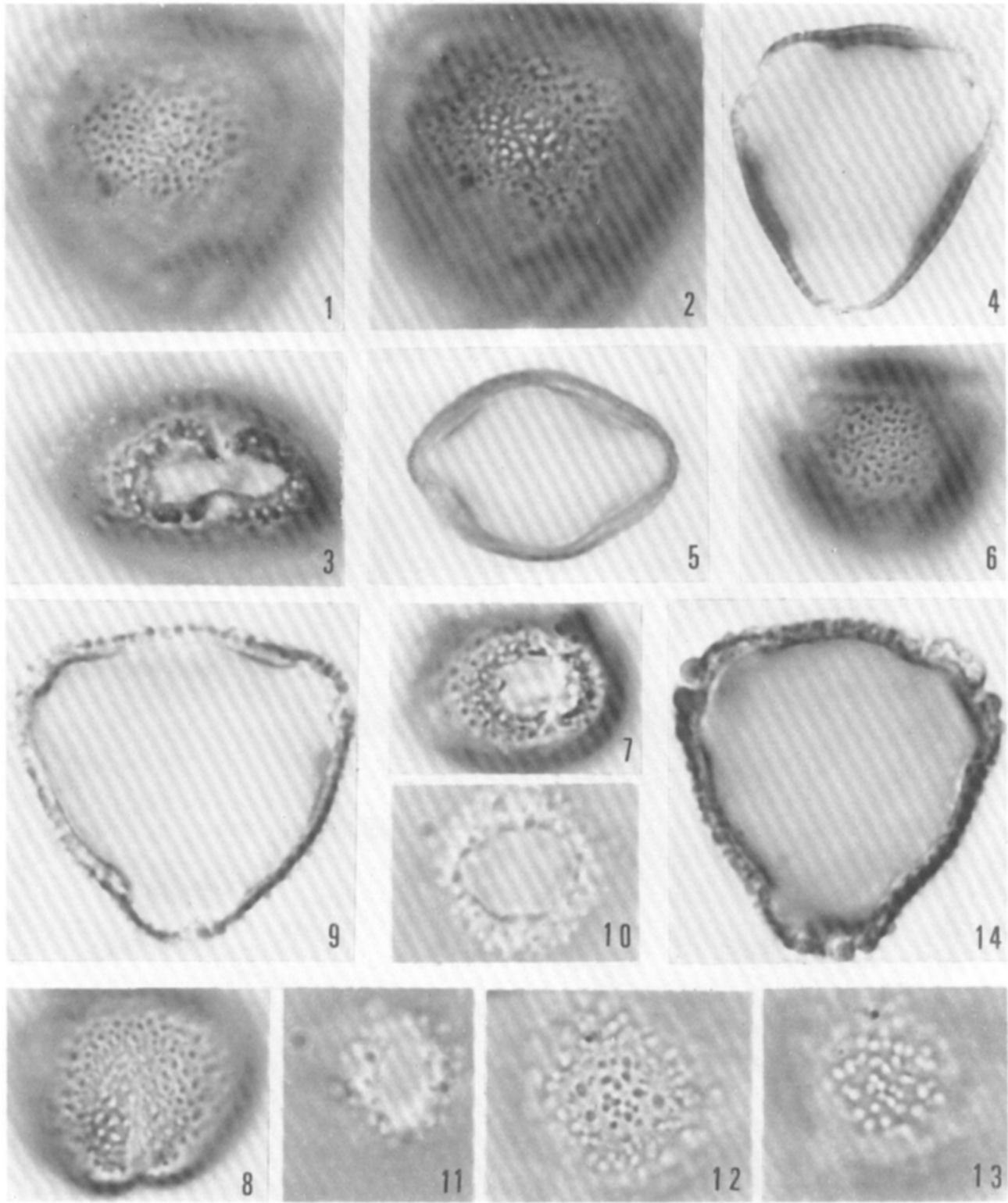
PLATE IX

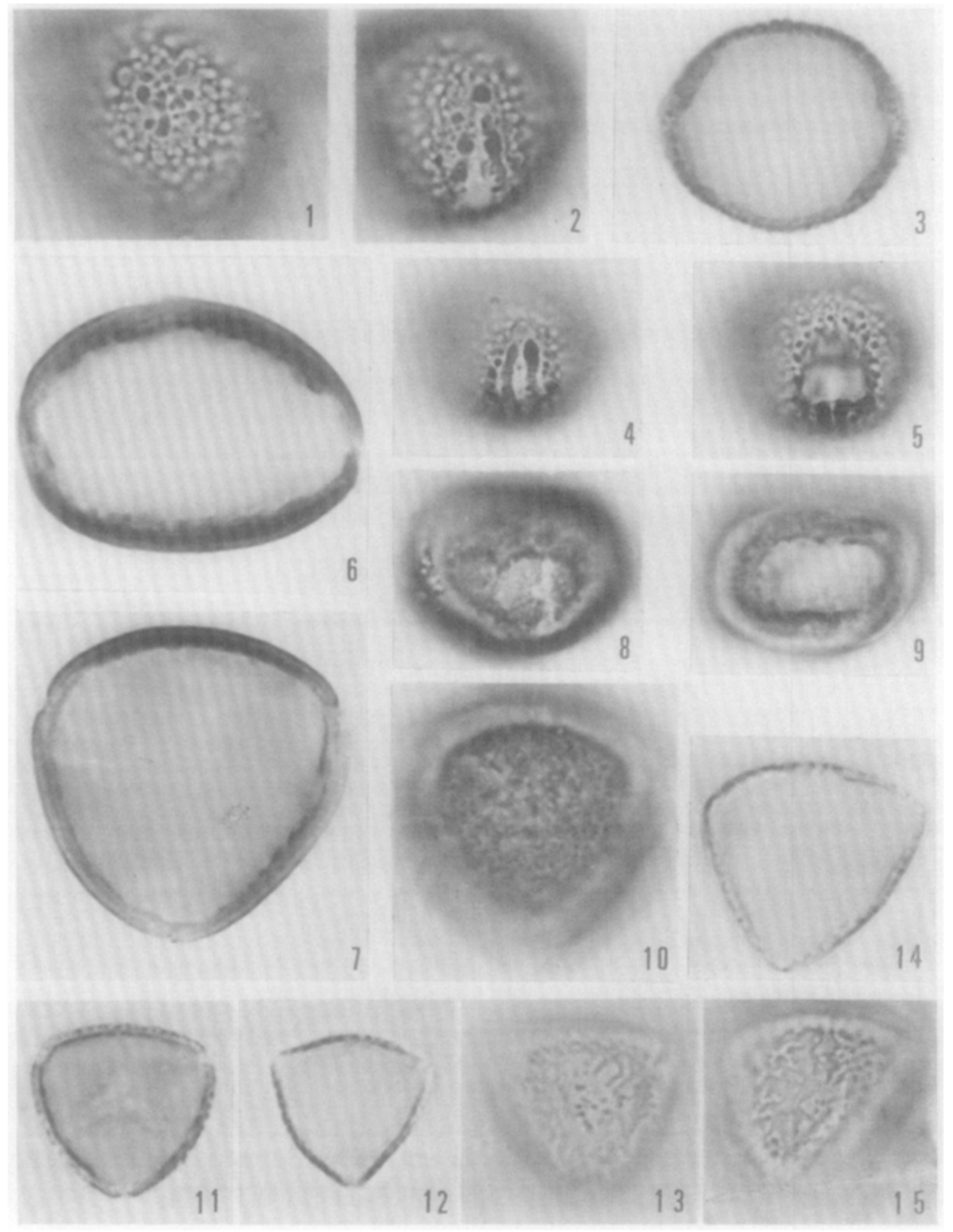




\section{PLATE X}
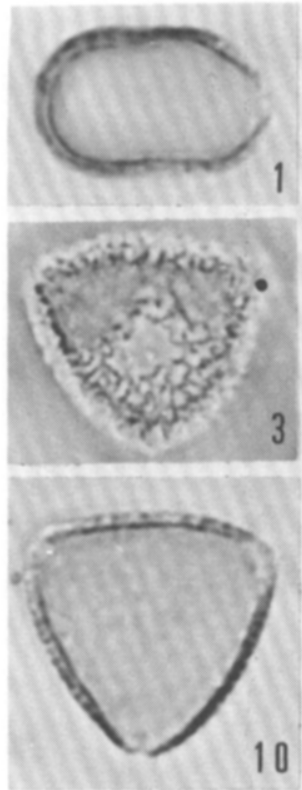

10
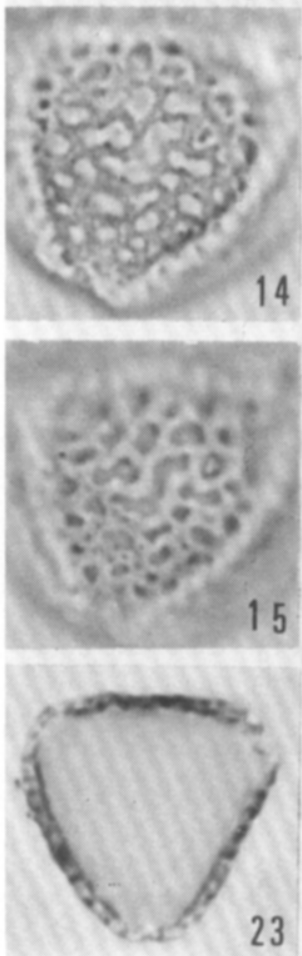
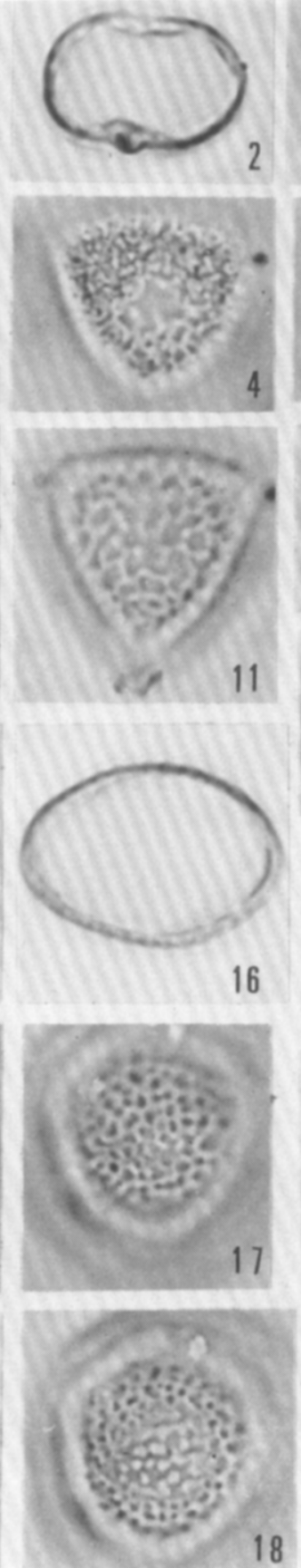
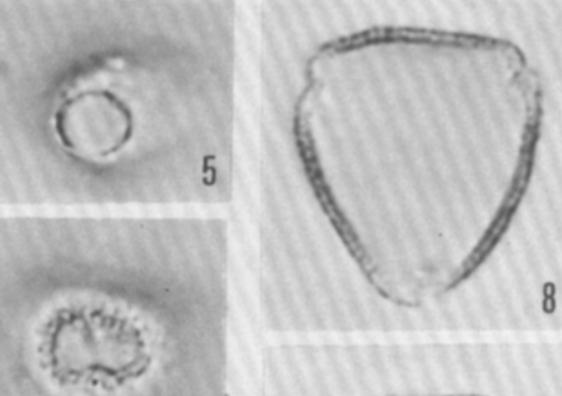

8
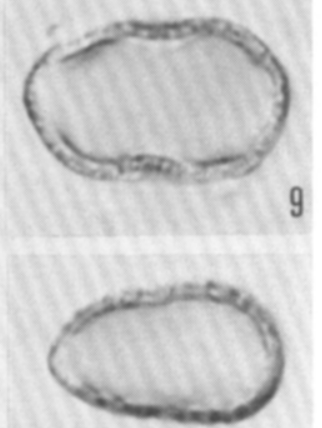

13
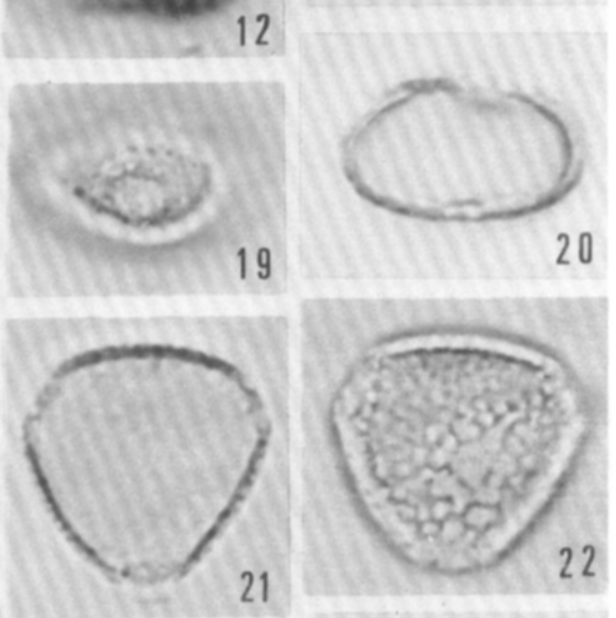

22
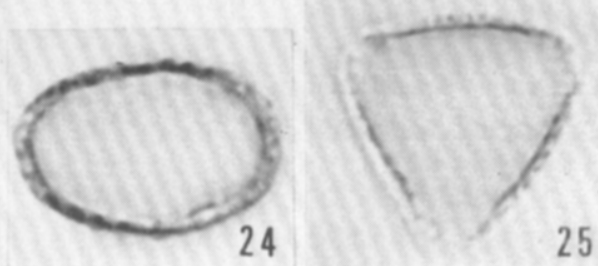
6. Equatorial view; optical cross-section; thick exine; elliptic outline.

7. Polar view; optical cross-section.

8. Ectocolpus, short and with irregular margins.

9. Endoacolpus, large and lalongate.

10. Polar view; ornamentation at low focus.

D. heudelotii (Planchon ex Olivier) Baillon (Scott-Elliott 5226)

11. Polar view; optical cross-section; thin exine; indistinct small endoapertures; sides nearly straight; angles subacute.

13. Polar view; ornamentation at apocolpium; interrupted muri.

D. ndongense Engler (Breteler 5829)

12. Polar view; optical cross-section; very thin exine; indistinct small endoapertures; angles subacute.

D. hispidum (Olivier) Baillon (Mann 1821)

14. Polar view; optical cross-section; thin exine; indistinct small endoapertures; angles subacute.

15. Polar view; ornamentation at apocolpium; distinct interrupted muri.

PLATE X $(\times 2000 ;$ p.80 $)$

D. heudelotii (Planchon ex Olivier) Baillon (figs. 1, 25: Mann 800; fig. 2: Zenker 3874)

1. Equatorial view; optical cross-section; elliptic outline; sunken poles.

25. Polar view; optical cross-section; sides nearly straight; angles subacute.

2. Equatorial view; optical cross-section; exine very thin.

D. unguiculatum Engler (Pynaert 1418)

3. Polar view; ornamentation at low focus; muri distinctly interrupted at poles.

4. Ornamentation at apocolpium, high focus; lumina irregular.

6. Indistinct, lalongate endoaperture.

8. Polar view; optical cross-section; columellae more or less distinct.

9. Equatorial view; optical cross-section; sunken poles.

D. heudelotii (Planchon ex Olivier) Baillon (Sitha 1891)

5. Small, circular endoporus.

D. cymulosum (Olivier) Engler (Bos and Breteler 3066)

7. Indistinct endoaperture.

23. Polar view; optical cross-section; colpi very short.

24. Equatorial view; optical cross-section; elliptic outline; poles not or only slightly sunken.

D. oblongum (J. D. Hooker ex Bentham) Engler (Zenker 4069)

10. Polar view; optical cross-section; sides slightly convex; angles subacute.

11. Polar view; coarse reticulum at apocolpium: muri interrupted.

12. Equatorial view; microreticulate ornamentation.

13. Equatorial view; optical cross-section; sunken poles.

D. virchowii (O. Hoffmann et Hildebrandt) Engler (Hildebrandt 3193)

14. Polar view; coarse reticulum at low focus.

15. Ornamentation at high focus; muri thick, interrupted; lumina decreasing towards the angle where the endoaperture is situated.

D. bojeri (Tulasne) Engler (Humbert et Perrier de la Bâ thie 2358)

16. Equatorial view; optical cross-section; elliptic in outline.

17. Ornamentation at high focus; muri not interrupted.

18. Microreticulate ornamentation at low focus.

D. nigrescens (Tulasne) Baillon (Hildebrandt 3284 ).

19. Small, circular endoaperture.

20. Equatorial view; optical cross-section; sunken poles.

21. Inaperturate grain in polar view; optical cross-section; angles obtuse.

22. Polar view; ornamentation at apocolpium; lumina decreasing towards the angles; muri interrupted. 
PLATE XI ( $2000 ; p .83)$

\section{I). longipetalum (Turczaninov) Engler}

1. Polar view; optical cross-section; sides nearly straight (Poilane 10136).

2. Polar view; coarse reticulum; distinct interrupted muri (Balansa 3328).

3. Polar view; coarse reticulum at low focus (Saleh 31799).

4. Polar view; reticulum at high focus; lumina irregular in outline and large in size (Saleh 31799).

5. Rather indistinct, lalongate endoaperture (Poilane 10133).

6. Ectoaperture, small and narrow (Poilane 10133).

7. Inaperturate pollen grain; ornamentation overlaying the endoaperture (Balansa 3328 ).

8. Short ectocolpus with acute ends; lumina bordering the colpi distinctly smaller in size than those at the apocolpium (Poilane 10136).

9. Equatorial view; optical cross-section; sunken poles (Saleh 31799).

D. macrocarpum Engler

10. Polar view; optical cross-section; thick exine; sexine distinctly thicker than nexine; straight or nearly straight sides; angles obtuse (Schlieben 5832).

11. Equatorial view; optical cross-section; elliptic outline (Schlieben 5356).

12. Ornamentation at apocolpium, low focus (Schlieben 5832).

13. Ornamentation at apocolpium, high focus (Schlieben 5832).

D. toxicarium (G. Don) Baillon (Breteler 6062)

14. Polar view; optical cross-section; thin exine; short colpi.

PI.ATE XII ( $\times 2000 ;$ p.84)

D. mombuttense Engler (Sitha 736)

1. Polar view; optical cross-section; sides convex; angles subacute.

2. Polar view; pilate ornamentation at high focus.

3. Polar view; pilate ornamentation at low focus.

4. Equatorial view; microreticulate to tectate ornamentation at high focus.

5. Equatorial view; optical cross-section; sunken poles.

D. toxicarium (G. Don) Baillon (Breteler 6062)

6. Polar view; pilate ornamentation at low focus.

D. mundense Engler (figs.7, 8: Le 'Testu 8510; figs.9, 10: Breteler 205:)

7. Polar view; optical cross-section; sexine thinner than nexine.

8. Polar view; pilate ornamentation.

9. Equatorial view; optical cross-section; pear-shaped outline.

10. Equatorial view; pilate ornamentation overlaying the endoaperture.

D. papuanum (Beccari) Boerlage (fig. 11 : v. Leeuwen 10606; figs.12-15: B.S.I.P. 11802)

11. Ectocolpus; short, narrow and with irregular margins.

12. Ornamentation at low focus; muri simplicolumellate.

13. Ornamentation at high focus; microreticulum to reticulum.

14. Polar view; optical cross-section; thick exine; sexine thicker than nexine.

15. Polar view of 4 -colporate pollen grain; optical cross-section.

D. vitiense (Seemann) Engler (Smith 6504)

16. Polar view of 4-colporate pollen grain; optical cross-section.

PLATE XIII ( $\times 2000 ;$ p.85)

D. papuanum (Beccari) Borrage (v. Lecuwen 10606 )

1. Polar view; optical cross-section; angles very obtuse, outline nearly sexangular.

2. Licroreticulate ornamentation.

D. vitiense (Seemann) Engler (Smith 6501)

3. Equatorial view; optical cross-section; elliptic outline.

D. parvifolium Engler (Gossweiler 8986) 


\section{PLATE XI}
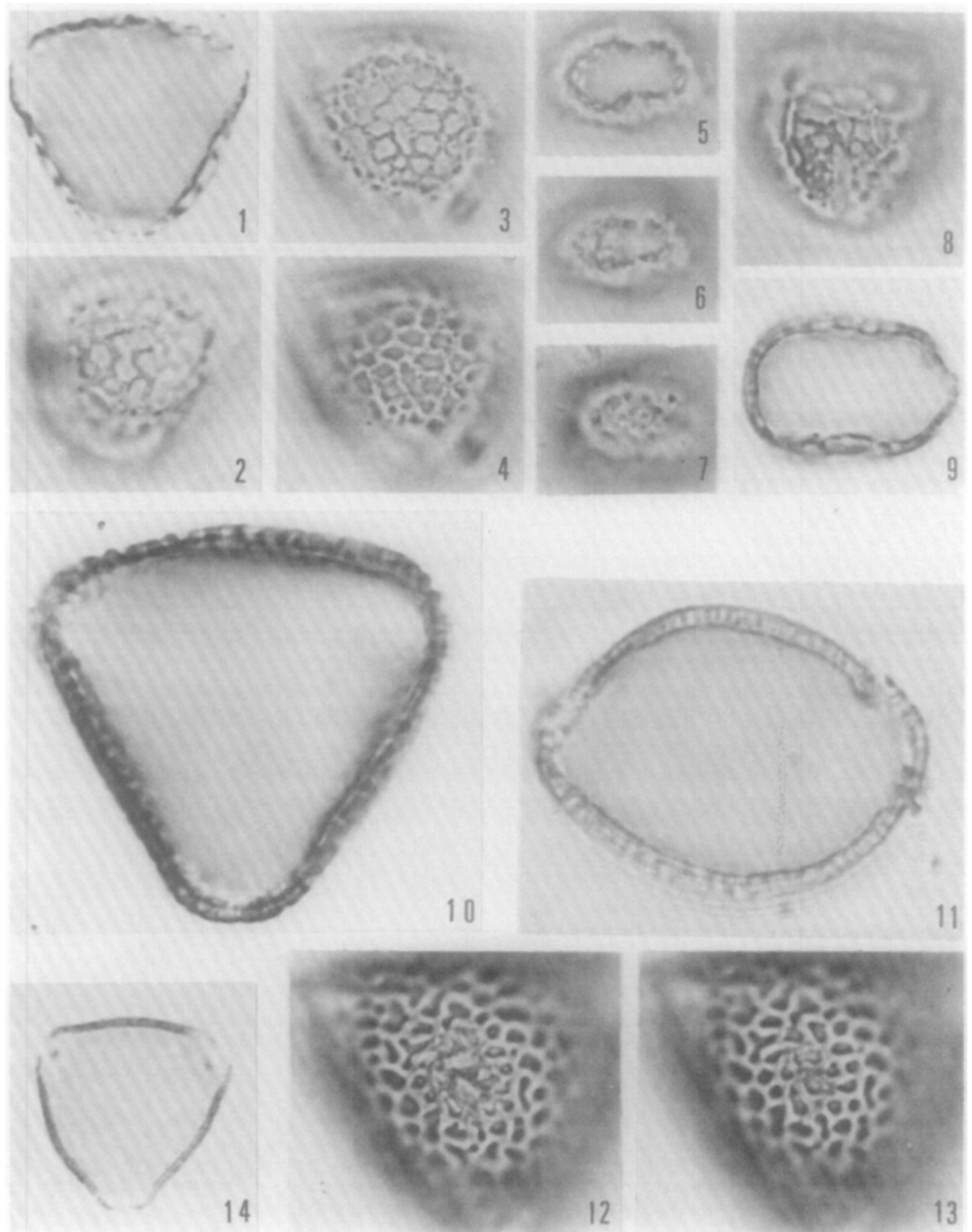


\section{PLATE XII}
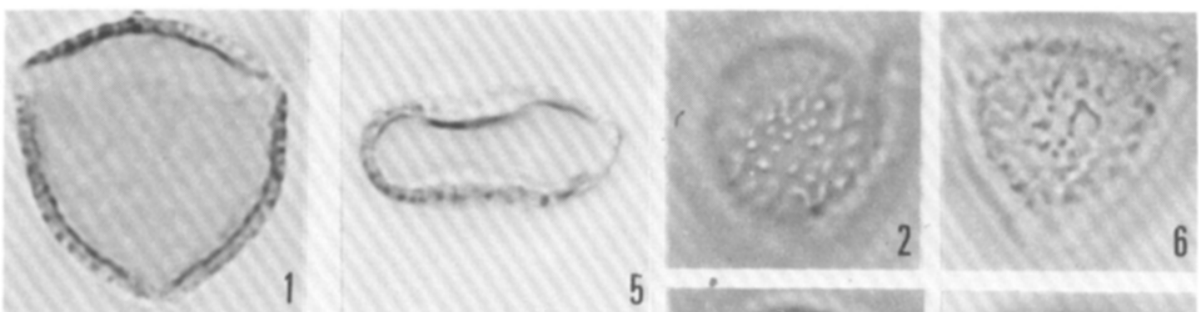

5
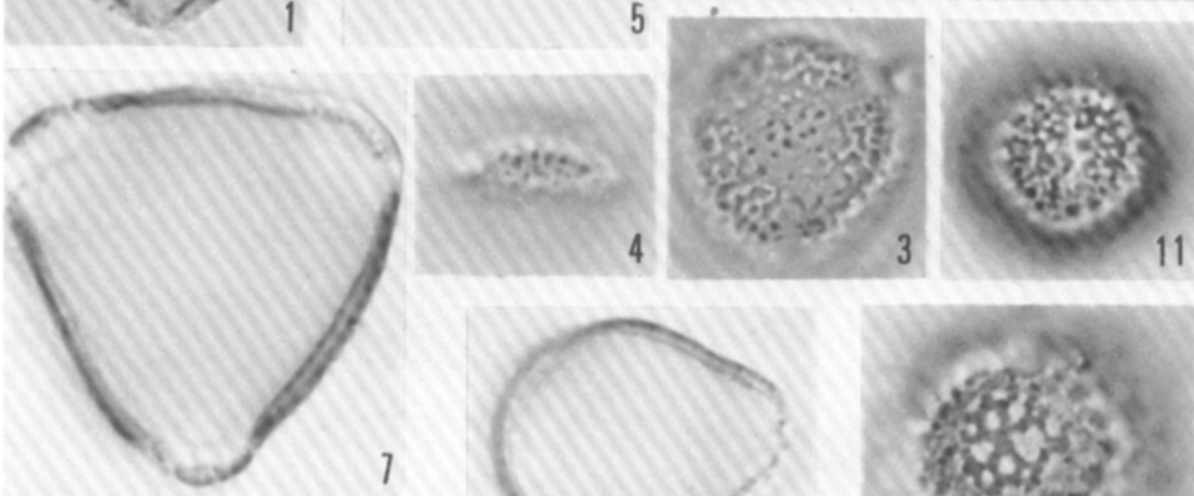

$\infty$

4
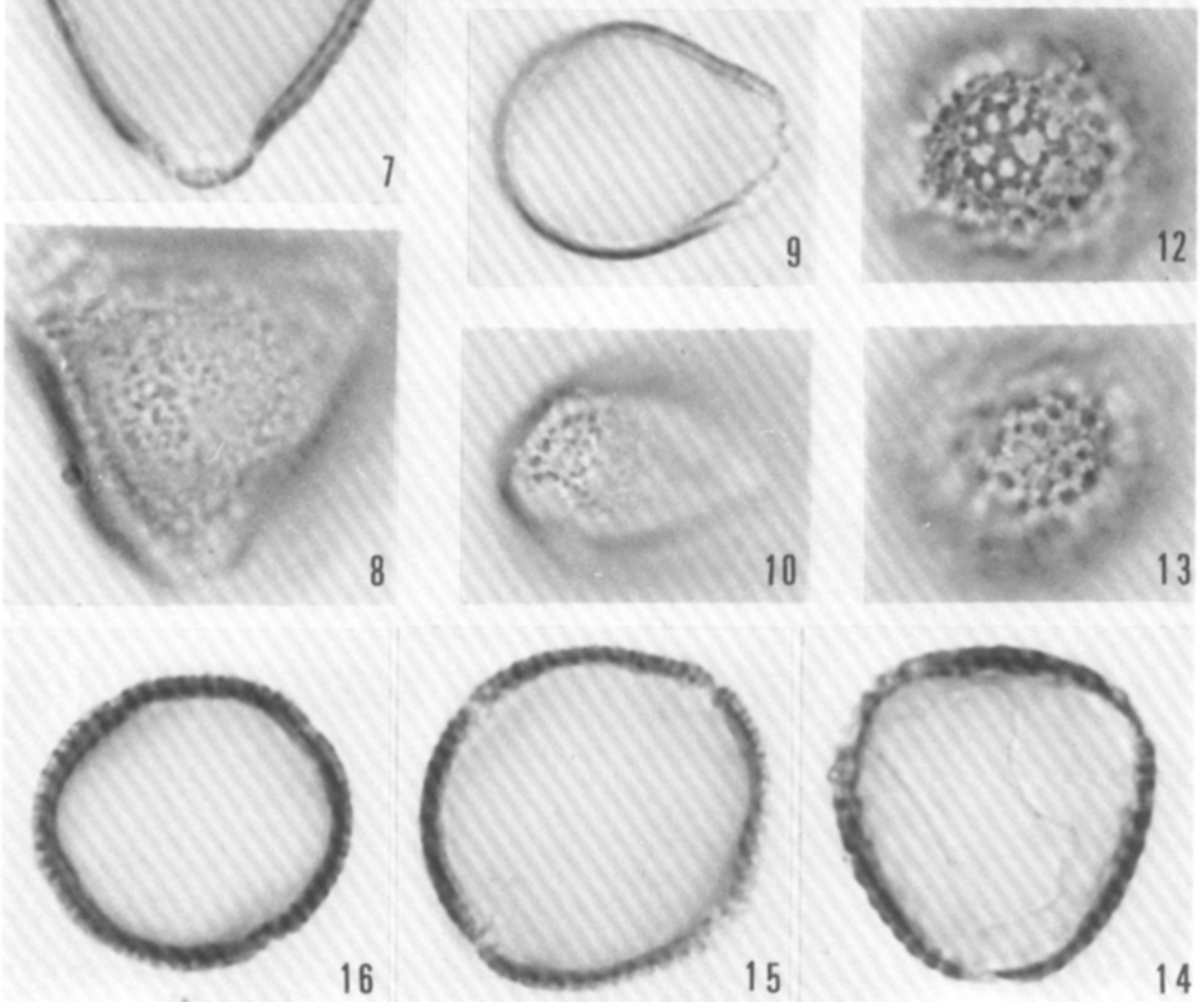


\section{PLATE XIII}
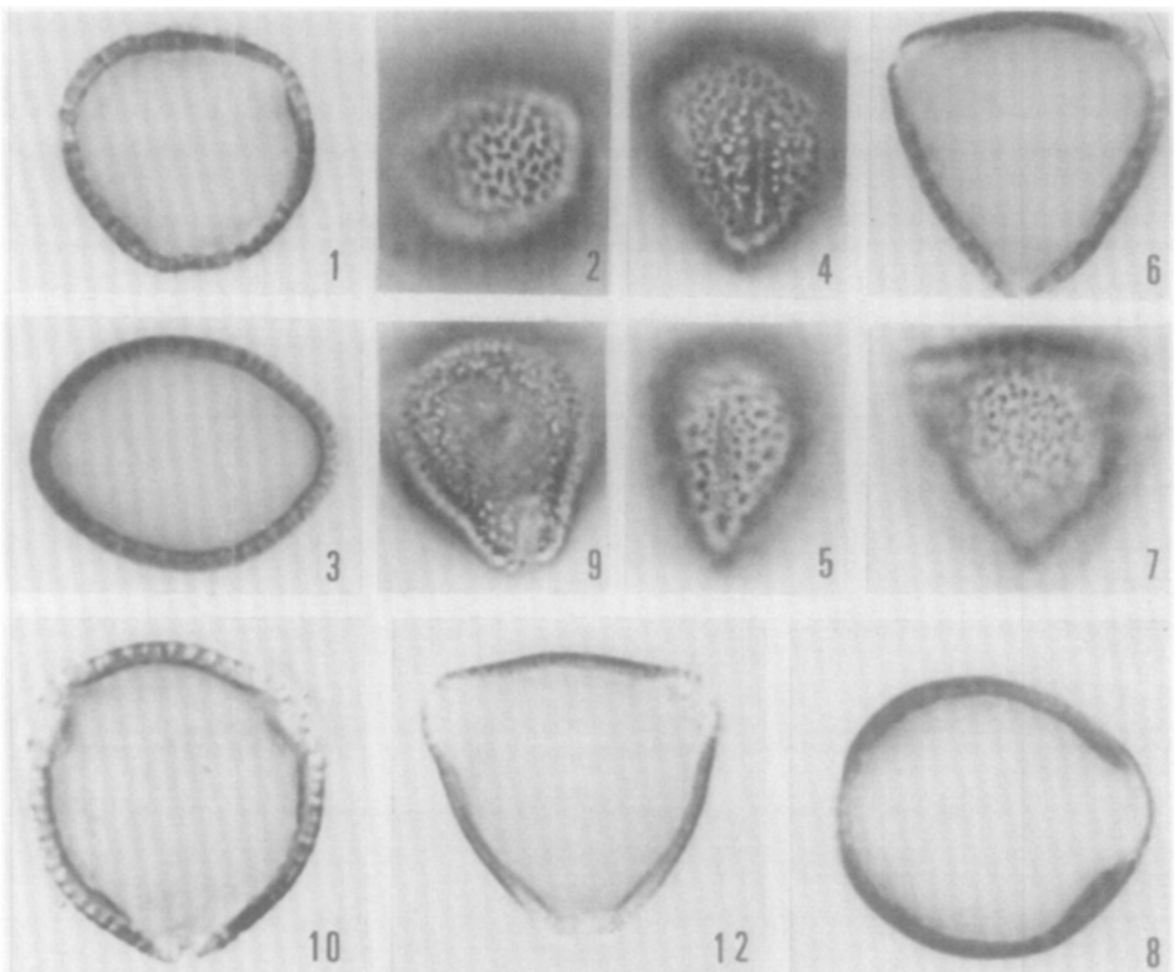

5

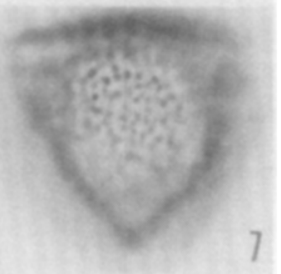

10

12
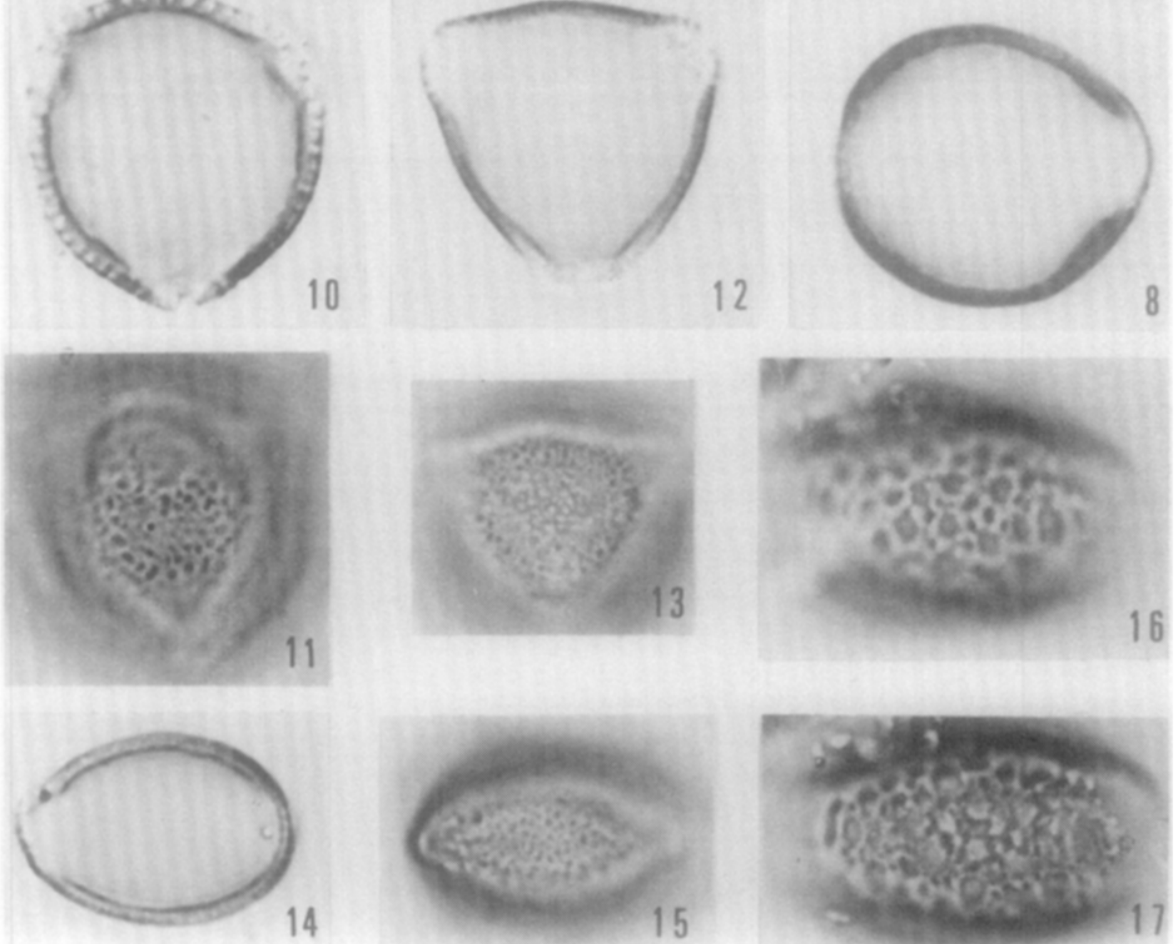


\section{PLATE XIV}
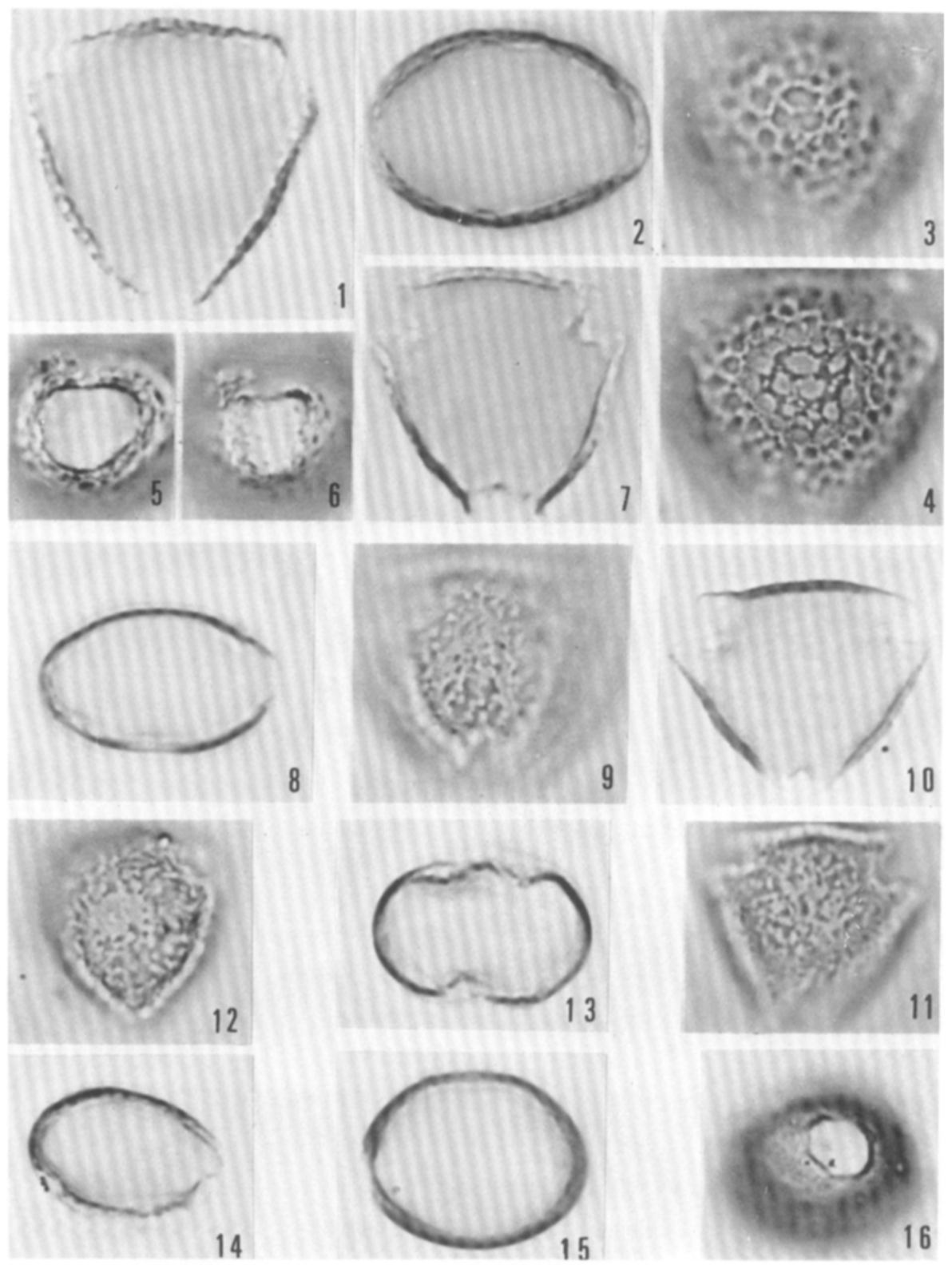
4. Rather long, narrow colpus with more or less distinct margins.

5. Colpus at high focus.

6. Polar view; optical cross-section; sides slightly convex; angles subacute.

7. Polar view; microreticulate ornamentation at high focus.

8. Equatorial view; optical cross-section; elliptic outline.

D. rugosum (Vahl) Prance (Froes 30175 )

9. Ectocolpus, short, narrow and with acute ends.

12. Fquatorial view; optical cross-section; protruding apertures.

13. Polar view; tectum perforatum.

14. Equatorial view; optical cross-section; elliptic outline.

15. Equatorial view; tectum perforatum.

D. spruceanum Baillon (Cuatrecasas 8975)

10. Polar view; optical cross-section; apertures not or only slightly protruding.

1. Polar view; microreticulate ornamentation.

D. thollonii Pellegrin (Thollon $512 \mathrm{~b}$ )

16. Equatorial view; coarse reticulum at high focus; Iumina irregular in ou tline.

17. Equatorial view; ornamentation in low focus; muri slightly thicker below.

PI.ATE XIV ( $\times 2000 ;$ p.86)

\section{D. thollonii Pellegrin (Thollon $512 \mathrm{~b}$ )}

1. Polar view; optical cross-section; sexine about as thick as nexine.

2. Equatorial view; optical cross-section; elliptic outline.

3. Polar view; coarse reticulum at high focus; muri not or only slightly interrupted.

4. Ornamentation at low focus; muri thicker below.

5. Endoaperture, distinct, large, more or less circular, porus.

6. Endocolpus, short and rather broad.

D. madagascariense Poiret ssp. madagascariense (Gilbert 2170)

7. Polar view; optical cross-section; short, broad colpi.

8. Equatorial view; elliptic outline; sexine thinner than nexine.

9. Polar view; ornamentation at apocolpium; muri interrupted, thicker below.

D. madagascariense Poiret var. beniense (Engler) Breteler (Mildbread 2200)

10. Polar view; optical cross-section; sexine thinner than nexine; colpi short and broad.

11. Polar view; ornamentation at low focus; muri interrupted and thicker below.

D. madagascariense Poiret var. madagascariense

12. Ornamentation at apocolpium (Verdcourt 1899, Kenya).

13. Equatorial view; distinct sunken poles (Perrier de la Bâthie 408, Madagascar).

1.1. Equatorial view; optical cross-section (Verdcourt 1899, Kenya).

15. Equatorial view; optical cross-section (Le Testu s.n., Rép. Centre-Afrique).

16. Endoaperture, small and circular (Ie Testu s.n., Rép. Centre-Afrique).

PLATE XV ( $\times 2000 ;$ p.89)

\section{D. madagascariense Poiret var. madagascariense}

1. Polar vicw; optical cross-section (Cons. Rés. Nat. Madagascar 7366, Madagascar).

2. Polar view; optical cross-section (Le Testu s.n., Rép. Centre-Afrique).

3. Polar view; optical cross-section (Pierlot 3153, Zaire).

4. Polar view; optical cross-section (Verdcourt 1899, Kenya).

5. Equatorial view; colpus (Perrier de la Bâthie 408, Madagascar).

6. Equatorial view; ornamentation; muri continuous (Pierlot 3153, Zaire).

7. Polar view; ornamentation (Le Testu s.n., Rép. Centre-Afrique).

8. Polar view; ornamentation at low focus (Pierlot 3153, Zaire).

9. Polar view; ornamentation at high focus (Pierlot 3153, 7aire).

D. limoriense (Decandolle) Boerlage (figs.10-12: Griffith 2170; figs.13-15: Ahern's Coll. 3157) 
10. Polar view; optical cross-section; pollen grain without endoapertures; outline nearly sexangular.

11. Equatorial view; optical cross-section; sunken poles.

12. Microreticulate ornamentation.

13. Polar view; optical cross-section; distinct endoapertures; angles obtuse.

14. Polar view; microreticulate ornamentation; sunken poles; muri thicker below.

15. Equatorial view; optical cross-section; sunken poles.

PLA'TE XVI $(\times 2000 ;$ p.90)

1). zenkeri Engler (figs. 1-4: Bos 6249; figs. 5-9: Talbot 1631; fig.7: Le T'estu 8526)

1. Polar view; optical cross-section of inaperturate grain.

2. Polar view; coarse reticulum at high focus.

3. Ornamentation at low focus.

4. Equatorial view; optical cross-section; elliptic outline.

5. Polar view; optical cross-section.

6. Polar view; coarse reticulum; muri distinctly interrupted.

8. Endoaperture; small, circular endoporus.

9. Endoaperture; small, slightly lalongate endoporus; very short and narrow ectocolpus faintly visible.

7. Polar view; ornamentation at high focus; reticulum fine.

Tapura lanceolata (Ducke) Rizzini (Ducke 325)

10. Polar view; optical cross-section: sides distinctly convex.

11. Equatorial view; optical cross-section; elliptic outline.

Tapura amazonica Poeppig et Endlicher (Black 55-18219)

12. Equatorial view; fastigium.

13. Polar view; optical cross-section; sides distinctly convex.

14. Polar view; optical cross-section.

15. Equatorial view; narrow colpus and rather broad, indistinet endoaperture.

16. Mesocolpium; microreticulate ornamentation.

17. Polar view; colpus ends.

Tapura fischeri Engler (Volkens 2170)

18. Apocolpium; microreticulate ornamentation; lumina slightly larger in size than in mesocolpium.

19. Polar view; optical cross-section; sides nearly straight.

20. Equatorial view; optical cross-section.

21. Ectocolpus, narrow and with irregular margins; endoaperture indistinct.

22. Domed sexine in equatorial plane.

PLATE XVII (X 2000; p.91)

Tapura bouquetiana Hallé et Heine (Breteler 5740 )

1. Polar view; optical cross-section; sides straight to slightly concave; angles obtuse.

2. Microreticulate to tectate ornamentation at high focus.

3. Ornamentation at low focus.

4. Equatorial view; optical cross-section; thick exine; rectangular outline; distinct fastigium and faint costae.

5. Ectocolpus; rather long, very narrow and with irregular margins.

6. Ectocolpus.

7. Endoporus; outline rectangular, slightly lolongate.

Tapura coriacea Macbride (Klug 586)

8. Equatorial view; optical cross-section.

9. Polar view; optical cross-section; outline circular.

10. Ectocolpus; narrow, long and with irregular margins; ectocolpus narrow and indistinct. 


\section{PLATE XV}

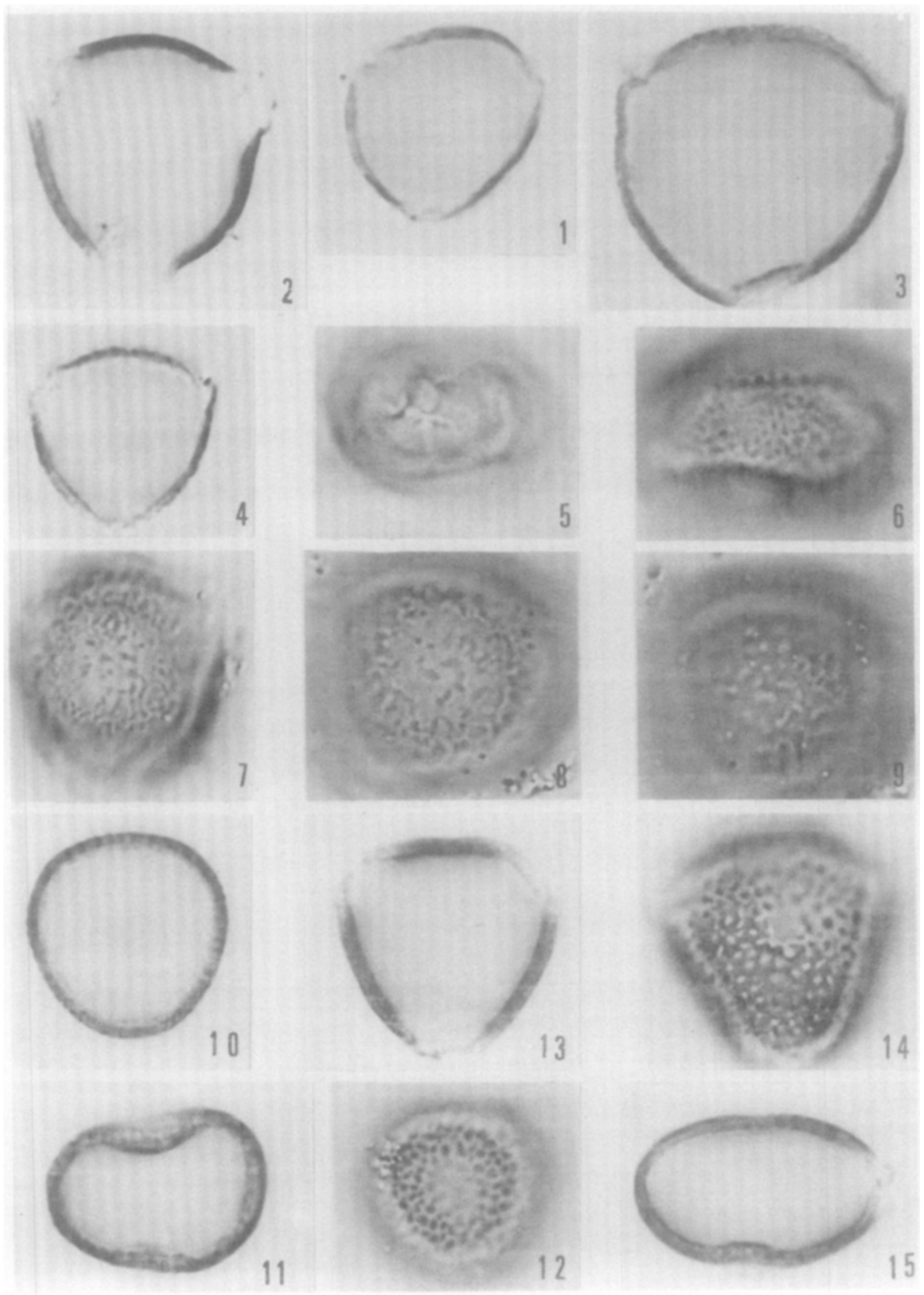




\section{PLATE XVI}

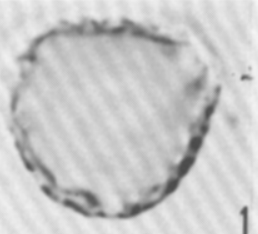

1

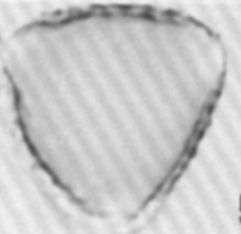

5

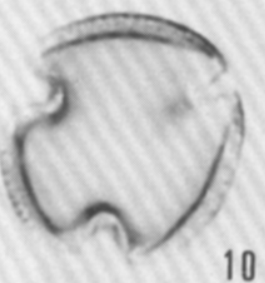

10

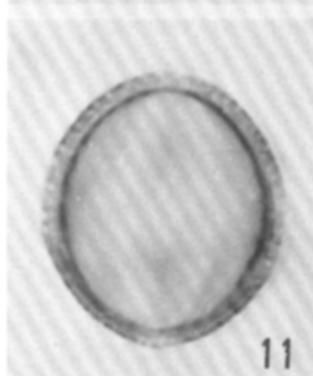

11

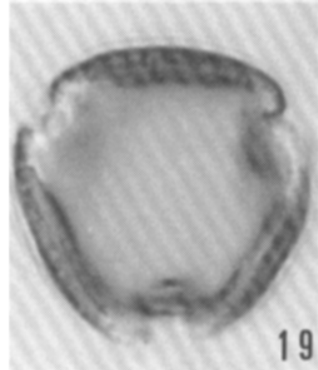

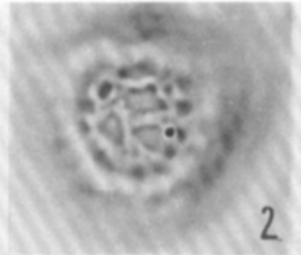
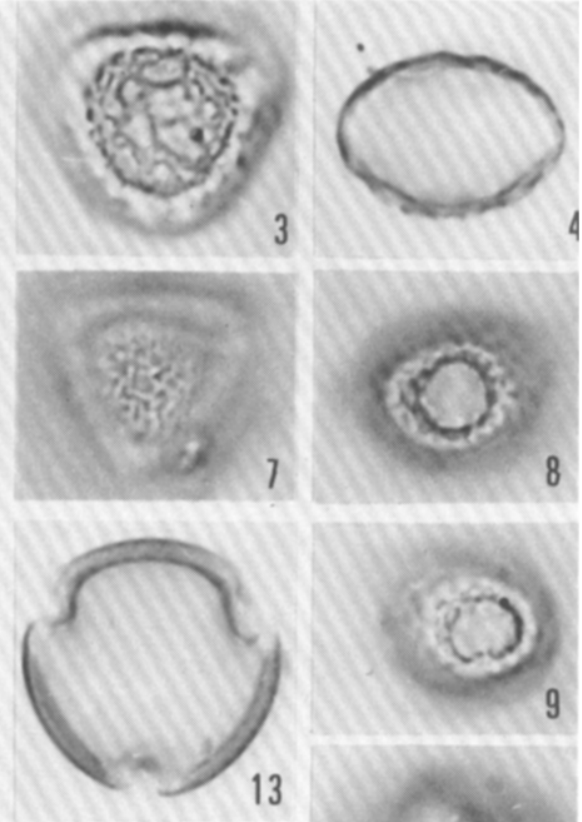

13

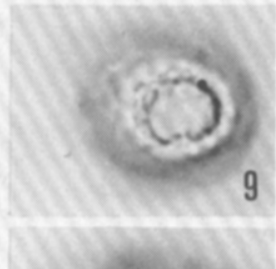

12
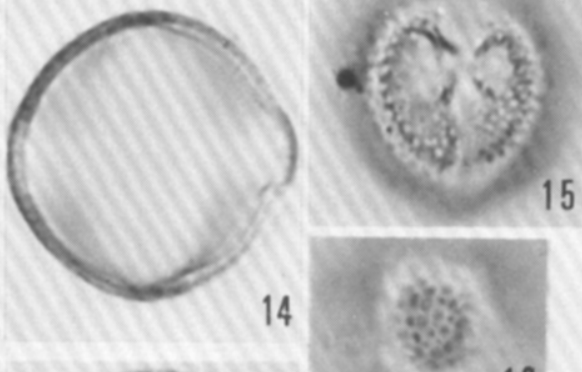

18
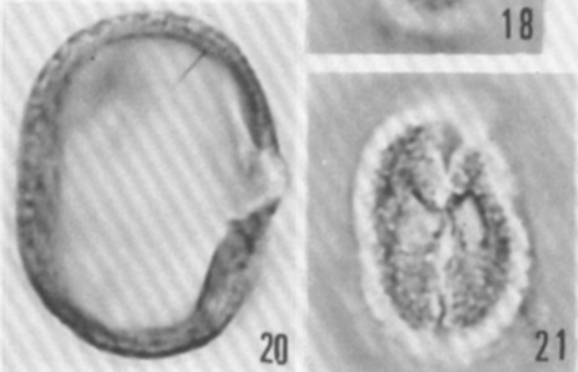

21

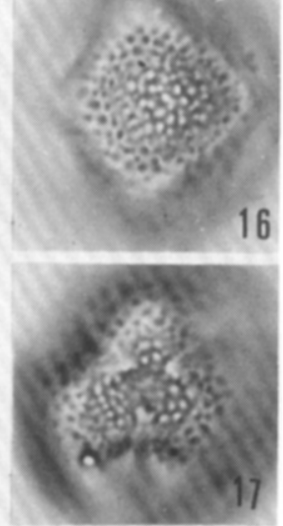

16

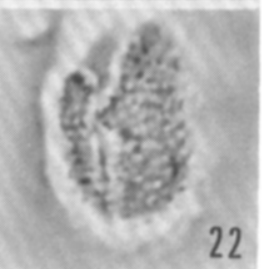




\section{PLATE XVII}

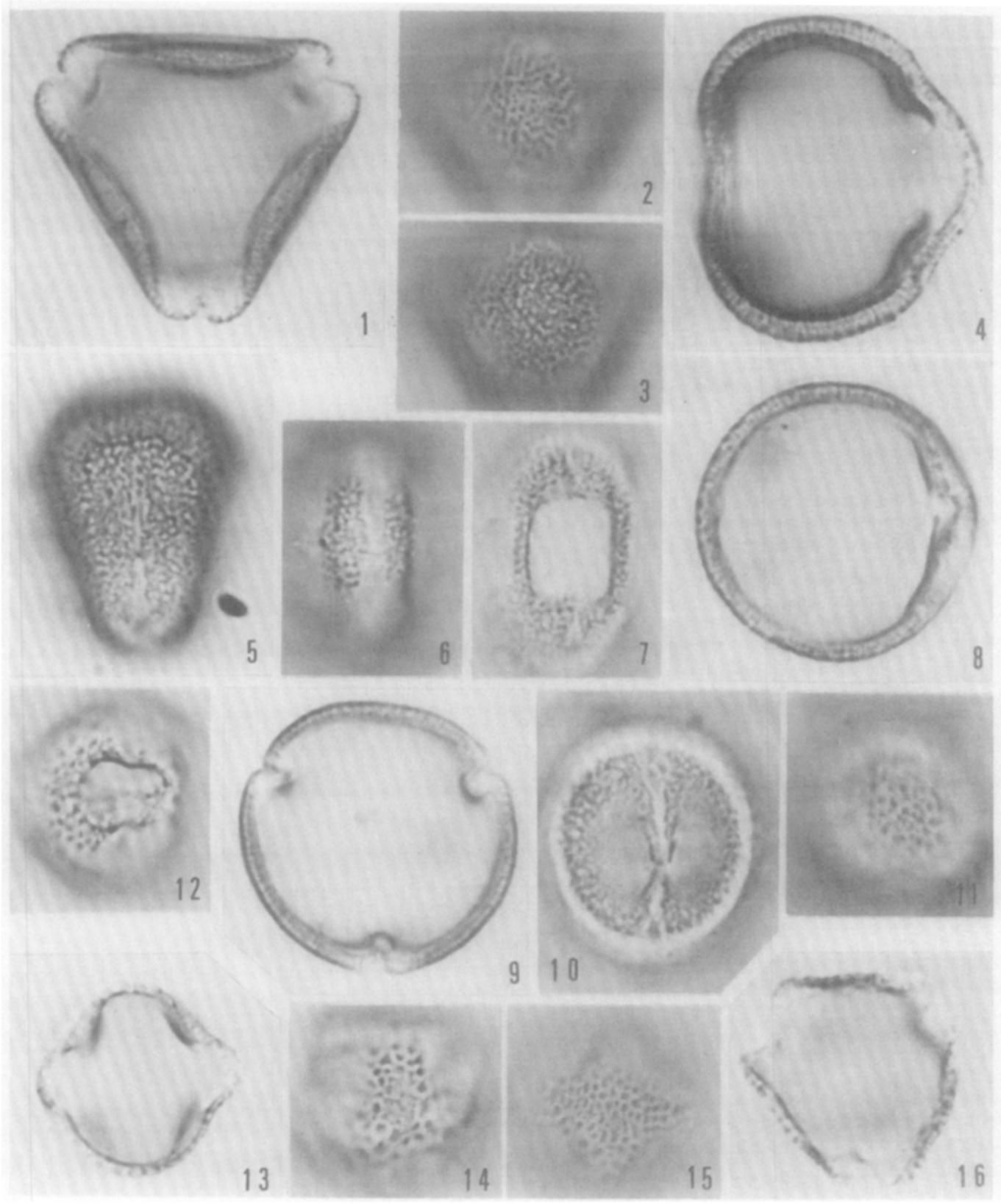




\section{PLATE XVIII}
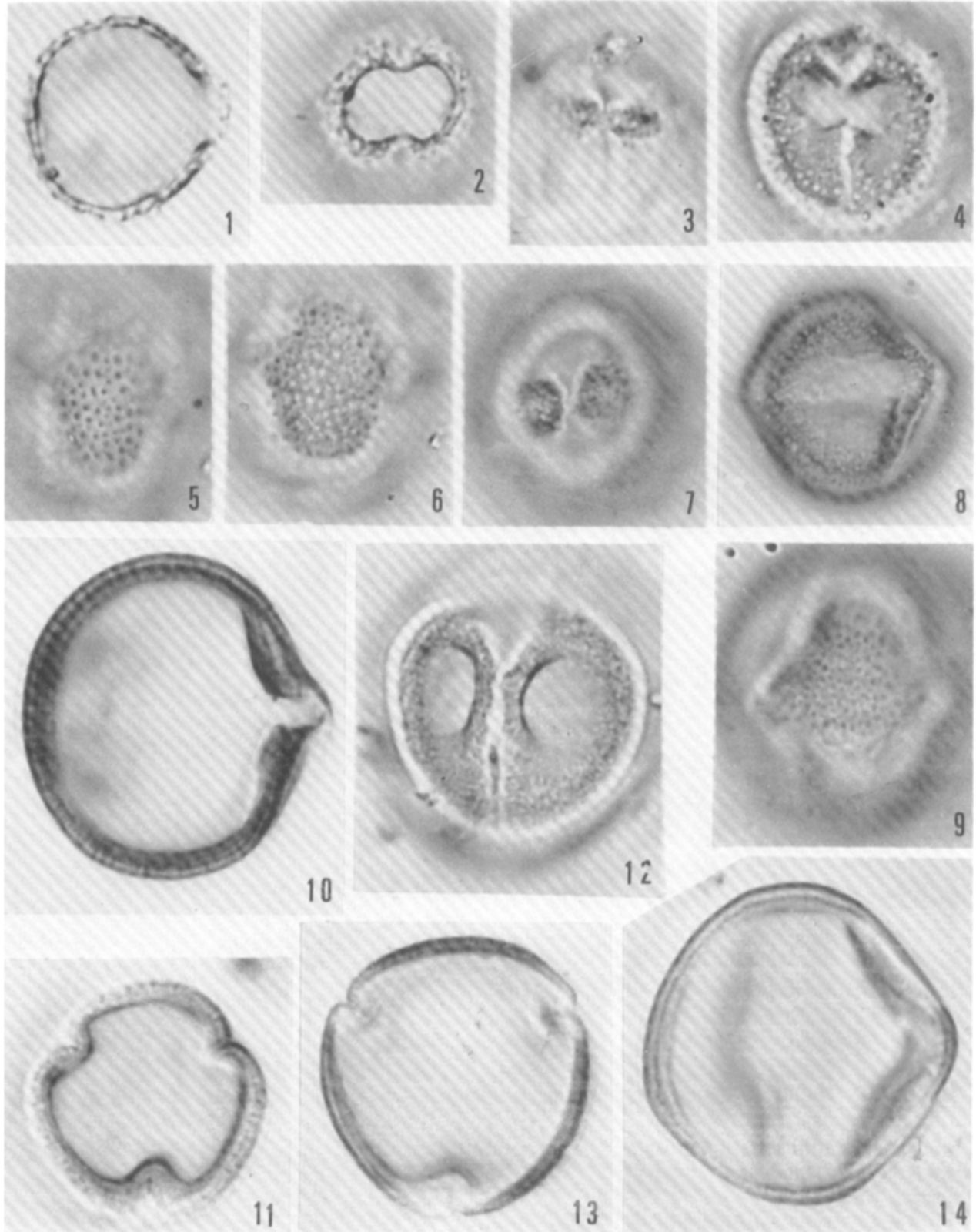
11. Microreticulate ornamentation.

Tapura ivorensis Breteler (Breteler 5955)

12. Endoaperture, lalongate, with faint costae.

13. Equatorial view; optical cross-section; distinct fastigium.

14. Ornamentation at apocolpium; lumina larger in size than in mesocolpium.

15. Ornamentation at mesocolpium; microreticulum.

16. Polar view; optical cross-section; sides straight.

PLATE XVIII ( $\times 2000 ;$ p.92)

Tapura ivorensis Breteler (Breteler 5955)

1. Equatorial view; optical cross-section.

2. Endoaperture; more or less rectangular in outline.

Tapura juliani Macbride (Klug 2010)

3 . Bridge overlaying the ectocolpus.

4. Endoaperture; rather broad.

5. Ornamentation at high focus; tectum perforatum.

6. Ornamentation at low focus.

10. Equatorial view; optical cross-section; fastigium and faint costae.

11. Polar view; optical cross-section.

Stephanopodium blanchetianum Baillon (Bondar 2459)

7. Narrow colpus; domed sexine parts of the fastigium just not connected into a bridge.

8. Equatorial view; endocingulus.

9. Mesocolpium; microreticulate ornamentation.

13. Polar view; optical cross-section; more or less circular in outline.

Stephanopodium engleri Baillon (Sch wacke 13386)

12. Ectocolpus; fastigium and endoaperture.

14. Equatorial view; optical cross-section.

PLATE XIX (X 3500;p.94)

Scanning electron micrographs

1. Dichapetalum pallidum (Olivier) Engler; polar view (Leeuwenberg 4549).

2. D. pallidum (Olivier) Engler; equatorial view (Leeuwenberg 4549).

3. D. timoriense (Decandolle) Boerlage; inaperturate pollen grain (Java, s.c., s.n.).

4. D. bangii (F. Didrichs) Engler; equatorial view (Zenker 1384).

5. D. zenkeri Engler; polar view (Le Testu 7228).

6. Tapura fischeri Engler; polar view (Geerlings and Bokdam 2538).

\section{PLATE XX (p.95)}

Scanning electron micrographs

1. Dichapetalum arenarium Breteler; polar view (Hensen 486) (x 3500).

2. D. angolense Chodat; polar view (Dinklage 1970) (x 3500).

3. D. heudelotii (Planchon ex Olivier) Baillon; polar view (Leeuwenberg 7906) (x 4500).

4. D. acuminatum De Wildeman; polar view (Louis 10588) (x 3000).

5. Tapura bouquetiana Hallé et Heine; equatorial view (Breteler 5740$)(\times 2700)$.

6. Dichapetalum madagascariense Poiret; polar view (Donis 1966) (x 3500). 


\section{PLATE XIX}
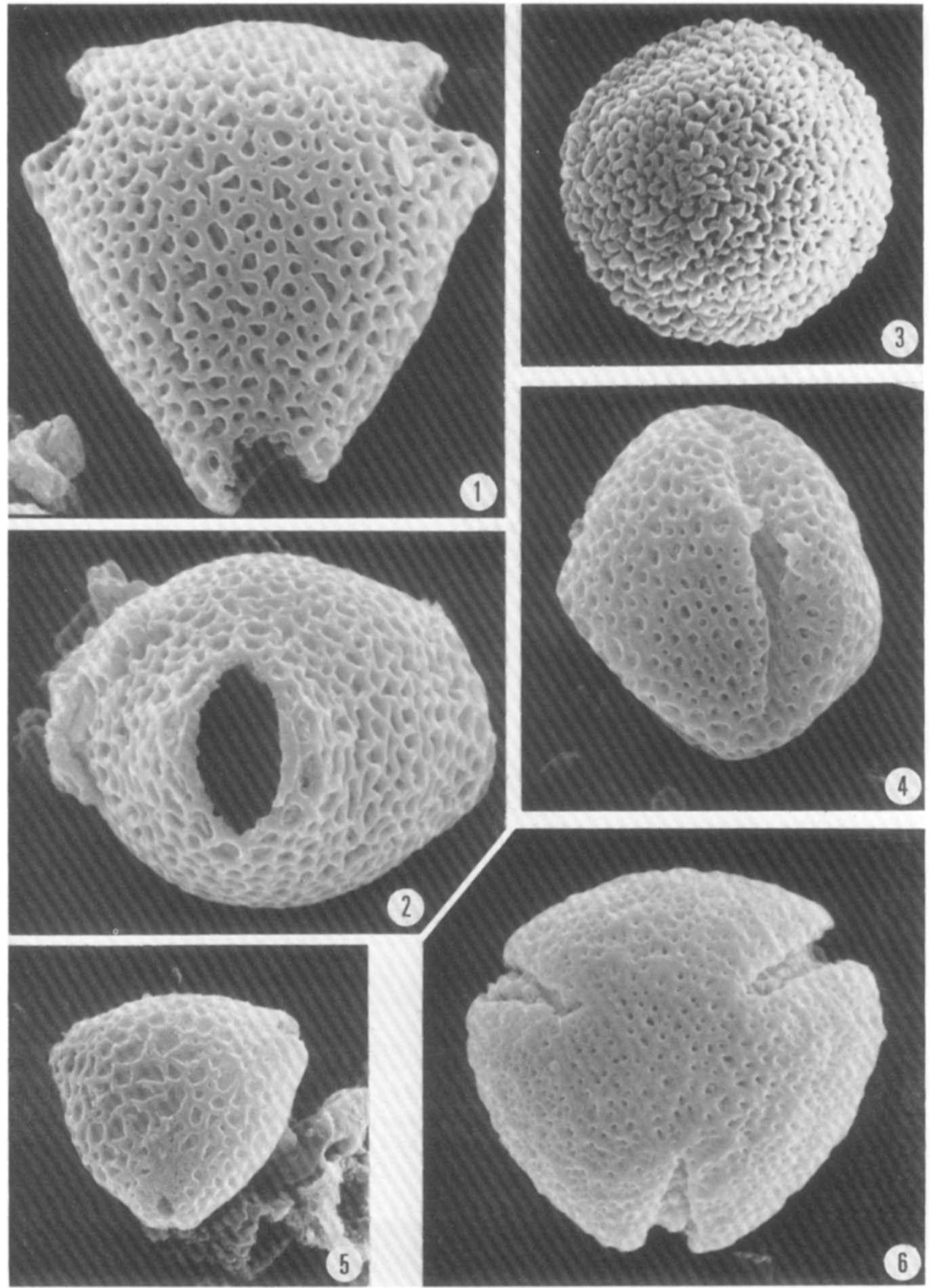

6 


\section{PLATE XX}

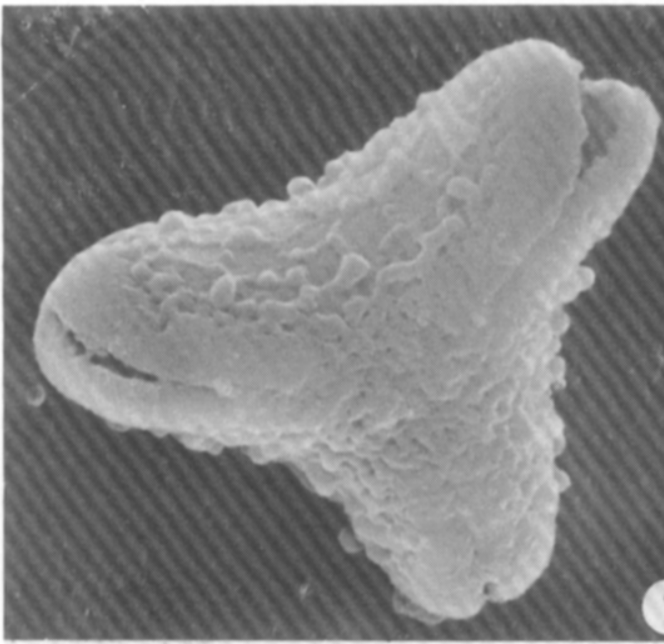

(1)

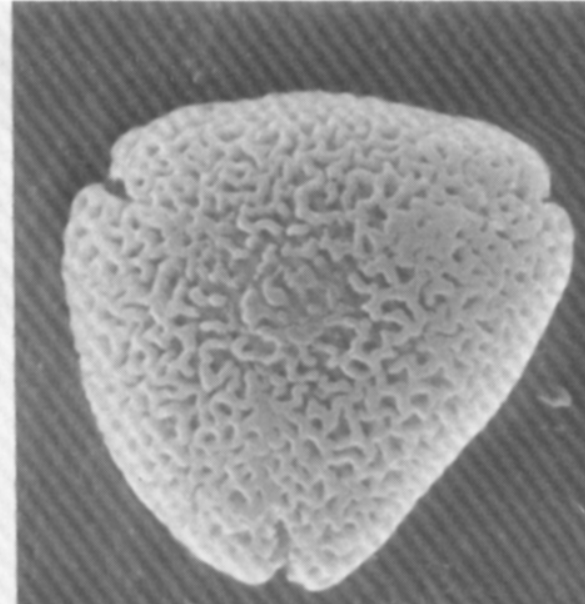

(2)
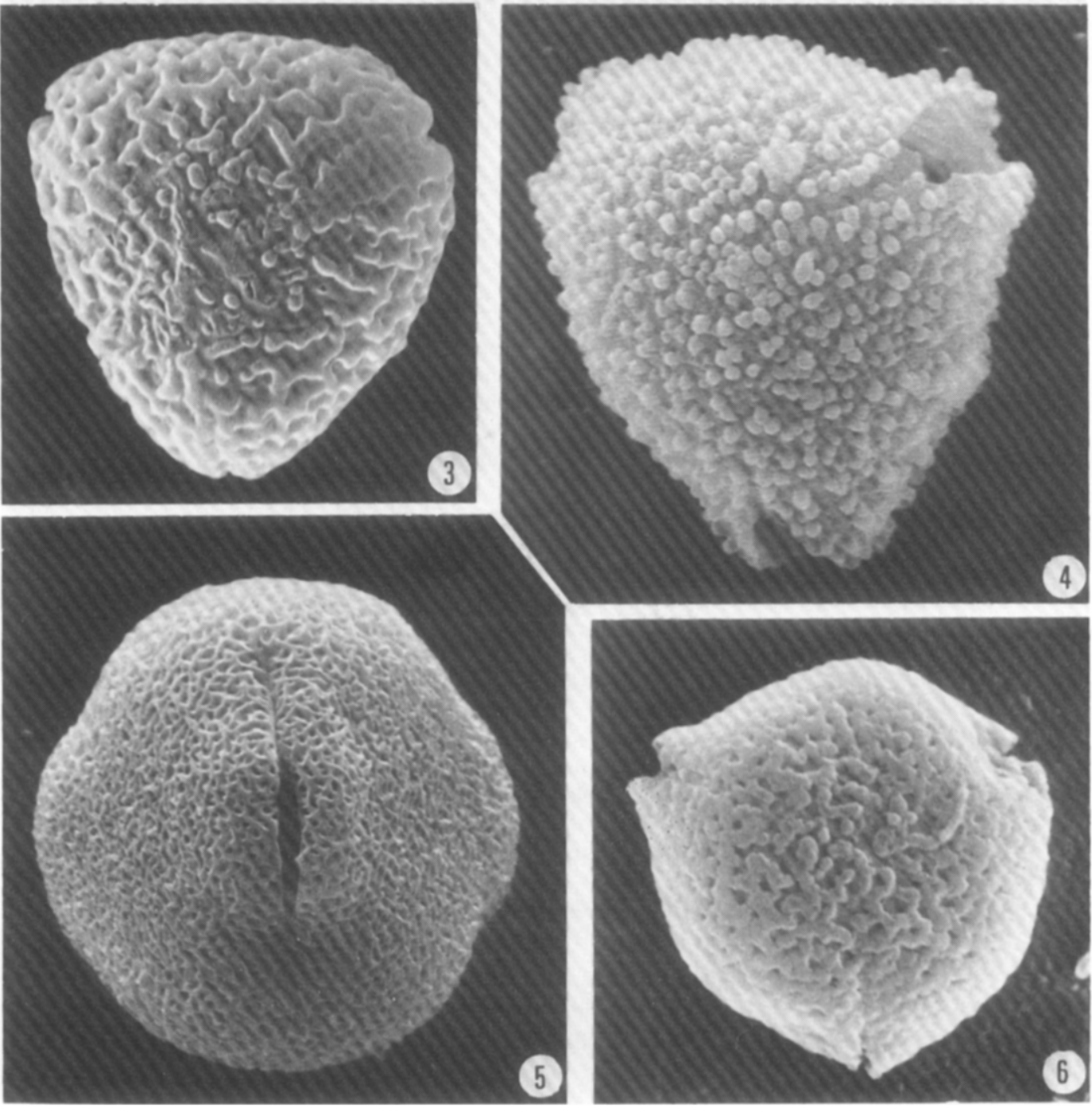


\section{REFERENCES}

Archangelsky, D. B., 1971. Palynotaxonomy on the Thymeleaceae s.1. In: L. A. Kupryanova and M. S. Jakovlev (Editors), Pollen Morphology. The Academy of Sciences of the U.S.S.R., Komarov Botanical Institute, Moscow, pp.104-234.

Breteler, F. J., 1973. The African Dichapetalaceae. A taxonomical revision. Meded. Landbou whogeschool Wageningen, 73-13: $124 \mathrm{pp}$.

Descoings, B., 1961. In: Humbert, Flore de Madagascar et des comores. 110e familie Dichapetalacées. Paris, $38 \mathrm{pp}$.

Erdtman, G., 1952. Pollen Morphology and Plant Taxonomy. Angiosperms. Almquist and Wiksell, Stockholm, 539 pp.

Germeraad, J. H., Hopping, C. A. and Muller, J., 1968. Palynology of Tertiary sediments from tropical areas. Rev. Palaeobot. Palynol., 6: 189-348.

Hallé, N. et Heine, H., 1967. Deux nouvelles espèces Africaines du genre Tapura Aubl. (Dichapetalaceae). Adansonia, Ser. 2, 7: 43-51.

Leenhouts, P. W., 1956. Dichapetalaceae. Flora Malesiana, ser. 1, 5: 305-316.

Leenhouts, W., 1957. Florae Malesianae Praecursores, XII. Some notes on the genus Dichapetalum (Dichapetalaceae) in Asia, Australia, and Malesia. Reinwardtia, 4: 75-87.

Leins, P., 1968. Eine einfache Methode zur Herstellung von Schnitten durch azetolysierte Pollenkörner. Grana Palynol., 8: 252-254.

Lobreau, D., 1967. Contribution à l'étude du pollen des Malpighiaceae d'Afrique. Pollen Spores, 9: 241-277.

Lobreau, D., 1969. Les limites de l'ordre des Celastrales d'après le pollen. Pollen Spores, 11: 499-555.

Muller, J., 1970a, Palynological evidence on early differentiation of angiospermes. Biol. Rev., 45: 417-450.

Muller, J., 1970b. Pollen Morphology of the genus Lepisanthes (Sapindaceae) in relation to its taxonomy. Blumea, 18: 507-561.

Nair, P. K. K., 1966. Trends in the morphological evolution of pollen and spores. J. Indian Bot. Soc., 44: 468-478.

Prance, G. T., 1972. A monograph of the neotropical Dichapetalaceae. Flora Neotropica, 10.

Punt, W., 1962. Pollen Morphology of the Euphorbiaceae with special reference to taxonomy. Wentia, 7: 1-116.

Punt, W., 1967. Pollen Morphology of the genus Phyllanthus (Euphorbiaceae). Rev. Palaeobot. Palynol., 3: 141-150.

Punt, W., 1968. Pollen Morphology of the American species of the subfamily Costoideae (Zingiberaceae). Rev. Palaeobot. Palynol., 7: 31-43.

Punt, W., 1971. Pollen Morphology of the genera Norantea, Souroubea and Ruyschia (Marcgraviaceae). Pollen Spores, 13: 199-232.

Punt, W. and Leenhouts, P., 1967. Pollen Morphology and taxonomy in the Loganiaceae Grana Palynol., 7: 469-516.

Reitsma, Tj., 1969. Size modifications of recent pollen grains under different treatments. Rev. Palaeobot. Palynol., 9: 175-202.

Reitsma, Tj., 1970a. Suggestions towards unification of descriptive terminology of Angiosperm pollen grains. Rev. Palaeobot. Palynol., 10:39-60.

Reitsma, Tj., 1970b. Pollen Morphology of the Allangiaceae. Rev. Palaeobot. Palynol., 10: 249-332.

Smit, P. G. and Punt, W., 1969. Taxonomy and pollen morphology of the Caltha leptosepala complex. Proc. K. Ned. Akad. Wet., Amsterdam, Ser. C, 72(1): 16-27.

Van Campo, M., 1966. Pollen et phylogénie des Bréviaxes. Pollen Spores, 8: 57-73.

Thanikaimoni, G. 1968. Morphologie des pollens des Ménispermacées. Trav. Sect. Sci. Techn. (Pondichéry), 5 (4): 57 pp. 
Thanikaimoni, G., 1971. Les Palmiers: Palynologie et Systêmatique. Thèse Université de Montpellier, Faculté des Sciences. Institut Français de Pondichëry, India.

Vishnu-Mittre, 1964. Contemporary thought in Palynology. Phytomorphology, 14: 135-147.

Walker, J. W., 1971. Pollen Morphology, phytogeography and phylogeny of the Annonaceae. Contrib. Gray Herb., 202: 1-131. 